\title{
LA LEGITIMACIÓN PARA EL PAGO DE UN TERCERO
}

["Legal Standing for the Payment of a Third Party"]

\author{
Claudia Serrano Herrera* \\ Universidad de los Andes, Santiago de Chile
}

\begin{abstract}
RESUMEN
El artículo estudia el pago hecho por quien no es deudor o no es deudor exclusivo, en aras a determinar de qué manera se concilian intereses tan diversos como los del acreedor, deudor y solvens, desde dos puntos de vista: la amplitud de la legitimación del tercero y su intensidad, es decir, hasta qué punto al tercero le es lícito perseverar en su pretensión de cumplimiento imponiendo el pago. Por último, se analizan los efectos del pago, a fin de precisar el contenido y límites de los derechos de reembolso y subrogación, así como el modo en que se integran unos y otros.
\end{abstract}

\section{Palabras Clave}

Pago - Cumplimiento - Pago de tercero - Derecho de reembolso - Subrogación.

\section{Abstract}

This article analyses the payment carried out by someone who is not the debtor or the exclusive debtor in order to determine how such diverse interests - as those of the creditor, debtor and solvens - are conciliated from two stand points: the extent and the intensity of the legal standing of the third party, that is, to what extent it is legal for the third party to persevere in their compliance claim by imposing the payment. Finally, the payment effects are analyzed in order to determine the content and limits of the reimbursement and subrogation rights, as well as the manner in which they are integrated.

\section{KEYWORDS}

Payment - Fulfillment - Payment to third parties - Reimbursement right - Subrogation.

[RECIBIDo el 22 de agosto y ACEPTADo el 5 de diciembre de 2011].

* Licenciada en Ciencias Jurídicas y Sociales de la Universidad de Chile. Profesora de la Facultad de Derecho de la Universidad de los Andes. Dirección postal: Avenida San Carlos de Apoquindo No 2.200, Las Condes, Santiago, Chile. Correo electrónico: cserrano@uandes.cl 


\section{EL CUMPLIMIENTO O PAGO EN GENERAL}

El Código Civil ${ }^{1}$, al igual que todos los códigos de los diversos sistemas jurídicos, considera fenómenos de naturaleza extintiva de las relaciones obligatorias. Ello es así por cuanto la obligación misma está esencialmente destinada a extinguirse ${ }^{2}$. No se concibe una obligación que esté llamada a perdurar en el tiempo por cuanto ella importa a la vez que una situación activa, de crédito, una de sumisión o de deber jurídico y en este aspecto, limitativa de la libertad del hombre 3 . Esta idea de la temporalidad de la obligación queda bien expresada en palabras de Radbruch, en cuanto la obligación lleva en sí misma el germen de su propia muerte, desaparece en el momento en que alcanza el cumplimiento de su fin ${ }^{4}$, lo que permite concluir que el primer efecto, el normal, de la obligación, es el de su cumplimiento o pagos.

La casi totalidad de la doctrina identifica el cumplimiento de la obligación con el pago de la misma ${ }^{6}$. Pese a que el Código Civil, como todos los tributarios del Code Civil francés, regulan el pago en el capítulo dedicado a la extinción de las obligaciones, lo cierto es que de la propia definición de pago del artículo 1568, aparece con claridad que "pago" se refiere al cumplimiento de la obligación: la prestación de lo que se debe 7 . Esta es la conducta correcta, que

${ }^{1}$ Las referencias a "el Código" o a algún artículo sin indicación del texto legal al que pertenece deben entenderse relativas al Código Civil chileno. Asimismo, la abreviatura "CC.".

${ }^{2}$ Cfr. Dítz-PICAzo, Luis, Fundamentos del Derecho civil patrimonial, II: Las relaciones obligatorias ( $6^{a}$ edición, Madrid, Thomson-Civitas, 2008), p. 153, quien da cuenta de las diversas teorías acerca de la relación jurídica obligatoria, como órgano y como proceso, pero ambas coinciden en que la obligación está encaminada a alcanzar un fin determinado y a extinguirse con la obtención de ese fin, por lo que su naturaleza es puramente transitoria.

${ }^{3}$ Hernández-Gil, Antonio, Derecho de obligaciones (Madrid, Maribel Artes Gráficas, 1960), pp. 60-61. Véase también: Giorgianni, Michele, La obligación. La parte general de las obligaciones (trad. Verdera y Tuells, Evelio, Barcelona, Bosch Casa Editorial, 1958), pp. 139-142.

${ }^{4}$ Radbruch, Gustav, Filosofía del Derecho (trad. J. Medina Echevarría, Granada, Comares, 1999), p. 183.

${ }^{5}$ Cfr. Lasarte, Carlos, Derecho de obligaciones. Principios de Derecho civil (Madrid, Marcial Pons, 2007), II, pp. 121 y 122, para quien este efecto del cumplimiento deja en evidencia que toda obligación concluye su ciclo vital una vez satisfecho el interés del acreedor.

${ }^{6}$ Salvo algunos autores que ven al pago como el momento final del cumplimiento, siendo este un estadio mucho más amplio en la vida de la obligación. Véase: Puig PEÑA, Federico, Tratado de Derecho civil español (Madrid, Ed. Revista de Derecho Privado, 1946), IV, 1, pp. 158 y 160.

${ }^{7}$ Véase: Abeliuk Manasevich, René, Las obligaciones (4a edición, Santiago, Edi- 
debe quedar precisada antes que las virtualidades de la conducta incorrecta o incumplimiento ${ }^{8}$. Por otra parte, el cumplimiento de la obligación, que constituye el pago de la misma, trae aparejado que la obligación se extinga, pero ello no es más que una consecuencia de haberse satisfecho íntegramente el interés del acreedor mediante la conducta debida?

La extinción de la obligación no es el único efecto del cumplimiento y tampoco lo es siempre de un modo absoluto, ya que no todo pago importa dicho efecto, v. gr. cuando paga un tercero por cuenta del deudor, habiendo lugar a la subrogación, la deuda subsiste entre el tercero que paga y el deudor, de modo que el efecto extintivo resulta parcial y relativo por cuanto sólo se produce respecto del acreedor. Puede decirse que lo efectivamente consustancial al pago es la satisfacción del acreedor ${ }^{10}$, pese a que el pago al acreedor aparente extingue la deuda y libera al deudor, pero no satisface al acreedor. Del propio significado etimológico de "pagar", en latín pacare: "apaciguar, pacificar" al acreedor, el resultado mira hacia el interés satisfecho del acree-

torial Jurídica de Chile, 2005), II, p. 533, para quien, en todo caso, se trata de un mero problema de método y claridad en el enfoque de la institución.

${ }^{8}$ El estudio del efecto de las obligaciones se ha referido, tradicionalmente, a aquél momento en la dinámica de la obligación en que se produce un quiebre en la relación obligatoria, el estadio de incumplimiento, y no se aborda el fenómeno normal del cumplimiento. Es por ello que los tópicos que comprende miran más bien al elemento responsabilidad dentro de la estructura de la obligación, con énfasis en los mecanismos o instrumentos de tutela del acreedor, dejando de lado, todo cuanto dice relación con el elemento deuda, que se refiere precisamente al contenido prestacional de la obligación. Por todos: Vial del Río, Víctor, Manual de las obligaciones en el Código Civil chileno (2a edición, Santiago, Editorial Biblioteca Americana, 2007), pp. 225-226.

${ }^{9}$ Cfr. Fueyo Laneri, Fernando, Cumplimiento e incumplimiento de las obligaciones ( $3^{a}$ edición actualizada, Santiago, Editorial Jurídica de Chile, 2004), pp. 49-52; Vidal Olivares, Álvaro, La construcción de la regla contractual en el derecho civil de los contratos, en Revista de Derecho de la Pontificia Universidad Católica de Valparaíso, 21 (2000), pp. 209-212; EL MISmo, Cumplimiento e incumplimiento contractual en el Código Civil. Una perspectiva más realista, en Revista Chilena de Derecho, 34 (2007) 1, pp. 42-44; Díez-Picazo, Luis, cit. (n. 2), pp. 270-271 y 585-586.

${ }^{10}$ No obstante, existen autores que critican esta valoración y por ello ven en el pago del tercero y en otras modalidades de pago no un verdadero acto solutorio sino un acto satisfactorio, denunciando un excesivo enfoque del cumplimiento en el interés del acreedor, Véase Pascual Estevill, Luis, El pago (Barcelona, Bosch, 1986), pp. 237-238 y de algún modo también Díez-Picazo, Luis, cit. (n. 2), p. 117, para quien la actuación de las partes en la relación obligatoria siempre se dirige a la satisfacción de un interés y por eso la obligación existe en función de ese interés, pero luego acota que en la obligación "...el deudor no puede quedar obligado a que el acreedor consiga la realización de tal fin, de aquél interés o de aquél resultado que persigue. El deudor cumple realizando la actividad a la cual está obligado. Su deber no es así un deber de satisfacción”. 
dor mediante el pago; en cambio, "solucionar", del latín solvere: "desligar, desatar" al deudor, mira más bien a la liberación del deudor por cualquier medio que se haga ${ }^{11}$.

El estudio del cumplimiento en forma autónoma, como efecto de las obligaciones y no como modo de extinguirlas permite, entre otras cosas, situar dogmáticamente en forma correcta los efectos que el cumplimiento o pago producen ${ }^{12}$. Cada vez que el deudor, con su conducta, desarrolla el programa de la prestación diseñado en el contrato, logra la satisfacción del interés del acreedor y con ello se produce, consecuencialmente, la extinción de la deuda y su liberación respecto del acreedor. Quedan así fijadas las tres funciones esenciales de todo pago: satisfactoria del interés del acreedor, extintiva de la obligación y liberatoria del deudor ${ }^{13}$.

Lo anterior ha llevado a un sector de la doctrina, tanto nacional como extranjera, a utilizar estas tres funciones como caracterizadoras del pago o cumplimiento, de modo que en todos aquellos casos en que no se dé alguna de ellas estaríamos, no frente a un pago estricto, sino frente a una figura diversa, que, sin embargo, por cumplir alguna de las otras funciones pasan a denomi-

\footnotetext{
${ }^{11}$ Cfr. Corominas, Joan - Pascual, José A., Diccionario critico etimológico castellano e hispánico (Madrid, Gredos, 2002), V, p. 337. Véanse también: Ulpiano, D. $42,1,4,7$; y Paulo, D. 46, 3, 54 y D. 50, 16, 47. Aunque en el derecho romano clásico la expresión venía utilizada sólo para las obligaciones de dar cosa cierta, cumplidas por el deudor o un tercero, en la época post clásica se generaliza y abarca también a las de hacer, que en principio sólo podían ser cumplidas por el deudor.

${ }^{12}$ Esta corrección sistemática al Código y doctrina tradicional se observa también en Alessandri R., Arturo - Somarriva U., Manuel - Vodanovic, Antonio, Tratado de las obligaciones (2a edición, Santiago, Editorial Jurídica de Chile, 2001), II, pp. 7 y 8. Lo observa para la unificación del derecho europeo de contratos, SALAS Murillo, Sofía, El cumplimiento del contrato en el anteproyecto de Código Europeo de Contratos, en Revista de Derecho Privado, 89 (Madrid, 2005) 5, pp. 33-34. También da cuenta de la dispersión normativa de la teoría del cumplimiento en el Derecho francés: LAITHIER, Yves-Marie, The Enforcement of Contractual Obligations: a French Pespective, en CARTwright, John - Vogenauer, Stefan - Whittaker, Simon (editores), Reforming the French Law of Obligations. Comparative Reflections on the Avant-projet de réforme du droit des obligations et de la prescription ('the Avant-projet Catala') (Portland, Hart Publishing, 2009), pp. 124-126, a pesar de lo cual, algunos textos de obligaciones modernos continúan con dicha dispersión, sobre lo cual véase: BÉNABENT, Alain, Droit Civil. Les obligations ( $11^{\text {a }}$ edición, Paris, Librairie générale de Droit et de Jurisprudence, 2007), pp. 517-518, que trata del pago por subrogación en el capítulo destinado a la circulación de los créditos.

${ }^{13}$ Cfr. Díez-Picazo, Luis, cit. (n. 2), pp. 541 y 542, quien en un sentido similar enumera tres funciones: ejecución de la prestación, liberación del deudor y satisfacción del deudor y las denomina "coordenadas" que deben confluir en la dinámica de la obligación para poder hablar de cumplimiento o pago.
} 
nar subrogado o sustituto del pago $^{14}$. Desde esta perspectiva, quedarían fuera del pago, entre otros, aquel efectuado por un tercero, ya que, como se verá, no se produce la liberación del deudor; y el pago por consignación, ya que, al menos en principio, no se produce la satisfacción del acreedor ${ }^{15}$.

En mi opinión, tales subrogados forman parte de la teoría general del cumplimiento y si bien puede que no siempre operen las tres coordenadas, ellos envuelven el efecto de producir la extinción de la relación obligatoria entre deudor y acreedor originales ${ }^{16}$. Es posible advertir, entonces, que una tesis subjetivista del pago, según la cual prevalece el deber de conducta del deudor hacia el acreedor, queda bastante superada ${ }^{17}$. Lo decisivo, es que se satisfaga al acreedor, siendo, por tanto, indiferente quien realice el cumplimiento ${ }^{18}$. Estimo, por ello, que el resto de las vicisitudes que puedan presentarse durante el cumplimiento puede ser considerado como modalidades del pago o cumplimiento ${ }^{19}$.

\section{LEGITIMACIÓN PARA EL PAGO}

El Código Civil trata el tema en el libro IV, título $14^{\circ}$, bajo el $\$ 2$ : "Por quien puede hacerse el pago", en términos amplísimos a primera vista: "Puede pagarpor el deudor cualquiera persona a nombre del deudor [...]”. Se comprende, entonces, al propio deudor (si bien no se lo menciona expresamente, del

${ }^{14}$ Abeliuk, René, cit. (n. 7), p. 578. También Beltrán de Heredia y CastaNo, José, El cumplimiento de las obligaciones (Madrid, Editorial Revista de Derecho Privado, 1956), pp. 8-11.

${ }^{15}$ Para el pago por consignación véase: Cano Hurtado, María Dolores, La consignación como mecanismo de liberación del deudor (Madrid, Dykinson, 2005).

${ }^{16}$ Cfr. Fueyo Laneri, Fernando, cit. (n. 9), pp. 58 y 63, para quien el contenido de la obligación se objetiviza en la fase del cumplimiento, que incluye el voluntario y el forzado. Con todo, estima que el pago de tercero es un subrogado del pago.

${ }^{17}$ Baraona González, Jorge, El retraso en el cumplimiento de las obligaciones (Madrid, Dykinson, 1998), pp. 90-93. Véase también: PALmero, Juan Carlos, El cumplimiento por el tercero (Buenos Aires, Ediciones Depalma, 1973), pp.45 y ss., quien postula una visión funcional del cumplimiento.

${ }^{18}$ Albiez Dohrmann, Klaus Jochen, Elpago por tercero, en Cuadernos de Derecho Judicial, 26 (1996), p 18.

${ }^{19} \mathrm{Cfr}$. Claro Solar, Luis, Explicaciones de Derecho civil chileno y comparado (ed. facsimilar, Santiago, Editorial Jurídica de Chile, 1979), XII, pp. 212 y 221. Véase el comentario de ARCE Flórez-VAldés, Joaquín, Extinción del contrato y de las relaciones que nacen del mismo, en VATTIER, Carlos y otros (director) Código Europeo de Contratos. Comentarios en homenaje al Prof. D. José Luis de los Mozos y de los Mozos (Madrid, Dykinson, 2003), II, p. 534, en que un concepto extensivo del cumplimiento, como el que se maneja en el Anteproyecto del Código europeo de contratos, integra los denominados subrogados del cumplimiento. 
sólo tenor literal se desprende que lo puede ya que si alguno puede hacerlo por él, con mayor razón puede hacerlo él mismo $)^{20}$ y al que no es deudor, que en adelante denominaremos tercero, sin perjuicio de volver, más adelante, sobre su calidad de no deudor.

\section{El deudor.}

A pesar de que nada diga el Código y tal vez por lo obvio que resulta, es claro que el primer legitimado para realizar el pago es el propio deudor, por cuanto viene obligado a ello. Refiriéndose a la ausencia de mención expresa del deudor, se ha dicho que "[E]llo sin duda obedece a que, por la esencialidad de este efecto jurídico [del pago], lo da como presupuesto o implicado en la cualidad de deudor" que "[...] en definitiva, se define por la obligación de llevar a cabo el cumplimiento" ${ }^{21}$. Su interés en el cumplimiento, por lo tanto, no necesita ser demostrado y su legitimación, por ende, no puede ser discutida ${ }^{22}$. Como advierte Díez-Picazo, otros son los problemas que plantea la regularidad del pago del deudor y ellos se refieren no a su legitimación, sino a la capacidad y poder de disposición sobre la cosa pagada cuando la obligación es de dar, materia que escapa al tema de este trabajo ${ }^{23}$.

En realidad, según Claro Solar, el deudor, más que poder pagar, debe pagar $^{24}$. Junto al deudor, en la misma situación, se encuentran sus herederos o legatarios a los que se ha impuesto el pago de una deuda, salvo que se trate de una obligación personalísima y por ello intransmisible (artículo 1097 CC.) y el representante legal, judicial o convencional del deudor, ya que, en virtud de la representación, se entiende que el pago lo ha hecho el propio deudor ${ }^{25}$.

En general, cuando cumple alguna de estas personas comprendidas bajo la designación del deudor, se dice que el pago extingue la deuda sin que se genere ninguna consecuencia posterior ${ }^{26}$. La situación, sin embargo, puede no ser tan simple y ello dependerá de cada caso concreto, ya que el mandatario

\footnotetext{
${ }^{20}$ Sin perjuicio de otras consideraciones dogmáticas que se verán a continuación.

${ }^{21}$ Hernández-GiL, Antonio, cit. (n. 3), p. 289, a propósito de los artículos 1158 y 1159 CCEsp., que también omiten la mención del deudor.

${ }^{22}$ Demolombe, Jean Charles Florent, Cours de Code Napoléon (Paris, Imprimerie Générale, 1872), XXVII, No 52.

${ }^{23}$ Díez-Picazo, Luis, cit. (n. 2), p. 549.

${ }^{24}$ Claro Solar, Luis, cit. (n. 19), p. 47. No obstante, según explica, los autores dicen que el deudor puede pagar para reforzar la idea que al deudor le asiste, junto con el deber, un verdadero derecho al pago, que puede ejecutar forzosamente mediante el pago por consignación. Véase Ramos Pazos, René, De las obligaciones ( $3^{\mathrm{a}} \mathrm{ed}$. revisada y corregida, Santiago, Legal Publishing Chile, 2008), pp. 342 y 344.

${ }^{25}$ Artículos 1448 y 671 CC.

${ }^{26}$ Ibíd., p. 345.
} 
podría tener derecho a cobrar una remuneración por el encargo, el heredero podría haber pagado una cantidad mayor a su cuota en la herencia, etc. En todos estos casos, el pago efectuado daría lugar a ciertas consecuencias de orden patrimonial destinadas, o bien, al reembolso del solvens, caso en que el mandatario hubiese anticipado fondos al mandante, o al reintegro del heredero por parte de sus coherederos. En todo caso, cada vez que actúa un tercero de este tipo lo efectos del pago se producen directamente en la persona del deudor, en consecuencia se actúan las tres funciones propias del pago: satisfactoria, liberatoria y extintiva de la deuda.

\section{Un tercero.}

La posibilidad de realizar el pago un tercero fue admitida desde los orígenes del Derecho romano a través de la figura de la solutio per aes et libram, en los períodos arcaico y preclásico ${ }^{27}$. El tercero debía ser una persona capaz, propietario de las cosas que afectaba y obrar animus solvendi. La intervención del tercero en deuda ajena tenía como claro fundamento mejorar la condición del deudor, sin tener en cuenta especialmente el interés del acreedor ${ }^{28}$.

Actualmente, el pago efectuado por un tercero se encuentra ampliamente reconocido en todas las legislacione ${ }^{29}$ y se le ha denominado, por la doctrina, "pago de o del tercero", aunque también recibe el nombre de pago de deuda

${ }^{27}$ Aunque esta forma solemne de pago se refería a las obligaciones cuyo objeto era un dare. Véase Bayo Recuero, Nieves, El pago del tercero (Madrid, Dijusa, 2000), pp. 28-36.

${ }^{28}$ D. 46, 3, 53 GAYo, "Cualquiera puede pagar por el que no lo sabe y aun se opone, ya que es un principio establecido de derecho civil que se puede mejorar la condición de una persona sin su conocimiento y contra su voluntad"; y D. 3, 5, 38 (39) GAYO, "Cuando paga uno por otro, aunque sea contra su voluntad o ignorándolo, le libera de la obligación; en cambio, lo que se debe a uno no lo puede reclamar otro sin consentimiento de aquél; pues la razón natural y la civil a un tiempo permiten que podamos mejorar la condición de otro, aun ignorándolo éste y en contra de su voluntad pero no podemos empeorarla”. El Digesto de Justiniano (trad. Álvaro d'Ors y otros, Pamplona, Aranzadi, 1968-1975).

${ }^{29}$ Se recoge esta legitimación, más o menos amplia, del tercero, en los ordenamientos español (artículo 1158 CC.), francés (artículo 1236 CC.), italiano (artículo 1180 CC.), alemán ( $\$ 267$ BGB.) y argentino (artículos 726 y ss. CC.), entre otros. En los sistemas del common law, no existe una legitimación especial del tercero para pagar, sin embargo, la materia es abordada desde la perspectiva del enriquecimiento injustificado y de la gestión de negocios ajenos. Véase para un análisis comparado: FriedmanN, Daniel - Cohen, Nili, Payment of Another's Debt, en Drobnig, U. - Zweigert, K. (editores) International Enciclopedia of Comparative Law (Tubinga, J.C.B. Mohr, 1991) X, pp. 55-76; y Macgregor, Laura J. - Whittr, Niall R., Payment of Another's Debt, Unjustified Enrichment and ad hoc Agency, en Edinburgh Law Review, 15 (2011) 1, pp. 57-87. 
ajena, lo que no es sólo asunto de términos sino que consustancial a la figura, no obstante que la disciplina comprende supuestos en los que el solvens es un verdadero deudor, como en los casos del codeudor solidario y del fiador, por lo que hacemos la salvedad, denominándolos "deudores no exclusivos" ${ }^{30}$. En efecto, para que se dé la situación de pago de tercero es esencial que la deuda sea ajena ${ }^{31}$, pero además, que el tercero pague conociendo esta circunstancia y con el ánimo de extinguir la deuda: animus solvendi. Por último, debe tratarse de una obligación cuya naturaleza admita ser cumplida por un tercero.

\section{Regulación en el "Código Civil".}

Ya hemos dicho que el Código trata del pago o cumplimiento como modo de extinguir las obligaciones, con un criterio marcadamente funcional que mira a los efectos de los actos y hechos jurídicos. De esta forma, los modos de extinguir las obligaciones se presentan teniendo como punto de unión su aptitud para provocar la extinción de la obligación ${ }^{32}$.

A pesar de ello, en la regulación del pago se vuelve a lo estructural y se atiende a distinguir los elementos del cumplimiento, sujetos y objeto, y dentro de los primeros, acreedor, deudor y terceros que pagan o reciben. En el caso que nos ocupa, del pago de tercero, se busca determinar si dicho acto cuenta o no con la voluntad del deudor y así se establecen ciertos efectos, como el derecho de reembolso de que dispondrá el solvens y el mayor o menor abanico de excepciones oponibles frente al mismo. No obstante lo anterior, es preciso resaltar que la regulación de los artículos 1572 a 1574 CC. no es suficiente para abarcar el panorama completo de efectos. Prueba de ello es la notoria dispersión sistemática que presenta en el Código el efecto subrogatorio del

${ }^{30}$ Terminología que utiliza Fernández Villa, José, El pago con subrogación: revisión del artículo 1.212 del Código Civil español (Granada, Comares, 1999), p. 369; también Hernández Moreno, Alfonso, El pago del tercero (Barcelona, Bosch, Casa Editorial, 1983), pp. 123-131, aunque con un matiz, ya que al codeudor solidario y al fiador les denomina "no deudores no exclusivos", siendo no deudores respecto de la parte de la deuda que no les interesa en el caso de los codeudores solidarios y respecto de la deuda del deudor principal en el caso del fiador o cofiadores.

${ }^{31}$ Respecto de estos deudores sólo se puede hablar de deuda ajena en sede de contribución a la deuda, cuando el codeudor que ha pagado es un no interesado en la obligación o ha pagado más allá de su interés en la deuda, es decir, la deuda pagada no es totalmente propia y sí es parcialmente ajena.

${ }^{32}$ GuZmán Brito, Alejandro, Identidad de funciones o efectos provenientes de la negocialidad entre vivos y por causa de muerte, en Revista de Derecho de la Pontificia Universidad Católica de Valparaíso, 32 (2009), p. 41, explica como el Código Civil, en su tarea sistematizadora, ha recurrido a un criterio más bien estructural, dejando de lado el punto de vista funcional, pero que ello no ocurre así tratándose de los modos de extinguir. 
pago que efectúan ciertos terceros (artículos 1573, 1608 a 1613, 1522, 2372 y 2429 CC., entre otros).

Hecha esta primera observación, podemos señalar que el pago realizado por un tercero, viene regulado, primeramente en el $\S 2$, tít. $14^{\circ}$ del libro IV CC., intitulado: "Por quién puede hacerse el pago". El artículo 1572 CC., primero del párrafo, habilita a cualquier persona a pagar por el deudor, sea que éste lo apruebe, lo rechace o lo ignore y aún contra la voluntad del acreedor ${ }^{33}$. Esta legitimación amplia concuerda plenamente con la definición de pago del artículo 1568 CC., que utiliza una redacción impersonal: que se preste lo debido, independientemente de quien lo haga, por lo que ampliamente se acepta el pago por otra persona distinta del deudor.

Como puede apreciarse, la legitimación de un tercero para intervenir en la obligación ajena en fase de cumplimiento es amplísima, al menos, tras una primera lectura $^{34}$, por cuanto la ley no toma en cuenta ni el interés del que paga, que puede existir o no ${ }^{35}$, ni la voluntad de los sujetos originarios de la relación obligatoria, para otorgar validez al pago. El tercero puede imponer el pago a ambas partes, sin perjuicio que los efectos variarán según sea la voluntad del deudor y del acreedor. En principio, la negativa del deudor restringirá las posibilidades de regreso por parte del solvens y la negativa injustificada del acreedor dará lugar a la mora accipiendi y eventual consignación - en caso de estimarse que el tercero está legitimado para ello.

Con todo, la amplitud de la norma admite restricciones, casos en los que sólo será posible al deudor cumplir en forma personal. Así, el mismo artículo 1572 , en su inciso $2^{\circ}$, considera el caso de las obligaciones de hacer en que se ha tomado en consideración la aptitud o talento del deudor, pues allí la ley reputa legítima la resistencia del acreedor para recibir el pago de una persona distinta que el deudor ${ }^{36}$.

Como dijimos, el pago de tercero tiene en el Código una primera regulación en los artículos 1572 a 1574 CC., mas, para comprender globalmente la situación del pago de tercero, no basta la consideración de los citados artículos, sino que es necesario incorporar otras normas del Código que también

${ }^{33}$ Un eventual rechazo del pago perfecto que ofrece un tercero puede ser combatido mediante la consignación, como se verá más adelante.

${ }^{34}$ En el último apartado se tratarán algunos límites a dicha intervención.

${ }^{35}$ Siempre existirá algún interés de parte del solvens, algo lo mueve a actuar; sin embargo no siempre ese interés revestirá una connotación jurídica capaz de intervenir los efectos normales del pago, lo que sí ocurre en el caso de los terceros que se subrogan por ley.

${ }^{36}$ Expresa el artículo 1572 inciso 20: "Pero si la obligación es de hacer, y si para la obra de que se trata se ha tomado en consideración la aptitud o talento del deudor, no podrá ejecutarse la obra por otra persona contra la voluntad del acreedor". 
vienen a regular la intervención del tercero, principalmente en cuanto a los efectos que produce su pago. Me refiero a los artículos 1610 a 1613 CC., que tratan del pago con subrogación ${ }^{37}$. También los artículos 2158 (mandato), 2290 y 2291 (agencia oficiosa), 1522 (codeudores solidarios), 2370 y siguientes (fianza) y 2429 (hipoteca), todos del CC., que tratan situaciones concretas de pago de tercero y sus efectos, en vía de regreso, para repetir en contra del deudor, sea por la subrogación en los derechos del acreedor o mediante el ejercicio de acciones personales de reembolso derivadas de la relación subyacente que pudiere existir entre solvens y deudor o para evitar un enriquecimiento injusto de parte de este último.

\section{Presupuestos del PAgo de UN TERCERo}

\section{Ajenidad de la deuda y concepto de tercero $0^{38}$.}

Este primer presupuesto está recogido en la propia ley, al disponer el artículo 1572 que "Puedepagar por el deudor cualquier persona a nombre del deudor [...]", lo que indica que lo que se va a pagar corresponde a la obligación del deudor, es decir, una obligación que, al menos en parte, resulta ajena ${ }^{39}$.

Nos encontramos frente al pago de un tercero toda vez que el cumplimiento de la obligación se lleva a cabo por quien no está obligado a satisfacer el crédito nacido de una relación obligatoria o no está obligado en forma exclusiva a ello ${ }^{40}$. Esta noción del pago de tercero es bastante amplia ${ }^{41}$ ya que comprende aquellas situaciones de ajenidad total de la deuda, que se predican respecto del tercero extraño a la relación obligatoria, el penitus extraneus y

${ }^{37} \mathrm{Al}$ igual que el Code, el Código chileno trata la subrogación por pago dentro de las normas del pago, no así el CC. español, que la trata dentro del título de la novación, lo que no ha estado exento de crítica por la doctrina científica.

${ }^{38}$ La existencia de la obligación misma constituye un requisito común a todo pago, razón por la que lo doy por supuesto. Además, de no existir la deuda, se entraría al campo del pago de lo no debido, sea que haya actuado el deudor o un tercero.

${ }^{39}$ Ya hemos hecho la precisión con que debe aplicarse el concepto "ajena" al codeudor solidario y al deudor subsidiario, pues justamente por ser deuda ajena es que se abre la fase de contribución a la deuda entre codeudores y de regreso para el fiador.

${ }^{40}$ Albiez Dohrmann, Klaus Jochen, cit. (n. 18), p. 20, se refiere a quien no está "obligado estrictamente a ello".

${ }^{41}$ En rigor y por exclusión, debiéramos decir que son terceros todos aquellos que no han concurrido con su voluntad a formar el contrato que crea la obligación, sin embargo y en palabras del profesor PiZarro WiLson, "hay terceros más terceros que otros" por lo que se acepta que el concepto se amplíe precisamente en la fase de ejecución del contrato -o del cumplimiento de las obligaciones- dejando atrás la sola atención al momento de la formación del mismo. Pizarro Wilson, Carlos, El efecto relativo de los contratos: partes y terceros, en GuZmán BRITO, Alejandro (editor), El Código Civil de Chile (1855-2005) (Santiago, LexisNexis, 2007), pp. 556-557. 
también aquellos casos en que el solvens, no obstante recibir la denominación de tercero ${ }^{42}$, posee en realidad la calidad de deudor frente al acreedor, lo que se entiende sólo por su carácter de deudor no exclusivo y en la medida que haya lugar a la fase de contribución a la deuda ${ }^{43}$.

Desde este punto de vista son terceros no sólo el absoluto, sino también el deudor subsidiario y el solidario. Estos últimos, en cuanto obligados, se encuentran en la posibilidad de verse afectados por la demanda del acreedor y de allí su interés en pagar, que justifica el efecto subrogatorio, pues al hacerlo cumplen su propia obligación. En efecto, el acreedor puede dirigirse contra cualquiera de los codeudores solidarios por el total de la deuda y el pago que realiza un codeudor solidario extingue la deuda respecto de todos (artículos 1514 y 1522 CC.). En el caso del fiador, típico deudor subsidiario, garantiza una deuda ajena pero es deudor de su propia obligación fideiusoria y cuando paga cumple su obligación a la vez que satisface el interés del acreedor, salvo que se haya obligado a menos ${ }^{44}$.

Por ello es que, profundizando un poco en la situación de estos sujetos, cabe preguntarse si son realmente terceros, es decir, personas ajenas a la relación obligatoria. La pregunta es válida ya que el pago propiamente tal, aquél que despliega y realiza todas sus funciones propias (satisfactoria, extintiva y liberatoria), es solamente el que efectúe un tercero sin subrogarse, pues sólo entonces el pago extinguirá completamente la obligación ${ }^{45}$. Considerando lo anterior, parte de la doctrina estima que existe pago de tercero, en sentido estricto, cuando se realiza el pago con el único fin de extinguir la obligación ${ }^{46}$.

${ }^{42}$ Por ejemplo, en el artículo 1612, el propio Código se refiere a aquellos obligados solidaria o subsidiariamente a la deuda como terceros.

${ }^{43}$ Vial del Río, Víctor, cit. (n. 8), p. 348, explica que en las relaciones jurídicas entre los codeudores se considera que la deuda es ajena para el deudor no interesado y lo mismo respecto del deudor interesado sobre aquella parte de la deuda que ha pagado por sobre la cuota que le corresponde.

${ }^{44}$ Véase: Reyes López, María José, Fianza y nuevas modalidades de garantía. Análisis critico de sus elementos y efectos. Comentarios y jurisprudencia (Valencia, Editorial General de Derecho, 1996), pp. 52 y 54.

${ }^{45}$ Por esta razón se ha visto en el derecho comparado, últimamente, una tendencia a abordar el pago de tercero desde el punto de vista de la subrogación; así, se trata del pago sin subrogación, como verdadero pago de tercero. Véase: CañIZAREs Laso, Ana, El pago con subrogación (Madrid, Civitas, 1996), quien, además, reconduce el pago de tercero a la gestión de negocios ajenos.

${ }^{46}$ En el derecho alemán, salvo el caso previsto en el $\$ 268$ del $B G B$., que subroga legalmente a ciertos terceros interesados, el pago de tercero es siempre un pago sin subrogación y la acción de regreso "condictio de regreso", tiene su fundamento en la doctrina del enriquecimiento injusto. Véase: Albiez Dohrmann, Klaus Jochen, cit. (n. 18), pp. 22 y 81. 
Ahora bien, siguiendo la línea que ha utilizado nuestro Código al referirse a los terceros, es posible distinguir tres categorías de terceros: $i$ ) aquellos que pagan y que son también verdaderos deudores; $i$ ) aquellos que pagan y tienen interés en el pago; y iii) aquellos que pagan y que son completos extraños a la obligación.

En el primer grupo, como ya se dijo, están el codeudor solidario y el deudor subsidiario, que, no obstante ser verdaderos deudores frente al acreedor, son denominados terceros ${ }^{47}$ porque la deuda que pagan es en parte ajena, lo que se observa en toda la etapa de contribución a la deuda y en la vía de regreso del fiador. Este aspecto de la solidaridad pasiva y de la fianza coincide con su carácter de cauciones.

En el segundo grupo o categoría se encuentran aquellos que, sin ser deudores, pueden igualmente verse expuestos a la demanda del acreedor y por eso tienen interés en el pago de la obligación. De alguna manera no son extraños a la obligación ya que de ese pago depende la consolidación de su derecho.

En la tercera categoría encontramos al tercero absoluto, aquél que institucionalmente quede fuera de la relación obligatoria, aunque puede intervenir en ella con posterioridad ${ }^{48}$. A estos efectos, la subrogación legal es útil para completar la configuración de este tercero, en orden a que es tan ajeno a la deuda que no puede compeler al acreedor a subrogarlo, de modo que el pago que realiza cumple siempre todas las funciones que le son propias, satisface, extingue y libera al deudor.

A objeto de poder delimitar más aún el concepto, algún autor ha hablado del "no deudor" como categoría de persona más amplia que la de tercero o extraño a la obligación ${ }^{49}$. Es efectivamente más amplia ya que todo tercero y todo extraño no deben, no están obligados a cumplir la deuda ajena, pero no todo no deudor es un tercero o un extraño; $v$, gr. el poseedor de la finca hipotecada, no debe la obligación y sin embargo no es un extraño. Este tercero, no deudor, no es extraño precisamente porque tiene un interés, cual es no perder sus derechos sobre la cosa hipotecada en favor de otro y "[E]

${ }^{47} \mathrm{El}$ artículo 1612 habla de terceros, precisamente, para indicar a aquellos que pueden venir obligados subsidiaria o solidariamente a la deuda.

${ }^{48}$ Este tercero es el que definió Renusson, en el que se conoce como el primer tratado sobre subrogación (Traité de la subrogation. De deux qui succedent au lieu \& place des créanciers), el tercero completamente extraño a la obligación, que no es codeudor, ni fiador, ni propietario del bien hipotecado o pignorado en garantía del cumplimiento de la obligación, ni acreedor posterior, ni coheredero. Véase: FERNÁNDEZ Villa, José, cit. (n. 30), p. 383; y Hernández Moreno, Alfonso, cit. (n. 30), p. 121.

${ }^{49}$ Ibíd., pp. 124 y 125. 
se interés le cuesta un pago, si bien puede trascender a este" ${ }^{\text {"50 }}$. Con ello se quiere decir que, desde el momento en que aparece el interés, desaparece la noción de extraño. Lo interesante de estas observaciones, me parece, es que nos permiten, desde ya, una importante aseveración: al tercero extraño la ley sólo le otorga una legitimación simple, en el sentido que su pago sólo puede producir los efectos normales de todo pago y no uno distinto, como sería el efecto subrogatorio que impide la función liberatoria del deudor. A la inversa, aquellos terceros no extraños poseen una legitimación cualificada para el pago, en un doble sentido, como se verá: pueden pagar resultando efectos especiales de este pago, el subrogatorio, y además, pueden imponer el pago resistiendo la voluntad conjunta del acreedor y del deudor, mediante la consignación, cosa que no puede hacer el tercero absoluto, que no posee un interés propio cualificado. Confirma lo anterior el hecho que el No 5 del artículo 1610 CC., no obstante referirse a un tercero absoluto, le concede la subrogación legal pero, exigiendo para ello, que el deudor lo legitime en forma especial prestando su consentimiento para el pago.

En el caso del tercero absoluto o extraño su interés se confunde con el propio del deudor ya que el pago producirá siempre la extinción de la deuda y la liberación del deudor, el solvens actúa en interés del deudor; en cambio, el tercero interesado introduce el suyo propio y por eso su pago no producirá los efectos normales del pago, no liberará al deudor pues adquirirá el mismo crédito en beneficio de una mayor seguridad propia.

Tal es así, que en el caso de la simple legitimación, aquella que corresponde a todos sin necesidad de plantear un interés especial para pagar, los supuestos del artículo 1572 CC. se concretan en relaciones subyacentes entre deudor y tercero que constituyen gestión del interés ajeno, del deudor. Así prevén los artículos 2119, 2120, 2129 y 2149 CC., en relación al mandato y los artículos 2287 y 2288 CC., para la agencia oficiosa.

\section{2. "Animus solvendi".}

Con respecto al elemento intencional que más arriba adelantamos, es necesario, como en todo pago, que concurra en el tercero la voluntad de querer extinguir la deuda ajena mediante el pago que realiza, es decir, "la voluntad de llevar a cabo un acto de cumplimiento" 51 . Se ha dicho que el animus solvendi es el punto de contacto con la obligación ajena: "el tercero, a diferencia de lo que ocurre con el deudor, no está vinculado en la relación obligatoria, y, por tanto, si prescinde de su animus solvendi, se pierde también todo punto de referencia y aun de justificación respecto de su incidencia en

\footnotetext{
${ }^{50}$ Ibíd.

${ }^{51}$ Díez-Picazo, Luis, cit. (n. 2), p. 587.
} 
el débito ajeno" 52 . En caso contrario, podría darse un supuesto de pago de lo no debido, si el tercero paga en la creencia errónea de estar cumpliendo su propia obligación, en cuyo caso podrá repetir lo pagado contra el acreedor, ex artículo 2295 CC. 53 .

El Código recoge estas ideas al disponer que el pago se realice "por el deudor" o "a nombre del deudor". El pago realizado por un tercero por el deudor o a su nombre, excluyendo los casos de representación por corresponder a un pago del deudor, importa la consciencia del solvens de estar pagando deuda ajena, es decir, perfecto conocimiento de que él no es deudor en dicha relación obligatoria. Si el tercero pagase la deuda ajena creyendo, por error, ser deudor de la misma, podrá ejercitar la acción de pago de lo indebido y al efecto dispone de la presunción del artículo 2299 CC. ${ }^{54}$. En este caso, si el tercero sabe que pagó por error, no podrá dirigirse contra el deudor aduciendo el pago por tercero, ambas figuras se excluyen mutuamente.

Parte de la doctrina se pregunta si es necesario que el animus solvendi conste de alguna manera en el pago o si es posible presumirlo. Ello, porque si el pago no es indebido y tampoco consta el animus donandi del tercero, parece lo más lógico pensar que se trata de un pago de tercero solvendi cau$s a^{55}$. Concuerdo con este planteamiento ya que, en caso contrario, al tener que probarse el animus solvendi, podría ocurrir que ante la falta de prueba el tercero quedara en una posición en extremo gravosa, ya que sólo le quedaría el camino de intentar una acción por pago de lo no debido frente al acreedor, si bien con la presunción del artículo 2299 CC. a su favor. En cambio, de presumirse el animus solvendi habrá lugar a las acciones de reembolso y corresponderá al deudor la carga de la prueba cuando quiera excepcionarse

${ }^{52}$ Cristóbal Montes, Angel, El pago o cumplimiento de las obligaciones (Madrid, Tecnos, 1986), p. 51. Este requisito del animus, discutido por quienes ven al pago como un hecho, es lo que califica su naturaleza jurídica como acto jurídico y se aprecia aquí, en el pago de tercero, como más evidente que debe existir, excluyendo una concepción puramente mecanicista de coincidencia externa entre el pago y el acto debido.

${ }^{53}$ También puede subrogarse en las acciones del acreedor contra el deudor cuando se ha cancelado el título necesario para el cobro. Se ha fallado que cuando una persona a consecuencia de un error suyo, ha pagado una deuda ajena, puede intentar contra el deudor las acciones del acreedor, probando que nada debía respecto de dicho crédito y que éste fue pagado con dineros de su patrimonio personal, por un error. Corte $\mathrm{Su}$ prema (en adelante CS), 23 de noviembre de 2004, en Fallos del Mes, 528 (2004), pp. 2782 ss.

${ }^{54} \mathrm{El}$ sistema chileno recoge un concepto restringido de la condictio indebiti, ya que exige, para haber derecho a repetir el pago, que la atribución patrimonial se haya debido a error; el sistema germánico, en cambio, la concibe en sentido amplio y hace lugar a la repetición de todo pago que importe una atribución patrimonial que no tenga por fundamento una causa justa. Véase: Díez-Picazo, Luis, cit. (n. 2), p. 588.

${ }^{55}$ Albiez Dohrmann, Klaus Jochen, cit. (n. 18), p. 25. 
en vía de regreso, demostrando que el tercero, actuando a nombre propio, realizó un pago indebido o lo hizo animus donandi, intención que el derecho no presume. Luego, "probado por el tercero que ha cumplido la obligación a satisfacción del acreedor, debería ser suficiente para hacer valer las acciones que le corresponden frente al deudor" 56 .

\section{Que la obligación admita el cumplimiento por tercero.}

Dijimos, más arriba, que la amplitud de la legitimación para el pago reconocía una limitación en el mismo artículo 1572 CC., referida a la naturaleza de la obligación que se trata de cumplir. Así, en las obligaciones de hacer que se hayan pactado en atención a la aptitud o talento del deudor, no podrá ejecutarse la prestación por otra persona contra la voluntad del acreedor, sólo será posible al deudor cumplir en forma personal.

Se trata de las denominadas obligaciones personalísimas, que no admiten la posibilidad de reemplazar al deudor en el cumplimiento, ni siquiera por un representante, de modo que si fallece el deudor la obligación no se transmite a sus herederos sino que queda extinguida.

Obviamente, nada obsta a que con acuerdo del acreedor pueda otra persona, distinta del deudor, cumplir este tipo de obligación. En este caso, sin embargo, es fundamental el consentimiento del acreedor, ya que, al igual que ocurre con la dación en pago, se está alterando el principio de identidad del pago: en su virtud, la obligación debe cumplirse al tenor de lo pactado y el acreedor no podrá ser obligado a recibir otra cosa que lo que se le deba (artículo 1569 CC.). En la obligación que considera las circunstancias personales del deudor, de aptitud o talento, éstas quedan incorporadas en el objeto mismo de la obligación, en la prestación misma debida y por ello el pago por un tercero viene a ser un aliud pro alio.

La doctrina ha discutido si esta norma de excepción es sólo aplicable a las obligaciones de hacer, cosa que aparentemente el Código no resuelve. Pareciera que en las obligaciones de dar, en principio, no importara el sujeto que paga, sin embargo la ley ha dispuesto ciertas exigencias para el solvens (artículo 1575 CC.), que si bien no constituyen una exclusión de carácter general, sí pueden afectar al tercero que intenta pagar, de modo que habilitarían al acreedor a rechazar el pago ${ }^{57}$.

\section{Los requisitos de todo pago.}

Aunque resulte obvio, no está de más consignar que el pago ofrecido por el tercero debe reunir los mismos requisitos que si lo hiciese el deudor: iden-

\footnotetext{
${ }^{56}$ Ibíd.

${ }^{57}$ Sobre esto se volverá en la parte final del trabajo.
} 
tidad, integridad, indivisibilidad y demás circunstancias de tiempo y lugar; la falta de alguno de ellos faculta al acreedor para negarse a aceptar el pago que el tercero le ofrece en los mismos términos que si el pago lo ofreciese el deudor. Asimismo, el pago debe ser hecho al acreedor, a su representante o al diputado para recibir el pago.

Los artículos 1568, 1569 y 1591 CC., que destacan estos aspectos, son con igual o mayor razón aplicables al pago que intenta un tercero, todo lo cual es sin perjuicio del acuerdo del acreedor en orden a aceptar un pago de prestación distinta de la debida, un pago parcial o en tiempo y lugar diversos a los convenidos originariamente ${ }^{58}$.

Si bien nada impide que sea así, no puede ello significar mayor gravamen para el deudor en la vía de regreso. Evidentemente que si el deudor ha autorizado el pago en términos distintos a los originariamente convenidos con su acreedor, podrá el tercero exigir al deudor la misma prestación que ha realizado para satisfacer al acreedor, pero cuando ha actuado en la ignorancia del deudor o contra su voluntad sólo podrá exigir el reembolso atendiendo a la prestación original.

Si el tercero sólo ha pagado una parte de la deuda, dependerá de la actitud asumida por el acreedor: si acepta o no el pago parcial. No está, desde luego, obligado a aceptar, pero podría hacerlo dándose por satisfecho, con lo que se entenderá extinguida la deuda y el solvens podrá dirigirse contra el deudor por lo que haya pagado. Si sólo acepta el pago parcial manteniendo la deuda por el saldo, el acreedor podrá exigir al deudor el cumplimiento íntegro de la prestación y éste estará obligado a él, por lo que el solvens sólo tendrá acción para recuperar la parte que haya pagado y en caso de subrogación, lo prefiere el acreedor originario.

Si existía un plazo pendiente, dependerá a favor de quien operaba dicho plazo. Si se encontraba establecido en favor del acreedor, nada impide que renuncie al plazo aceptando el pago anticipado que le ofrece un tercero. Si el beneficio del plazo estaba concedido al deudor, el pago anticipado sólo permitirá al tercero dirigirse contra el deudor al término del mismo, salvo que el deudor hubiere consentido el pago anticipado, lo que implica su renuncia al plazo.

Si el plazo estaba convenido a favor de acreedor y deudor, podrá el ter-

${ }^{58}$ Una completa exposición de los casos en que el tercero extingue la deuda ajena sin mediar un pago perfecto ha sido elaborada por Nicolò, Rosario, L'adempimento dell obbligo altrui (Milano, Giuffrè, 1936), quien denomina a estos casos como "cumplimiento indirecto de deuda ajena"; entre otros, se refiere a la expromisión, dación en pago y compensación. 
cero anticipar el pago con acuerdo del acreedor, respetando el vencimiento original al dirigirse contra el deudor ${ }^{59}$.

\section{La utilidad del pago, ¿es realmente un presupuesto?}

En este punto no pretendo referirme a la utilidad del pago desde un punto de vista objetivo, como que el pago extinga la obligación, ya que estimo queda subsumido en el presupuesto anterior.

Lo que aquí se pretende analizar es si el pago debe ser útil al deudor como presupuesto necesario para hallarnos ante el pago de un tercero. El criterio es netamente subjetivo, desde el punto de vista del deudor y mira a los efectos del pago en la relación solvens-deudor.

Gran parte de la doctrina exige, como requisito del pago de tercero, que éste haya sido útil al deudor, de este modo señalan que se “[...] matiza, en parte la amplia legitimación que concede el ordenamiento jurídico para cumplir la obligación ajena"60. Pienso, sin embargo, que la utilidad del pago no constituye propiamente un requisito de la figura, toda vez que el pago perfecto realizado por un tercero tendrá siempre la virtualidad de extinguir la deuda satisfaciendo al acreedor, independientemente de los efectos que produzca en la relación de regreso con el deudor. Las distintas vías de reembolso que ostenta el solvens frente al deudor permiten a éste, en mayor o menor medida, juzgar esta utilidad y oponer por vía de excepción su alegación destinada a probar la inutilidad del pago. En el caso más extremo, cuando el tercero ha actuado contra la expresa voluntad del deudor, será aquél quien deba probar la utilidad del pago y sólo podrá resarcirse en la medida que dicha utilidad exista al tiempo de la demanda; si no la hay, nada podrá reclamar del deudor. En los otros supuestos, me parece que debe traerse a colación el comportamiento diligente exigido al tercero, sea mandatario o agente oficioso, por lo que no basta con pagar sino que además deberá informarse de las particularidades de la deuda ajena. "La utilidad del pago presupone una determinada actitud hacia el deudor" 61 , que la ley presume en los casos que otorga la acción de reembolso, no así cuando se actúa contra la voluntad del deudor. Estimo, por tanto, que así es como la ley concreta el amparo de sus intereses frente a un pago inútil, que con todo, ha extinguido la deuda.

\footnotetext{
${ }^{59}$ Cañizares Laso, Ana, cit. (n. 45), pp. 108-110.

${ }^{60}$ Albiez Dohrmann, Klaus Jochen, cit. (n. 18), p. 28.

${ }^{61}$ Ibíd.
} 


\section{FUNDAMENTO DE LA LEGITIMACIÓN DE UN}

TERCERO PARA EL PAGO

El tercero que pretende cumplir una obligación ajena, salvando la situación de los codeudores solidarios y de los responsables subsidiarios, en los hechos, se está inmiscuyendo en una relación jurídica respecto de la cual es un extraño, pues no concurrió con su voluntad a formarla, ha nacido al margen suyo ${ }^{62}$. Es por ello necesario determinar qué razón ha tenido el derecho para permitir esta injerencia. Tradicionalmente, se sostenía la legitimación del tercero en que el pago mejoraba la situación del deudor y de acuerdo al principio de que cualquiera puede mejorar la situación de otro no se veía razón alguna para limitar la intervención del tercero ${ }^{63}$. Este principio, vigente ya en el Derecho romano clásico, pasa del mismo modo a las Partidas y al Código ${ }^{64}$.

Hoy en día, la dinámica de las relaciones jurídico-económicas justifica o propicia también la injerencia de terceros en la fase de cumplimiento de las obligaciones, sobre todo teniendo en cuenta que se ha redirigido la atención hacia el acreedor, pues se entiende que hacia la satisfacción de su interés está ordenada la obligación y el contrato en general ${ }^{65}$. La admisión del pago de tercero es una más de las demostraciones de esta tendencia en cuanto al concepto de obligación vigente en nuestros días, ya que, sin duda,

${ }^{62}$ Diferente es la situación de aquellos interesados en el pago que son verdaderos deudores frente al acreedor y sólo terceros en cuanto la deuda les es, en parte, ajena: los codeudores solidarios y los responsables subsidiarios. Ya veremos como su legitimación arranca del interés que poseen en el pago, interés, por lo demás, calificado.

${ }^{63}$ Esta idea viene directamente de GAYO, D. 46, 3, 53 y D. 3, 5, 38 y la recoge el Code en su artículo 1236. Claro Solar, Luis, cit. (n. 19), p. 51, comenta la idea de Larombiére sobre dicho artículo 1236, para quien corresponde a un mandato de humanidad y de fraternidad de querer mejorar la posición de otra persona. Sin embargo, como se verá, no es el ánimo de liberalidad lo que siempre inspira la actuación del tercero que paga, sino la satisfacción de su propio interés en la extinción de la deuda o bien, el desempeño de un mandato o gestión oficiosa.

${ }^{64} \mathrm{Se}$ disponía en la ley $3^{\mathrm{a}}$, tít. $14^{\circ}$ de la Partida V: "non tan solamente es quito ome de lo que deue, faziendo paga dello por si mismo mas faziéndolo aun otro cualquier por el en su nome. E maguer aquel que deue aquel debdo no supiesse que otro fazia la paga por él, con todo esso sería quito. E aunque lo supiesse e lo contradixesse".

${ }^{65}$ También se señala como criterio del legislador para la amplitud de la legitimación del tercero un interés social en que las deudas se paguen y exista el menor número de personas obligadas, lo que, me parece, a veces no es tan exacto que se cumpla mediante el pago de tercero ya que de todos modos se producen efectos obligacionales entre el solvens y el deudor, a veces mediante la pervivencia del mismo crédito y otras mediante el nacimiento de uno nuevo a partir del pago. Cfr. Ramos Pazos, René, cit. (n. 24), p. 347. 
facilita la realización del crédito en beneficio del acreedor. La amplitud de la legitimación se encuentra plenamente justificada toda vez que, por regla general, lo que al acreedor le interesa es la prestación, siéndole indiferente la persona que le pague -fungibilidad del deudor-, siempre y cuando se cumplan los requisitos objetivos del pago, de identidad e integridad, y las demás circunstancias de tiempo y lugar.

El interés protegido del acreedor reviste un carácter social típico en el derecho, para cuyo logro la prestación es objetivamente idónea. Pero esto no es suficiente para conocer el interés del acreedor, será necesario ir más allá de la idea de Betti, en que el interés en la prestación es el propio y específico del tipo de relación constituida y no aquél concreto e individual del acreedor en particular, por lo que autores como Di Majo, alertan que a veces será necesario conocer el interés individual concreto del acreedor; precisamente, para sostener que un interés "apreciable" del acreedor puede constituir un límite a la general admisibilidad del pago del tercero ${ }^{66}$. Luego, en un sentido funcional, el pago es satisfacción del interés del acreedor y por ello caben en el concepto tanto el que realice el mismo deudor como un tercero. En nuestro Código, aún contra la voluntad del deudor y a pesar del acreedor, cosa que otros ordenamientos -como el italiano- han atenuado, permitiendo al acreedor rehusar el pago del tercero cuando el deudor le ha manifestado su oposición ${ }^{67}$. Luego, por regla general, salvo que se trate de obligaciones personalísimas, cualquier persona puede satisfacer el crédito mediante la realización íntegra y exacta de la prestación, sin que se requiera el consentimiento del acreedor.

Su negativa injustificada resultaría abusiva y contraria a la buena fe "[...] pues perjudica otros intereses legítimos, ya sean del tercero o del propio deudor" ${ }^{\prime 6}$. El pago del tercero que viene obligado directa o accesoriamente a la obligación, piénsese en contratos complejos, conexos o subcontratos ${ }^{69}$,

${ }^{66} \mathrm{Cfr}$. Betti, Emilio, Teoría general de las obligaciones (trad. J. L. de los Mozos, Madrid, Editorial Revista de Derecho Privado, 1969), I, p. 66; y Di Majo, Adolfo, Adempimento in generale, en GaLGANo, Francesco (director), Commentario del Codice Civile, Scialoja-Branca (artículo 1177-1200) (Bolonia-Roma, Zanichelli, 1994), p. 64.

${ }^{67} \mathrm{El}$ artículo 1180 del CC. italiano dispone: "Adempimento del terzo. L'obbligazione può essere adempiuta da un terzo, anche contro la volontà del creditore, se questi non ha interesse a che il debitore esegua personalmente la prestazione. Tuttavia il creditore puó rifutare l adempimento offertogli dal terzo, se il debitore gli ha manifestato la sua opposizione."

${ }^{68}$ Gómez-Blanes, Pablo, La condictio de regreso por pago de tercero, en Revista Critica de Derecho inmobiliario, 716 (noviembre-diciembre de 2009), p. 2821.

${ }^{69}$ En estos tipos contractuales la calidad de tercero asume un significado relativo pues cada una de las partes no es un tercero respecto de otro contrato del mismo grupo contractual, con lo que se plantea en la doctrina la necesidad de revisión o relectura del 
que imponen la calidad de codeudor o deudor subsidiario, se explica, por este mismo motivo, en su interés: el tercero se halla expuesto a la demanda del acreedor ${ }^{70}$. Por esta razón tiene derecho a pagar obligando al acreedor a recibir el pago en un momento favorable para dirigirse en vía de regreso contra el deudor ${ }^{71}$.

El interés del acreedor ha sido considerado por el legislador no sólo para admitir la injerencia de un tercero en la obligación, extinguiéndola, sino también a la hora de regular los efectos que este pago puede producir entre los demás sujetos involucrados. Así, cuando opera la subrogación legal en el crédito, se produce una verdadera alteración de lo pactado por las partes de la relación obligatoria, de modo que, stricto sensu, la ley debiera repudiar dicha situación si no se cuenta con la voluntad conforme de deudor y acreedor. En cambio, no lo hace y ello obedece a la ponderación de intereses en juego: por una parte al deudor podría interesarle mantener su vínculo con el acreedor originario en vez de quedar a merced de un acreedor tal vez más exigente -el subrogado- pero se ha optado por privilegiar el interés del acreedor a la satisfacción de su crédito (lo mismo que ocurre en la cesión de derechos); puede ocurrir que al acreedor le repugne la idea de verse sustituido por otro más exigente, pero si el propio deudor ha consentido el pago y este es perfecto, entonces la ley nada puede hacer por el acreedor que pretende favorecer a su deudor en circunstancias que él mismo ha prestado su voluntad; por último, también el interés del tercero se sobrepone al de las partes y la ley le concede, a este interés jurídicamente cualificado la protección consistente en la subrogación legal, independiente de la voluntad de acreedor y deudor ${ }^{72}$. Así, por lo demás, quedó plasmada en el Code la opinión de Dumoulin, que abogó por que la ley supliera el olvido del fiador o del codeudor solidario, otorgándoles el beneficio de la subrogación, de pleno derecho y sin necesidad de ninguna requisición por su parte ${ }^{73}$.

efecto relativo del contrato. Cfr. Larroumet, Christian, Teoría general del contrato (trad. Jorge Guerrero R., Bogotá, Temis, 1999), II, p. 210. Véase también LópEz SANTA MARÍA, Jorge, Las cadenas de contratos o contratos coligados, en Revista de Derecho de la Pontificia Universidad Católica de Valparaiso, 19 (1998), pp. 159-166; y Pizarro Wilson, Carlos, cit. (n. 41), pp. 560-567.

${ }^{70}$ Albiez Dohrmann, Klaus Jochen, cit. (n. 18), p.17.

${ }^{71}$ Claro Solar, Luis, cit. (n. 19), p. 48, “[...] en lugar de esperar que este recurso llegue a ser ilusorio por la insolvencia del deudor.”

${ }^{72}$ Díez-Picazo, Luis, cit. (n. 2), p. 617.

${ }^{73}$ Del Olmo García, Pedro, Pago de tercero y subrogación (Madrid, Civitas, 1998), p. 175, en que refiere las diferencias que sobre la materia existían entre Pothier y Dumoulin, específicamente sobre el carácter legal de la subrogación. 


\section{Supuestos del pago de un tercero, 1: Generalidades}

Como ya hemos dicho, el Código Civil prevé, en su artículo 1572, que puede pagar por el deudor cualquier persona, sin distingo de la voluntad del acreedor o del deudor en cuanto a la admisión del pago, sino sólo en cuanto a reconocer al pagador unos derechos más o menos amplios en contra del deudor por el que ha pagado.

En lo que respecta a la actitud del acreedor, éste carece de posibilidades técnicas para impedir el pago y satisfacción de su derecho por parte de un tercero ajeno a la obligación.

La actitud del deudor, por su parte, es más relevante, por cuanto ciertos efectos de ese pago dependerán, en gran medida, de su aquiescencia, ignorancia u oposición al mismo.

En lo que dice relación con la actitud del tercero, entendida como su motivación para el pago, nada se dice, de modo que, siendo irrelevante, no es parte ni requisito de tal legitimación.

El interés del tercero, sin embargo, viene reconocido y exigido para la legitimación especial de que trata el artículo $1610 \mathrm{CC}$. En efecto, si como hemos dicho, el efecto normal del cumplimiento o pago es la extinción de la obligación y de todos sus accesorios, en el caso de pago por tercero este efecto operará con ciertas modalidades: en ocasiones se extinguirá completamente la deuda y sus accesorios (fianzas, privilegios, prendas e hipotecas que le servían de garantía), cumpliéndose las tres finalidades propias del pago que hemos reseñado, satisfactoria del interés del acreedor, extintiva de la obligación y liberatoria del deudor; otras veces, cuando haya subrogación, sólo se producirá la extinción "parcial" de la obligación, ella quedará extinguida respecto del acreedor pero no del deudor, por lo que sólo se cumplirá la función satisfactoria, quedando la obligación subsistente entre el tercero que pagó y el deudor, es decir, no se desarrollará la función extintiva en plenitud ni la liberatoria del deudor ${ }^{74}$.

Para realmente comprender lo que hay detrás de la intervención de un tercero en el pago, es necesario investigar por qué una persona ajena a la obligación lleva a efecto su cumplimiento, lo que nos llevará también a determinar qué relación une al deudor con el tercero, si es que alguna y de ese modo, completar el plexo de posibilidades de regreso con que cuenta el tercero que pagó ${ }^{75}$. Lo anterior no reviste mayor novedad en la forma de

${ }^{74}$ Sobre la naturaleza jurídica de la subrogación y cómo es posible que una deuda se extinga y no se extinga al mismo tiempo Véase Rubio Garrido, Tomás, La subrogación por pago. Régimen jurídico y supuestos prácticos de aplicación (Madrid, McGrawHill, 1997), pp. 39-79.

${ }^{75}$ Como observa Gómez-Blanes, Pablo, cit. (n. 68), p. 2831, el pago de un tercero 
abordar el pago de tercero, ya el Derecho romano al conceder la vía de regreso al solvens asociaba cada una de las hipótesis de pago de tercero a distintos supuestos de relación obligacional entre solvens y deudor ${ }^{76}$. Como advierte un autor "todas las teorías sobre los efectos del pago de tercero terminan, inevitablemente, por reconocer la necesaria subordinación de cualquier tipo de construcción a la realidad multiforme de las relaciones subyacentes", lo que se hace más evidente en el caso del tercero no interesado ${ }^{77}$. Así, podría ocurrir que: $i$ ) el tercero no fuese realmente ajeno a la obligación de modo que pudiera verse expuesto a la demanda del acreedor, es decir, lo liga una relación de responsabilidad por la obligación; ii) el tercero fuese, a su vez, deudor del deudor y hubiere recibido una delegación para el pago -con lo que saldaría su propia deuda-; iii) el tercero fuese mandatario del deudor (sin representación, pues habiéndola quedaría contemplado en el caso del pago por el propio deudor); o iv) el tercero actuase como gestor oficioso de los negocios del deudor; sólo por mencionar algunos de los vínculos subyacentes, pero todos ellos encuentran su correlato estructural en los términos de los artículos 1572 a 1574 CC. ${ }^{78}$.

La doctrina, en general, es uniforme al reconocer esta amplia legitimación del tercero para el pago, pero no así respecto de los efectos que ese pago produce, principalmente a la hora de fijar los alcances del derecho de regreso que ostenta el solvens. En todo caso, las distintas vías que el ordenamiento contempla responden al principio que repudia el enriquecimiento injustificado, toda vez que persiguen un fin recuperatorio respecto del pago efectuado solvendi causa. Para aquellos autores que no reconducen la figura del pago de tercero a los supuestos de mandato o gestión de negocios, la acción de reembolso comprende solamente lo pagado por el tercero ${ }^{79}$. Sin embargo, si como hace la mayoría de la doctrina ${ }^{80}$, se vincula el ejercicio de esta acción al régimen específico que regula la relación subyacente, entre solvens y deudor, (v. gr. el mandato, la agencia oficiosa), ella tendrá también carácter indemnizatoria.

Para conocer los efectos que el pago de tercero produce se abordarán los

se encuadra dentro de un concepto más amplio de gestión de negocios ajenos, comprendiendo no sólo al gestor oficioso sino también al que actúa por encargo y tanto al que actúa sobre la base de un interés propio como ajeno del deudor.

${ }^{76}$ Véase el detallado estudio de BAyo Recuero, Nieves, cit. (n. 27), pp. 21-102.

${ }^{77}$ Gómez-Blanes, Pablo, cit. (n. 68), p. 2833.

${ }^{78}$ Una relación de los posibles intereses que mueven al tercero a pagar en DíEZPicazo, Luis, cit. (n. 2), pp. 553 y 554.

${ }^{79}$ Albiez Dohrmann, Klaus Jochen, cit. (n. 18), p. 81.

${ }^{80}$ Por todos, Abeliuk Manasevich, René, cit. (n. 7), pp. 548-551. 
supuestos de hecho de cada figura de pago de tercero e inmediatamente, las consecuencias jurídicas precisas que se derivan de cada una.

Estiman los autores que el tercero puede adquirir cuatro acciones básicas: i) la acción derivada de la subrogación en los derechos del acreedor, en los casos en que paga un tercero interesado en el cumplimiento de la obligación o con el conocimiento y aprobación del deudor (artículos 1574 a contrario y 1610 CC.); ii) la acción de reembolso surgida ex novo, para los pagos efectuados con conocimiento y aprobación del deudor; iii) la acción de reembolso cuando paga sin el conocimiento del deudor (artículo 1573 CC.); y $i v$ ) la de enriquecimiento, surgida también ex novo, cuando paga contra la voluntad del deudor (artículo 2291 CC. $)^{81}$.

Para configurar cada uno de los supuestos que originan estas diversas acciones, la ley ha atendido a la voluntad o actitud del deudor (conocimiento y aprobación, ignorancia o rechazo del pago) y a la calidad del interés que induce al tercero a pagar. En cambio, dan fisonomía a cada una de estas vías de regreso diversas consideraciones, como son: $i$ ) la persistencia o extinción del crédito y sus accesorios; ii) la cuantía de lo que el solvens está habilitado para reclamar (el importe de lo pagado, el valor nominal del crédito, intereses, gastos, etc.; y iii) la admisibilidad de excepciones y defensas por parte del deudor reclamado que enerven la acción o disminuyan su cuantía ${ }^{82}$.

Todas estas variables han de considerarse para articular adecuadamente el régimen del pago de tercero en nuestro Derecho, materia que, como ya se ha observado, en el Código Civil no aparece tratada de modo sistemático; muy por el contrario, las normas dispositivas que la regulan se encuentran dispersas y presentan, en algunos casos, aparentes antinomias o lagunas.

Veremos, entonces, cada uno de los supuestos arriba enunciados para ir despejando el régimen propio de cada una de las vías de regreso a que dan lugar:

\section{Supuestos del pago de un tercero, 2: Pago del tercero CON EFECTO SUBROGATORIO}

Hemos dicho que junto al interés del tercero en el cumplimiento de la obligación es también un factor determinante, no de la legitimación del ter-

${ }^{81} \mathrm{He}$ empleado esta denominación porque estimo que es la que más se ajusta a su fundamento y contenido, sin perjuicio de utilizar también las expresiones in rem verso, condictio de regreso u otras que emplean los autores. Con esto adelanto mi opinión que justificaré más adelante en el trabajo.

${ }^{82}$ Serra Callejo, Javier, Consideraciones sobre los efectos del pago de tercero, en Diario La Ley, 2 (1991), p. 1082. También Gómez-Blanes, Pablo, cit. (n. 68), p. 2830. 
cero, sino de los efectos de su pago, el hecho de contar o no con la voluntad de las partes de la relación obligatoria. Ello es así toda vez que, siendo dueñas de su relación pueden celebrar los pactos que estimen dentro del amplísimo margen en que la autonomía de la voluntad puede operar.

Considerando este factor y el hecho que el tercero se encuentra legitimado para pagar, se producirá el efecto subrogatorio de su pago cuando, sin importar el interés que lo motive, cuente con la voluntad conforme del acreedor o del deudor. En el primer caso, nos encontraremos frente a la subrogación convencional, es decir, aquella que opera en virtud de una convención entre el acreedor y el solvens (artículo 1611 CC.) y en el segundo, frente a la subrogación legal prevista en el No 5 del artículo $1610 \mathrm{CC}^{83}$.

Ahora bien, dejando de lado la voluntad conforme del acreedor o del deudor, considerando sólo el punto de vista del interés que puede motivar al tercero a pagar, nuestra ley distingue los casos en que el solvens actúa sobre la base de un interés personal en el pago de la obligación y aquellos en que no concurre tal interés. Al efecto, coloca en situación privilegiada, respecto de los efectos de ese pago, al tercero que ostenta un interés personal en el pago: le concede el beneficio de la subrogación.

Por medio de la subrogación se obtiene la transmisión de los derechos del acreedor pagado al tercero que le pagó (artículo 1608 CC.). Es claro que no se trata de una verdadera transmisión de derechos, pero el vocablo fue utilizado para descartar la idea de transferencia o cesión que implican la voluntad del acreedor, lo que no se compadece con la subrogación legal ${ }^{84}$. Son conocidas las críticas a la definición del Código, que sólo apunta a los efectos del instituto ${ }^{85}$, sin embargo del propio término subrogación se desprende que lo que se produce en el pago con efecto subrogatorio es la sustitución de una persona-acreedor originario- por otra - un tercero- que le paga y que la reemplaza ocupando su sitio y lugar para ejercitar sus derechos y acciones ${ }^{86}$. El subrogado podrá, entonces, entablar todas las acciones derivadas del crédito pagado con el fin de obtener el reintegro, "[...] así contra el deudor principal como contra cualesquiera terceros, obligados solidaria o subsidiariamente a la deuda" ${ }^{87}$. Desde el punto de vista procesal, será considerado parte, en reem-

${ }^{83} \mathrm{La}$ voluntad conforme del deudor se refiere al pago mismo hecho por el tercero, siendo la ley la que dispone el efecto subrogatorio, mal podría referirse a querer subrogar al tercero transmitiéndole el crédito del cual no es dueño.

${ }^{84}$ Claro Solar, Luis, cit. (n. 19), p. 220.

${ }^{85}$ Abeliuk Manasevich, René, cit. (n. 7), p. 598.

${ }^{86}$ Claro Solar, Luis, cit. (n. 19), p. 212. En pp. 214-227 expone las diferentes teorías acerca del fundamento y naturaleza jurídica de la subrogación, a las que me remito ya que su análisis escapa a los límites de este trabajo.

${ }^{87}$ Artículo 1612 CC. 
plazo del acreedor subrogante y no tercero ${ }^{88}$. En palabras de Alessandri, "ha cambiado así la persona, el ser material, pero el ser jurídico, el acreedor, el sujeto activo del derecho, es el mismo" y citando a Leopoldo Urrutia, agrega "como si el subrogado obrara poniéndose la máscara del subrogante" ${ }^{99}$. Basta el hecho del pago y su prueba legal para que opere la subrogación, sin necesidad de hacer valer otros medios probatorios para acreditar la subrogación ${ }^{90}$. Nuestra jurisprudencia ha sido clara al sostener que "produciéndose el hecho del pago, opera la subrogación legal, y ésta habilita al subrogante a accionar como si fuera el subrogado, pudiendo, por lo tanto, entablar las acciones que le parezca pertinentes"91.

El $\S 8$ del título $14^{\circ}$ trata del pago con subrogación, definiéndola como la "transmisión de los derechos del acreedor a un tercero, que le paga". La subrogación puede ser legal o convencional, produciendo ambas los mismos efectos: el traspaso al nuevo acreedor de todos los derechos, acciones, privilegios, prendas e hipotecas del antiguo, así contra el deudor principal, como contra cualesquiera terceros, obligados solidaria o subsidiariamente a la deuda (artículo 1612 CC.). El efecto principal, consistente en la no extinción de una obligación que fue pagada, evidentemente parece forzar la lógica jurídica pero, como reconoce la mayoría de los autores, ello es así en aras de las necesidades del tráfico, constituyendo un importante estímulo de la ley a la circulación de los créditos ${ }^{92}$.

Para saber de qué manera la ley ha considerado el interés del tercero, independientemente de la voluntad de las partes, reforzando la legitimación para el pago, es necesario el estudio y análisis del artículo 1610, que dispone el efecto subrogatorio en atención a ese sólo interés. La citada disposición establece que "[S] e efectúa la subrogación por el ministerio de la ley y aun contra la voluntad del acreedor, en todos los casos señalados por las leyes, y especialmente a beneficio, [...]" de ciertos terceros que enumera. El efecto de operar por el

${ }^{88}$ Por ello se ha fallado que el subrogado que reemplaza al acreedor en juicio no requiere intervenir mediante una tercería, basta que acredite la subrogación para que se desplieguen los efectos que contempla el artículo 1612 CC. Véase Corte Suprema, 27 de agosto de 1992, LegalPublishing No 11.987.

${ }^{89}$ Alessandri Rodríguez, Arturo, Del traspaso del derecho de hipoteca en el pago con subrogación, en Revista de Derecho y Jurisprudencia, 20 (1924), sec. "Derecho", p. 10 .

${ }^{90}$ Corte Suprema, 26 de noviembre de 1991, LegalPublishing No 11.719.

${ }^{91}$ Corte Suprema, 29 de septiembre de 2004, rol No 1127-2004, en Fallos del Mes, 526, p. 2078.

${ }^{92}$ Según Colin, Ambroise - Capitant, Henri, Cours élémentaire de Droit civil (10ª edición, París, Dalloz, 1948) II, p. 369, la subrogación es una de las instituciones que presentan esos "conflits qui s'èlévent assez frequemment entre la logique juridique et les nécessités de la vie $[. .]$.$” .$ 
sólo ministerio de la ley implica que se puede imponer al acreedor, al deudor y a ambos, con lo que la legitimación es verdaderamente amplia ${ }^{93}$.

Esta nota de la subrogación legal tiene interés en la sistemática del pago de tercero por cuanto deja fuera toda consideración de la voluntad de las partes. Tiene, además, la implicancia adicional de descargar al tercero de la necesidad de advertir que se va a subrogar por el pago ${ }^{94}$.

A diferencia de lo que ocurre en otras codificaciones, como en la francesa y la española, no contiene el Código una disposición abierta que ordene la subrogación del tercero interesado, sino que enumera los casos en que el tercero se subroga legalmente, tanto en el artículo 1610 CC., como en otras disposiciones, lo que, de alguna manera, evita toda discusión respecto del interés que pueda alegar el solvens y su mérito subrogatorio ${ }^{95}$. En todo caso, resulta clara y aplicable al artículo en comento, la observación de Planiol y Ripert en cuanto: "[...] todos estos casos reposan en la idea de un convenio

${ }^{93}$ Demolombe, Jean Charles Florent, cit. (n. 22), p. 386-392.

${ }^{94} \mathrm{Sin}$ embargo y a pesar que el antecedente inmediato de estas disposiciones lo encontramos en idénticos términos en el Código Civil francés, no fue pacífica la discusión doctrinal anterior a la codificación. Pothier, Robert Joseph, Tratado de las obligaciones (s/trad., Barcelona, Imprenta y Litografía de J. Roger, 1839), p. 297, era de la opinión que el tercero debía pedir la cesión de las acciones al pagar, es decir, que la subrogación se producía previa réquisition al acreedor, aunque dejaba en claro la opinión en contra de Dumoulin, que fue finalmente la tesis acogida por el Code y por el Código chileno. Lo anterior, sin perjuicio que el antecedente más remoto de la subrogación podría encontrarse en el beneficium cedendarum actionum que el Derecho Romano otorgaba al fiador y en la successio in locum creditoris que se otorgaba al acreedor hipotecario. No obstante, en términos más modernos, como se conoce hoy en día la subrogación, sus antecedentes se encuentran en el Derecho intermedio francés, en un edicto de Enrique IV, de 1609, que autorizó a ciertos deudores a interés para subrogar al tercero que le prestaba dinero a un interés menor al original, normativa que en 1690 se hizo extensiva a todos los deudores mediante la Arreté des subrogations; véae: CLARO SolAR, Luis, cit. (n. 19), p. 226. Este es el antecedente de la subrogación ex mutuo regulada en nuestro artículo 1610 No 6 CC. En todo caso, tratándose de la subrogación del tercero que paga con aprobación expresa o tácita del deudor, su origen se ubica concretamente en el Derecho mercantil francés, en la Ordenanza del Comercio Terrestre, de 1673, aplicable en materia de letras de cambio y pagarés; véae: BAYo RECUERO, Nieves, cit. (n. 27), pp. 121-131.

${ }^{95}$ Señala el artículo 1251 CCFr.: "La subrogation a lieu de plein droit:...3 $3^{\circ}$ Au profit de celui qui, étant tenu avec d' autres ou pour d' autres au paiement de la dette, avait intérêt de lacquitter." En iguales términos, el CCIt. dispone, en su artículo 1203: "La surrogazione ha luogo di diritto nei seguenti casi: $3^{\circ}$ a vantaggio di colui che, essendo tenuto con altri o per altri al paggamento del debito, aveva interesse di sodisfarlo." Por su parte el artículo 1210 CCEsp. dispone: "Se presumirá que hay subrogación: $3^{\circ}$ Cuando pague el que tenga interés en el cumplimiento de la obligación, salvos los efectos de la confusión en cuanto a la porción que le corresponda." 
sobreentendido. En determinadas circunstancias la persona que paga por otro se ve legalmente obligada a ello o bien existe un considerable interés, bien para ella, bien para el deudor, en que pague en lugar de éste. Deseosa la Ley de que este pago por otro se realice, sobreentiende, para facilitarlo, la subrogación que concede de oficio" $"$.

¿Quiénes son estos terceros que se subrogan legalmente? Hemos dicho que su ubicación se encuentra dispersa en el Código, a ella se refieren los artículos 1366, 1610, 2295, 2372 y 2429 , entre otros; sin considerar que existen casos de subrogación que operan legalmente pero no en virtud de un pago, como ocurre en los artículos 1677, 1965, 1968 y 2231 CC.; son simplemente otros casos de subrogación personal que no vienen al caso.

Nos remitiremos solamente a los casos de subrogación legal por pago que se encuentran mencionados en el artículo 1610, sin perjuicio de referirnos a algún otro que, por su semejanza, se ha considerado pertinente tratar. Todos ellos se aplican a un tercero que o tiene algún grado de participación en la deuda, porque responde de ella solidaria o subsidiariamente, o la subsistencia de su derecho depende del pago de la misma, sea porque es poseedor de la cosa afecta a la obligación o porque tiene constituido sobre ella algún derecho real. En definitiva, está sujeto o podría llegar a estarlo, en forma personal o real, al poder de agresión del acreedor y por ello se encuentra en la necesidad jurídica de cumplir.

a) El acreedor que paga a otro acreedor de mejor derecho en razón de un privilegio o hipoteca ${ }^{97}$. El acreedor que paga a otro de mejor derecho no obtiene por medio de la subrogación que su crédito pase a gozar de las garantías y privilegios del crédito del acreedor pagado, ni tampoco el rango de ese crédito. Conserva su derecho en las mismas condiciones que antes del pago pero, además, incorpora a su patrimonio el crédito que ha pagado, con lo cual refuerza su posición dentro del patrimonio del deudor mejorando sus expectativas de satisfacción.

El interés de este acreedor de grado posterior consiste precisamente en subrogarse en los derechos del acreedor preferente a fin de asegurarse el cumplimiento íntegro de su crédito por parte del deudor. Lo que persigue es mejorar su grado o rango dentro de los acreedores del deudor para no perjudicar su crédito y así poder esperar un mejor momento para ejecutarlo, evitando una ejecución intempestiva y disminuyendo, de paso, los gastos del pago por

${ }^{96}$ Planiol, Marcel - Ripert, Georges J., Tratado práctico de Derecho civil francés. Las Obligaciones (trad. M. Díaz Cruz y E. Le Riverend Brusone, La Habana, Cultural, 1945), VII, $2^{\circ}$, p. 564.

${ }^{97}$ Esta norma es igual a la contenida en los artículos 1251 № 1 del CC. francés y $1210 \mathrm{~N}^{\circ} 1$ del CC. español, aunque un poco más escueto este último ya que no expresa la razón de la preferencia. 
la reducción de partes interesadas. En todo caso, no se perjudica al acreedor pagado, quien recibe en pago todo lo que se le debía, tampoco se perjudica al deudor, sino al contrario, el interés del subrogado se compatibiliza mejor con sus derechos que el del subrogante toda vez que aquél podía ejecutar al deudor sobre la finca en un momento que esta alcanzara un precio inferior, suficiente para pagar su acreencia solamente sin contemplación respecto de los demás acreedores; el subrogado, en principio, velará por el momento en que la ejecución pueda alcanzar a cubrir más créditos del deudor ${ }^{98}$.

No requiere este solvens que el acreedor consienta, así como tampoco que le haga la tradición del derecho real de hipoteca, la subrogación por sí sola traspasa el crédito y todos sus accesorios ${ }^{99}$. Dos autores nacionales se han pronunciado en este sentido al comentar y criticar sendos fallos emanados de la Corte Suprema en que se desconoció la calidad de acreedor hipotecario al subrogado que no inscribió el pago con subrogación al margen de la hipoteca, fundados básicamente en las disposiciones de los artículos 686 y 2410 CC. ${ }^{100}$. No obstante y sin perjuicio de lo anterior, es de estimar que, por razones de orden práctico, tenga ventaja subinscribir el pago con subrogación al margen de la inscripción hipotecaria, así se conoce quien es el acreedor y éste se evita cancelaciones fraudulentas o en perjuicio suyo ${ }^{101}$. Asimismo, la hipoteca que

\footnotetext{
${ }^{98}$ Idea que desarrolla Claro Solar, Luis, cit. (n. 19), pp. 233 y 234, al tratar este caso de subrogación legal.

${ }^{99}$ Por todos, Abeliuk Manasevich, René, cit. (n. 7), p. 615; y Alessandri Rodríguez, Fernando, La hipoteca en la legislación chilena (Santiago, Soc. Imprenta y Litografía Universo, 1919), pp. 331 y ss.

${ }^{100}$ Claro Salas, Héctor, Un caso de pago con subrogación, en Revista de Derecho y Jurisprudencia, 8 (1911), 1 a parte, "Derecho", pp. 170 y 171. Señala este autor que "no cabe la idea de una tradición que no podría tener lugar sin la voluntad del acreedor" y como se ha dicho, la subrogación legal opera aún contra su voluntad. Agrega que, de requerirse inscripción conservatoria, la hipoteca tendría la fecha del pago y no la fecha original de que gozaba el subrogante, con lo que el subrogado se vería imposibilitado para ejercitar su derecho contra un acreedor hipotecario de fecha anterior al pago con subrogación. Por su parte, Alessandri RodRíGUeZ, Arturo, cit. (n. 89), p. 13, agrega que, requiriendo la tradición de un título traslativo de dominio ( 675 CC.) y no siendo el pago con subrogación uno de ellos, puesto que es un acto jurídico que extingue obligaciones y se perfecciona por la sola voluntad del que paga, no habría título por el cual hacer la tradición.

${ }^{101}$ Ibíd., p. 17, con abundante cita de doctrina extranjera. Véase también RuBio GARrido, Tomás, cit. (n. 74), pp. 113-120, sobre la situación en el derecho español, en que hubo de dictarse la Ley de Subrogación y Préstamos Hipotecarios, de 1994, que ordena la publicidad de la subrogación operada en virtud de ella mediante la inscripción de una nota marginal en el Registro de Hipotecas. El autor llega a las mismas conclusiones apuntadas para el derecho chileno y agrega que es aplicable al caso la regulación del pago hecho al acreedor aparente [artículo 1576 , inciso $2^{\circ} \mathrm{CC}$.].
} 
garantizaba el crédito pagado sigue siendo accesoria al mismo y no puede pretenderse que ella caucione otros créditos que el tercero pudiere tener en contra del deudor, distintos al que dio origen a la subrogación ${ }^{102}$. Queda así sumamente claro que la subrogación no importa novación de la deuda, ni el crédito ni sus garantías sufren la menor alteración, precisamente porque la deuda no se ha extinguido pasivamente mediante el pago ${ }^{103}$.

Si el pago efectuado es parcial y ha sido aceptado por el acreedor, se puede igualmente paralizar las gestiones ejecutivas, por lo que también tendrá sentido para el tercero realizar este pago y la ley le concede asimismo la subrogación ${ }^{104}$. El artículo 1612 se refiere al caso de la subrogación parcial, sea legal o convencional, los efectos son los mismos: el acreedor pagado conserva su derecho para perseguir el saldo, con preferencia al subrogado. No se establece entre ambos un caso de co-acreencia de obligación indivisible, que pudiera hacer aplicable el artículo 1526 CC. -en que el acreedor pagado en su parte no pudiese remitir la prenda o cancelar la hipoteca mientras no se hayan satisfecho sus co-acreedores-, sino que cada acreedor es independiente para cobrar su crédito.

b) El que habiendo comprado un inmueble, es obligado a pagar a los acreedores a quienes el inmueble está hipotecado.

En este caso se trata del adquirente de un bien que se encuentra hipotecado para garantía de una deuda anterior. Si bien este sujeto no es deudor, responde de la deuda hasta el límite establecido y sólo con la finca hipotecada.

Los autores se preguntan si el caso es aplicable a cualquier título que se haya adquirido el inmueble o sólo a la compraventa, ya que la ley se refiere sólo a esta última. Claro Solar se inclina por estimar que sólo se refiere al adquirente por compraventa, fundado en el antecedente inmediato de la norma, artículo $1251 \mathrm{~N}^{\circ} 2$ del CCFr. ${ }^{105}$. En este sentido se inclina nuestra jurisprudencia, al establecer que "...la subrogación se opera a favor del 'comprador' de un inmueble hipotecado; la adquisición debe verificarse, pues, a

${ }^{102}$ Corte Suprema, 21 de enero de 2003, en Legal-Publishing No 25.996.

${ }^{103}$ Por lo demás, así han fallado nuestros tribunales, al sostener que es improcedente la alegación de que la preferencia carece de la inscripción conservatoria hipotecaria a favor del tercero, toda vez que la citada no es un requisito o solemnidad determinada expresamente por la ley. Véase la sentencia confirmatoria de la Corte de Apelaciones de Santiago, 4 de abril de 2002, en LegalPublishing No 25.996.

${ }^{104}$ Corte Suprema, 14 de noviembre de 1913, en Revista de Derecho y Jurisprudencia, 21 (1924), $2^{\text {a }}$ parte, sec. $1^{\text {a }}$, p. 149, citada por Claro Solar, Luis, cit. (n. 19), p. 239.

${ }^{105}$ En él se emplea el término adquisición, lo que podría indicarnos amplitud en el título, sin embargo, luego se refiere al precio con el que el tercero debe pagar al subrogante, lo que conduce necesariamente a la compraventa. 
título de compraventa. No exige la ley, en cambio, que el comprador haya aplicado al pago de los créditos hipotecarios el precio de la compraventa"106. En efecto, a pesar de la similitud con el Code Civil, el chileno no exige que el tercero haya pagado al acreedor hipotecario con el precio de la venta sino que la subrogación operará cualquiera sea el origen de los dineros con que lo haya hecho, mientras sean suyos ${ }^{107} \mathrm{y}$ aunque ya hubiese pagado el precio al vendedor ${ }^{108}$.

Cabe atender con relación a este supuesto, al del tercer poseedor de la finca hipotecada que paga al acreedor hipotecario; a pesar de su similitud con el caso del artículo $1610 \mathrm{~N}^{\circ} 2$, se le ha dado un tratamiento singular por motivos históricos ${ }^{109}$. Para que se trate del pago de un tercero -deuda ajenaes necesario que la hipoteca la haya constituido un tercero para garantizar una obligación ajena, respecto de la cual es un extraño. Por ello, "la acción que el acreedor siga en contra del tercer poseedor de la finca hipotecada sólo puede tener por objeto la realización de la cosa raíz hipotecada para caucionar la obligación del deudor personal, con la consecuencia de que no procede perseguir en todo el patrimonio de ese tercero el cumplimiento de esa obligación" ${ }^{110}$. Conforme al artículo 2429 inciso $2^{\circ}$ CC., haciendo el pago se subroga en los derechos del acreedor en los mismos términos que el fiador. En igual situación se ubica el que ha hipotecado un inmueble suyo para garantizar una obligación ajena, sea que además se haya obligado per-

${ }^{106}$ Corte Suprema, 15 de octubre de 2009, en LegalPublishing No 42.846.

${ }^{107}$ Cfr. Meza Barros, Ramón, Manual de Derecho Civil. De las Obligaciones (10 ed. actualizada, Santiago, Editorial Jurídica de Chile, 2007), p. 192.

${ }^{108}$ En contra: Alessandri Rodríguez, Arturo, Teoría de las obligaciones. Derecho civil, $2^{\circ}$ año, versión taquigráfica de sus clases por Ramón Latorre $Z$. (Santiago, Zamorano y Caperán, 1934), p. 360, quien se inclina por la doctrina francesa y exige que el pago se haya efectuado con el precio de la compraventa. Lo que no puede ocurrir es que se pague con los dineros de la venta recibidos por el vendedor pues en ese caso se ha hecho dueño del dinero y queda fuera del supuesto de hecho.

${ }^{109}$ Antes de la codificación francesa no existía la subrogación legal para el obligado solidario o subsidiario y en cambio sí la había para el tercer poseedor y el adquirente de la finca hipotecada, desde el Derecho Romano se les concedía la successio in locum creditoris. Por esta razón, en la codificación se estimó que de haberse omitido su mención en la norma se habría prestado para interpretar que el legislador quiso suprimirla. Véase: Claro Solar, Luis, cit. (n. 19), XII, p. 244.

${ }^{110}$ Así se falló en el caso de un acreedor hipotecario que interpuso en contra de un tercer poseedor hipotecario demanda de desposeimiento y además, demanda ejecutiva, frente a la cual se opuso la excepción del artículo 464 № 7 CPC, que fue acogida por la Corte Suprema, casando la sentencia, por estimar que no procedía perseguir en todo el patrimonio de ese tercero el cumplimiento de la obligación. Corte Suprema, 8 de agosto de 2005, en Fallos del Mes, 536 (2005-2006), pp. 1893 ss. 
sonalmente o no, ya que el artículo 2430 inciso $2^{\circ} \mathrm{CC}$., le confiere derecho a subrogarse cuando paga, de igual forma que el fiador ${ }^{111}$.

El interés que ostentan estos terceros radica en querer conservar la posesión del inmueble evitando, mediante el pago, la subasta del mismo. Por este motivo su interés en el cumplimiento es directo: para evitarse los medios coactivos del acreedor. Se ha dicho, me parece que con razón, que la intervención de este tercero en el pago responde al concepto de "carga", toda vez que paga al acreedor requirente a fin de excluir un perjuicio jurídico (pérdida de la finca hipotecada) no provocado por él mismo ${ }^{112}$.

El efecto subrogatorio de estos pagos consistirá en la no extinción de la hipoteca, que pasará a garantizar al subrogado por el crédito pagado y así le asegura su reembolso. El solvens se asegura, además, la libre posesión del inmueble. Sin embargo, en estricta lógica jurídica, cabría preguntarse ¿cuál es la ventaja de subrogarse si es dueño del inmueble que garantiza su crédito? Se trataría de un acreedor hipotecario de su propio inmueble. La respuesta es más bien de orden práctico, por una parte, la utilidad de la subrogación se presenta toda vez que subsistan acreedores hipotecarios que no fueron satisfechos y además, como advierte Claro Solar, la norma está pensada no para una situación inalterable en el tiempo sino para gozar del carácter real de la garantía si es que se pierde la posesión de la finca ${ }^{113}$. Debe considerarse, además, que la ley no exige que el comprador haya adquirido el dominio, podría tratarse de una adquisición a non domino y en este caso la subrogación le será útil al solvens frente a la reivindicatoria del dueño. También puede ocurrir que se presente un acreedor hipotecario no considerado o del que no se tuvo noticia, o frente a una acción de resolución o nulidad por la que pudiera perder el inmueble. De este modo, no se pierde al mismo tiempo el inmueble y el precio. Al efecto, la jurisprudencia ha sostenido que " $[\mathrm{L}] \mathrm{a}$ justicia moral del precepto señalado es ostensible. Merced a él se conservan las hipotecas establecidas en las propiedades que se enajenan, en beneficio de los que las han comprado, a objeto de resguardar el capital que se ha invertido en ellas de los perjuicios que puedan sobrevenir a consecuencia de las posibles evicciones futuras que, por ausencia del amparo legal de dicho № 2, daría margen a que la fortuna de los que ejercitan las acciones encaminadas a aquel

${ }^{111}$ El hecho que el Código establezca la subrogación “[...] en los mismos términos que el fiador" ha llevado a algunos autores a tratar estos casos sobre la base del artículo 1610 No 3 CC. Véase LARraín Ríos, Hernán, Teoría general de las obligaciones (Santiago, LexisNexis, 2002), pp. 365-367.

${ }^{112}$ Rotondi, Mario, Instituciones de Derecho privado (trad. Francisco Fernández, Barcelona, Labor, 1953), p. 86.

${ }^{113}$ Claro Solar, Luis, cit. (n. 19), pp. 241 y 242. 
fin prosperara a expensas del respectivo adquirente, sin la concurrencia de ninguna causa que contribuyera a legitimar semejante resultado"114.

$\mathrm{Al}$ igual que en el caso anterior, si el crédito hipotecario cubierto por el tercer poseedor era mayor, subsistiendo una parte de la deuda, se producirá la subrogación parcial, por lo que me remito a lo expuesto.

Ahora bien, si el acreedor se da por satisfecho con una cantidad menor, debe tenerse presente que el efecto de la subrogación persigue evitar un perjuicio injusto al tercero, más su interés en el cumplimiento no lo legitima para obtener un enriquecimiento reclamando lo que no ha desembolsado. En todo caso, para entender que ha habido una remisión parcial del crédito tendría que haberse hecho expresamente. Es distinta la situación en la cesión de derechos, en que el cesionario puede cobrar el valor nominal del crédito al deudor, independientemente de la suma desembolsada para adquirirlo.

El deudor podrá oponer al solvens todas las excepciones derivadas de su relación obligatoria con el acreedor, que hubieren sido válidas respecto del subrogante. Esto es evidente desde el momento que el pago del tercero no puede implicar un menoscabo en su posición jurídica frente a la obligación o implicarle un mayor gravamen. Así, por ejemplo, podrá el deudor oponer la prescripción que hubiera empezado a correr en contra del subrogante, ya que los plazos de prescripción no se alteran por la subrogación.

En estos casos de subrogación, el tercero es verdaderamente un obligado o responsable de la obligación, ya que en su calidad de tercer poseedor de la finca hipotecada viene obligado en forma subsidiaria. Si bien el artículo 2429 le priva expresamente del beneficio de excusión ${ }^{115}$, si el deudor no paga a su acreedor hipotecario el tercero será desposeído, por ello, para evitarlo, paga y la ley igualmente lo entendería subrogado en virtud del No 3 del artículo 1610, que se refiere precisamente a los que se hallan obligados subsidiariamente, con lo que se da una verdadera repetición normativa ${ }^{116}$.

c) El que paga una deuda a que se halla obligado solidaria o subsidiariamente. En sus orígenes, esta clase de subrogación no operaba por el sólo ministerio de la ley, tanto el codeudor solidario como el fiador, típico deudor subsidiario, tenían derecho a la subrogación pero debían exigirla al momento de efectuar el pago. No habiendo ley que otorgara la subrogación legal, esta era la idea que imperaba entre los tratadistas franceses anteriores

${ }^{114}$ Corte Suprema, 31 de marzo de 1936, en Gaceta Jurídica, 12 (1936), $1^{\circ}$ sem., p. 102 ss.

${ }^{115} \mathrm{El}$ artículo $2429 \mathrm{CC}$. dispone, en su inciso $1^{\circ}$ : "El tercer poseedor reconvenido para el pago de la hipoteca constituida sobre la finca que después pasó a sus manos con este gravamen, no tendrá derecho para que se persiga primero a los deudores personalmente obligados".

${ }^{116}$ Véase la nota 109. 
al Code $e^{117}$, sin embargo, contra la opinión de estos tratadistas, se impuso la doctrina de Dumoulin, que pasó después a la codificación ${ }^{118}$.

i) El codeudor solidario. Hemos dicho que el codeudor solidario se estudia bajo la disciplina del pago de tercero en cuanto se lo considera como deudor no exclusivo, por aquella parte de la obligación satisfecha que no le incumbía, que le era ajena. Sin esta prevención, tendríamos que decir que el codeudor solidario es deudor de la obligación ${ }^{119}$. Para el acreedor es tan deudor que puede exigir el cumplimiento íntegro de la obligación de cualquiera de sus codeudores solidarios (artículo $1514 \mathrm{CC}$ ) y el pago íntegro realizado por cualquier codeudor extingue la obligación para todos respecto del acreedor, lo que se explica por la pluralidad de vínculos y la unidad de la prestación que rige en toda obligación solidaria ${ }^{120}$. Es importante destacar que el pago de la obligación solidaria debe ser íntegro para dar lugar a la vía de regreso, ya que, como acertadamente han fallado nuestros tribunales, "mientras la obligación solidaria pactada por las partes no se encuentre extinguida, lo cual sólo ocurre con su pago total al acreedor, no puede dividirse la deuda entre los codeudores solidarios porque mientras quede un saldo por pagar, son obligados al total del remanente insoluto respecto del acreedor ${ }^{121}$.

En este supuesto subrogatorio, se da la particularidad de que el codeudor que paga la deuda, paga deuda propia y deuda ajena al mismo tiempo, por esta razón se subroga en los derechos del acreedor y es en este sentido que corresponde a la figura de pago de tercero ${ }^{122}$. En doctrina suele citarse

${ }^{117}$ Sólo la Coutume de Bretagne acogía la subrogación ex lege en estos casos, pero no el resto de los ordenamientos franceses anteriores al Code. Véase Claro Solar, Luis, cit. (n. 19), p. 247.

${ }^{118}$ El artículo 1251 No 3 CCFr. habla del que estando obligado con otros o por otros a la deuda, tenía interés en satisfacerla, con lo que se refiere al codeudor solidario y al fiador. A su vez, el artículo 1210 No 3 CCEsp. dice: "cuando pague el que tenga interés en el cumplimiento de la obligación, salvo los efectos de la confusión en cuanto a la porción que le corresponda."

${ }^{119}$ Somarriva Undurraga, Manuel, Tratado de las cauciones (2a edición, Santiago, Contable Chilena, 1981), pp. 75-76, llama la atención sobre este tipo de subrogación que cede a favor de un deudor directo y no de un tercero; pero ya hemos dicho que ello se explica por su carácter de deudor no exclusivo.

${ }^{120}$ Por todos: PeÑailillo Arévalo, Daniel, Obligaciones. Teoría general y clasificaciones. La resolución por incumplimiento (Santiago, Editorial Jurídica de Chile, 2003), p. 254.

${ }^{121}$ Corte de Apelaciones de Antofagasta, 30 de octubre de 2007, en LegalPublishing, No 37.594. Esta sentencia rechazó, por falta de oportunidad, el ejercicio de la acción de reembolso de un codeudor solidario que pagó parte de la deuda, existiendo aún un saldo pendiente, con lo que confirma que la subrogación del codeudor solidario requiere el pago total de la deuda al acreedor originario.

${ }^{122}$ Particularmente, en el caso del codeudor solidario la subrogación se produce no 
a Pothier utilizando las palabras de Demolombe, que ilustran la especial legitimación del codeudor solidario y del fiador, en tanto pueden imponerle al acreedor la siguiente disyuntiva: "o nos liberas o nos subrogas ${ }^{123}$. Siempre, entonces, que hay solidaridad pasiva existe un interés propio del codeudor en el pago ya que si paga extingue la deuda con el acreedor, respecto de quien está directamente obligado. El efecto extintivo opera, en este caso, con un alcance limitado, ya que no es deudor exclusivo: si bien se extingue la deuda respecto del acreedor, ésta subsiste entre el codeudor que paga y el resto de los codeudores por efecto de la subrogación. No ocurre lo mismo cuando la obligación de varios deudores es simplemente conjunta o mancomunada, ya que el codeudor en este caso no tiene responsabilidad, ni siquiera indirecta, en la deuda de sus codeudores, de modo que si paga más de lo que corresponde a su cuota actúa como un tercero extraño y no se produce en su beneficio la subrogación legal, salvo en cuanto haya actuado con el consentimiento de sus codeudores, ex artículo 1610 № 5 CC.

Teniendo en cuenta que la subrogación no crea una nueva obligación sino que se trata del mismo crédito, que subsiste, el solvens tendrá la misma acción derivada de la deuda pagada para dirigirse en contra del resto de sus codeudores reclamando a cada uno su cuota según el pacto o el interés en la obligación, en la etapa de contribución a la deuda ${ }^{124}$. La subrogación que opera en este caso, entonces, tiene un efecto limitado, atendido lo dispuesto en el inciso $1^{\circ}$ del artículo $1522 \mathrm{CC}$. y así lo han declarado expresamente los tribunales al fallar en el denominado "caso Beraud" lo que sigue: "[...] la subrogación que en la especie operó, en virtud del pago que el Fisco hiciera en su oportunidad en su calidad de codeudor solidario, reconocía como limitación lo establecido en el artículo 1522, inciso primero, del Código Civil [...], de modo tal que el demandante no pudo dirigirse por el total contra los otros deudores solidarios sino a prorrata de las cuotas que les corresponden" ${ }^{25}$. No sería justo

sólo como efecto del pago sino también de otros modos de extinción equivalentes, tales como la dación en pago, la compensación, la novación o la confusión.

${ }^{123}$ Ibíd., p. 173. Cabe por cierto, hacer la salvedad de que para Pothier y la doctrina de su época la subrogación de estos terceros operaba previo requerimiento al acreedor.

${ }^{124}$ Originariamente, en el Proyecto de Código Civil (1841-1845) publicado en El Araucano, se optó por el criterio de Dumoulin que permitía al solvens repetir el total en contra de cualquier codeudor deduciendo sólo su cuota. Obras completas de don Andrés Bello (Santiago, Imprenta de Pedro G. Ramírez, 1887), XI, p. 157.

${ }^{125}$ Corte Suprema, 12 de junio de 2007, en LegalPublishing No 36.492. Esta sentencia ha sido comentada por el profesor Pizarro, Carlos, en Aguad Deik, Alejandra - Pizarro Wilson, Carlos, Comentarios de jurisprudencia. Obligaciones y responsabilidad civil, en Revista Chilena de Derecho Privado, 14 (julio de 2010), pp. 175-178. El fallo estimó que el Fisco pagador debió dirigirse en contra de cada uno de sus codeudores por su cuota en la deuda, en circunstancias que, por no ser un interesado en la deuda 
que el deudor que pagó conserve la solidaridad frente a sus iguales y desde un punto de vista práctico, la ley ha querido evitar una cadena de juicios entre los diversos codeudores ${ }^{126}$. Por lo demás, la solidaridad es una modalidad expresamente pactada en la relación obligatoria entre los deudores y el acreedor, que la subrogación no tiene la virtualidad de incorporar en las relaciones personales entre los deudores; en otras palabras: " $[\mathrm{L}] \mathrm{a}$ acción del subrogante [el solvens, a quien hemos denominado subrogado] es por una obligación simplemente mancomunada; la del subrogado, el acreedor, era por una solidaria"127.

Para estos efectos, se vuelve sobre el interés de cada uno de los deudores en la obligación, de modo que:

Si el codeudor que realizó el pago no tenía interés en la obligación no debe en definitiva contribuir a la deuda y por ello la subrogación será total, es decir, podrá dirigirse en contra del resto de los codeudores interesados por el total de la deuda, considerándolo la ley como un fiador (artículo 1522, inciso $2^{\circ} \mathrm{CC}$.). Esta situación presenta dos consecuencias, por una parte, si el pago lo realizó un codeudor interesado nada puede exigir en vía de regreso al codeudor no interesado, que es tenido como fiador (se libera por el pago efectuado por el deudor principal) y por otra, si el pago lo efectuó el codeudor no interesado, se reembolsa según lo hace el fiador, esto es, aplicando el artículo 2372 CC., podrá ejercer la acción de reembolso del artículo 2370 CC., por los conceptos allí indicados. El artículo 2372 CC. distingue según si la fianza se ha prestado respecto de varios deudores principales solidarios o sólo respecto de alguno de ellos, de modo que, concurriendo en este caso la primera situación descrita, cuando ha pagado el codeudor solidario no interesado (fiador) puede demandar a cada uno de sus codeudores interesados el total de la deuda.

Si hay más de un codeudor no interesado, también se aplica, por remisión, la norma de la fianza que regula la situación de los cofiadores, artículo 2378 CC. El caso se presentará, normalmente, cuando el solvens no pueda dirigirse en contra de los codeudores interesados, sea por insolvencia u

se le debió considerar como fiador y por ello los artículos 1522 inciso $2^{\circ}$ y 2372 inciso $1^{\circ}$ CC. le permiten dirigirse en contra de cada uno por el total de la deuda, manteniendo la solidaridad. La sentencia, en cambio, aplica el inciso $1^{\circ}$ del artículo $1522 \mathrm{CC}$., pero sin ordenar la rebaja de la cuota del Fisco en la deuda, cosa que debió hacerse toda vez que dicha norma rige los reintegros entre codeudores interesados.

${ }^{126}$ Existe una excepción a esta regla, contenida en la Ley No 18.092 , sobre letras de cambio y pagarés, en su artículo 25 , inciso $1^{\circ}$, en que el pago por alguno de los endosantes concede la subrogación por el total de la deuda, ya que los endosantes son solidariamente responsables.

${ }^{127}$ Alessandri R., Arturo - Somarriva U., Manuel - Vodanovic, Antonio, cit. (n. 12), p. 154. 
otro inconveniente. El codeudor no interesado que pagó se subroga en los derechos del acreedor en contra de los otros codeudores no interesados, que son considerados cofiadores. En este caso, la cuantía de la subrogación será el exceso pagado por sobre su cuota, pues la deuda se divide entre los no interesados de igual manera que entre los cofiadores.

$\mathrm{Si}$, por el contrario, el solvens tenía interés, deberá descontar su cuota del reclamo y podrá cobrar a cada codeudor según su cuota.

La jurisprudencia ha sido bastante clara al pronunciarse sobre las relaciones internas entre deudores solidarios, así, ha establecido que "el pago es el hecho que da origen a la acción personal de reembolso del articulo 2370 CC., como además, a la acción subrogatoria prevista en el artículo $1610 N^{\circ} 3$ CC.; acciones que derivan de su doble calidad de codeudor solidario no interesado y por haber efectuado el pago, ya que en este evento ha pagado una deuda ajenay la ley le considera fiador [...]"128. También, que no debe confundirse el interés en la obligación de cada co obligado, unos por encontrarse en la necesidad jurídica de satisfacerla (frente al acreedor) y otros, por encontrarse obligados a sufrir en su patrimonio las consecuencias (entre deudores) ${ }^{129}$.

La cuantía a reclamar por el solvens corresponde al monto efectivamente pagado por él y no necesariamente al valor nominal del crédito. Si el acreedor recibe menos que el total de la deuda y consiente en ello, la remisión del saldo aprovechará al codeudor que la obtuvo, por lo que podrá dirigirse en contra de sus codeudores descontando lo remitido; si la remisión afectó al total de la deuda y no a algún codeudor en particular, el codeudor que pagó deberá descontar también lo remitido de las cuotas de sus codeudores al requerirlos en vía de regreso. Lo anterior se funda, básicamente, en que la subrogación no constituye una operación especulativa sino una medida favor debitoris ${ }^{130}$.

${ }^{128}$ Corte Suprema, 7 de mayo de 2007, en Fallos del Mes, 545 (2007), pp. 820 y ss. ${ }^{129}$ Ídem.

${ }^{130}$ Cfr. Claro Solar, Luis, cit. (n. 19), p. 223. Para la doctrina española, cfr. SANCho Rebullida, Francisco, Comentarios al Código Civil y Compilaciones Forales (2a edición, Madrid, Edersa, 1991), 16, 1º pp. 778 y 790-791; y Del Olmo García, Pedro, cit. (n. 73), pp. 218-232 y 310-311, fundado en la función accesoria de la subrogación, a pesar que tal idea pudiera dar origen a pensar que la subrogación traspasa sólo los accesorios del crédito en función de garantía del derecho de reembolso. Con todo, un importante sector de la doctrina española (Sancho Rebullida y Albaladejo, entre otros), considera que la subrogación convencional se rige en todo, por la cesión de derechos y admite, por lo tanto, que el subrogado pueda obtener del deudor el importe del valor nominal del crédito independientemente del monto pagado por él al subrogante. Claro Solar, Luis, cit. (n. 19), pp. 269-271, estima que las normas de la cesión de derechos aplicables a la subrogación convencional son sólo aquellas que ordenan la notificación al deudor, en todo lo demás difieren por cuanto la subrogación es ante todo, un pago. Es por ello que la remisión a la cesión sólo cumple el fin de operarse la 
Mas, esta opinión no es unánime, un sector de la doctrina estima que el tercero adquiere el crédito por su valor nominal más los intereses devengados y no satisfechos, si los hubiere, por lo que el solvens que obtuvo la remisión podría cobrar el total sin descontar la parte condonada. Se apoyan en el texto de la ley, que expresa que por la subrogación se traspasan al nuevo acreedor todos los derechos, acciones, privilegios, prendas e hipotecas del antiguo ${ }^{131}$. Se traspasa, entonces, el crédito con todas sus características, entre ellas su valor nominal. Consideran, además, que al admitirse el pago de tercero con efecto subrogatorio, la ley verdaderamente ha actuado favor creditoris, pues beneficia al que ha pagado ${ }^{132}$.

Nuestra jurisprudencia se inclina por estimar que la subrogación sólo permite adquirir el crédito por el importe de lo efectivamente desembolsado por el solvens. Así, en un fallo reciente desecha la solicitud de intereses por sobre el capital que pedía el subrogado, disponiendo que: "dicha acción subrogatoria tiene una amplitud limitada, al tener derecho a reclamar sólo el monto de lo que se ha pagado, si bien con igual poder adquisitivo mediante su reajuste, pero no puede pretender se le reconozca la posibilidad de obtener intereses de capital, pues ellos son ganancias, aspectos propios de los frutos civiles [...] que la ley no ha establecido para la subrogación, como tampoco constituye una obligación de crédito de dinero, conforme la define el artículo $1^{\circ}$ de la ley $18.010^{\prime 133}$. A ello no se opone, sin embargo, que si la deuda era productiva de intereses para el acreedor originario, corran ellos a favor del subrogado, puesto que así se desprende del propio artículo 1612 CC.

Considero que la primera postura es más acertada y conforme con el espíritu de la subrogación, que es un pago, al que viene primeramente obligado el deudor y por eso se protege su interés. La subrogación no es para el subrogado una operación especulativa, su ánimo no está en adquirir el crédito sino en pagar la deuda asegurándose el reembolso, por lo que la subrogación implica una garantía respecto de su crédito, a lo que cabe agregar que en el origen de la subrogación se encuentra la idea que el tercero ha actuado por

subrogación sin perjuicio del deudor y de terceros, acreedores anteriores o posteriores a esa subrogación convencional. En apoyo de su tesis cita la doctrina francesa, que hace una clara distinción entre la cesión y la subrogación, y los comentarios de Bibiloni al proyecto de reforma del CC. argentino.

${ }^{131}$ Alessandri R., Arturo - Somarriva U., Manuel - Vodanovic, Antonio, cit. (n. 12), p. 19, al hacer la distinción entre la subrogación y la acción de reembolso, señalan que esta es una de las diferencias. Sin embargo, en el volumen 3, p. 30, al hacer la diferencia entre subrogación y cesión, señalan que aquella no tiene fin de lucro.

${ }^{132}$ Díez-Picazo, Luis, cit. (n. 2), p. 1002, apoyado en el texto del artículo 1212 CCEsp.: "La subrogación transfiere al subrogado el crédito con los derechos a él anexos [...]".

${ }^{133}$ Véase más arriba, la nota 128. 
un oficio amistoso hacia el deudor. Distinto es el caso de la cesión, ya que en ella sí hay una operación especulativa propia de toda venta, como dice Claro Solar: "[...] el vendedor trata de vender lo más caro posible y el comprador procura pagar el menor precio" ${ }^{134}$.

Así se ha dispuesto para el caso del fiador que paga la deuda (artículo 2370 CC) y me parece que, no obstante el carácter de derecho estricto de la subrogación legal, es perfectamente posible una aplicación por analogía al codeudor solidario, ya que se trata de supuestos de pago de terceros interesados en la extinción de la obligación frente al acreedor.

Respecto de las excepciones admisibles en contra del solvens, el deudor podrá oponerle todas aquellas excepciones que hubiere podido oponer al acreedor hasta el pago, sea que emanen de la naturaleza misma de la obligación o sean suyas personales. La subrogación transfiere el crédito y todos sus derechos anexos, motivo por el cual se comprenden también todas las excepciones derivadas de la primitiva relación obligatoria. Nuestra jurisprudencia corrobora lo anterior y frente a un acreedor que ha pretendido hacer efectivo el monto total de la obligación sobre los bienes de los deudores solidarios no demandados en juicio, ha dicho que “...la solidaridad, por sí misma, no puede privar a los demás deudores del derecho de hacer valer las excepciones que resulten ... de la naturaleza de la obligación y también las personales que puedan tener contra el acreedor, en conformidad a lo dispuesto por el artículo 1520 CC." 135 . Luego, tratándose del mismo crédito, los codeudores que no han pagado conservan sus excepciones frente al nuevo acreedor.

Incluso, si el codeudor que paga no notifica el pago al resto de sus codeudores, podrán estos oponerle todas las excepciones válidas que hubieren tenido en contra del acreedor hasta dicha notificación.

Lo mismo que ya dijimos en el párrafo anterior, sí se ha dispuesto respecto del fiador que paga la deuda y no lo comunica al deudor: queda expuesto a desconocer las excepciones inherentes a la deuda que habría podido oponer el deudor al acreedor y por ello es justo que sufra su propia negligencia ${ }^{136}$.

Respecto de la compensación, podrán los codeudores oponer al solvens todos los créditos adquiridos contra el acreedor antes del pago. Si el codeudor tenía una excepción válida frente al acreedor, de haber tenido noticia del pago habría podido oponer la excepción impugnando el derecho del acreedor.

En el fondo, strictu sensu, no se trata aquí del pago de un tercero, el codeudor solidario viene obligado en forma principal a la deuda, lo mismo que el fiador, aunque que éste sujeto a la conditio iuris del impago; en este

\footnotetext{
${ }^{134}$ Claro Solar, Luis, cit. (n. 19), p. 222.

${ }^{135}$ Corte Suprema, 15 de septiembre de 2010, en FM. 554 (2010), pp. 149 y ss.

${ }^{136}$ Díez-Picazo, Luis, cit. (n. 2), p. 580.
} 
punto, quedan superadas las disquisiciones sobre responsabilidad sin deuda que se atribuían a la fianza ${ }^{137}$.

Ahora bien, podría plantearse que el solvens pague la deuda con aprobación del deudor y en virtud de las normas generales del pago sea titular, además, de una acción personal de reembolso surgida, ex novo, a raíz del pago efectuado. Ello ocurriría cuando el tercero actuase en virtud de un mandato conferido por sus codeudores, por lo que se encontraría en disposición de ejercer la acción de reembolso en contra de los codeudores ${ }^{138}$. ¿Surge para él la opción frente a las dos acciones o queda regido únicamente por la situación de subrogación legal? Y si se estima que surge la opción, ¿en qué momento debe efectuarla?

Para algunos autores el solvens debe optar, al momento del pago, por una u otra vía, de modo que, si decide subrogarse no nace el derecho personal de reembolso, posición más extrema ${ }^{139}$, o que si opta por subrogarse se produciría una cierta unificación de acciones ${ }^{140}$. No comparto lo anterior, estimo que ello implica confundir la legitimación para pagar del tercero con los efectos, no es que este tercero tenga doble legitimación sino que su legitimación es una pero se producen dos efectos. La subrogación debe entenderse siempre como

${ }^{137}$ Véase Giorgianni, Michele, cit. (n. 3), p. 169; Díez-Picazo, Luis, cit. (n. 2), pp. 99-101, para quien el fiador es deudor, no de la obligación principal garantizada, sino de su propia obligación y cuando paga cumple su propia deuda; y Feliú ReY, Manuel Ignacio, Fianza real, subrogación por pago de tercero interesado y solidaridad no uniforme, en La Ley, 7 (Madrid, 2001), pp. 1482-1490.

${ }^{138}$ Peñailillo Arévalo, Daniel, cit. (n. 120), p. 296, observa que también puede surgir la acción de mandato si se tiene en cuenta la doctrina del mandato tácito y recíproco sobre la naturaleza jurídica de la solidaridad pasiva.

${ }^{139}$ Hernández Moreno, Alfonso, cit. (n. 30), pp. 228 y 229. Aunque en realidad esta postura refleja una cierta confusión entre la legitimación para el pago y los efectos de ese pago y ello obedece a su particular visión sobre el pago de tercero y la subrogación, que descansa sobre la base de distinguir dos legitimaciones diversas: la del tercero extraño, que siempre paga extinguiendo la deuda y la del tercero interesado, que puede elegir con que legitimación pagar. Así, haciendo valer su especial legitimación - por el interés que posee- su pago nunca es extintivo y nunca nacerá para él la "opción" de acciones. A tal punto llega, que si posteriormente renuncia a la subrogación, no tendrá acción alguna contra el deudor. También adhieren a la exigencia de optar al momento del pago Bercovitz y Rodríguez Cano, Rodrigo - Valladares Rascón, Etelvina, en Albaladejo, Manuel - Díaz Alabart, Silvia (coordinadores), Comentarios al Código Civil y Compilaciones Forales (2a edición, Madrid, Edersa, 1991), XVI, $1^{\circ}, \mathrm{p}$. 50 , aunque por otras razones, señalan que de producirse la subrogación no puede nacer la acción de reembolso pues el crédito, la obligación, no se ha extinguido. Cfr.

${ }^{140}$ Es lo que plantea para el caso del fiador Reyes López, María José, Algunas consideraciones sobre los artículos 1.838 y 1.839 del Código civil, en Anuario de Derecho Civil, 41 (1988) 1, pp. 211-212 y 220. 
un beneficio para el solvens y por eso se produce la adquisición adicional del crédito pagado ${ }^{141}$. Ahora, nada obsta que el tercero manifieste al momento del pago que no desea subrogarse. En lo demás, su voluntad sólo será decisiva para optar por uno de los dos derechos, al momento de su ejercicio.

En caso que el tercero fuese titular, además, de una acción cambiaria de reembolso, emanada de la letra de cambio o del pagaré, podría convenirle más ejercer la acción adquirida por subrogación, derivada del negocio causal, atendidos los breves plazos de prescripción de dichas acciones ${ }^{142}$. Nuestra jurisprudencia ha reconocido la independencia de ambas acciones, cambiaria y derivada del negocio causal, permitiendo el ejercicio de la segunda cuando se encuentre prescrita la primera ${ }^{143}$. En todo caso, reconoce que al tercero, en su calidad de fiador y codeudor solidario le corresponden también la acción ordinaria de reembolso contemplada en el artículo 2370 CC y la acción por subrogación establecida en el artículo 1610 № 3 CC., para dirigirse en contra de los deudores principales o directos cuyas deudas han sido extinguidas "toda vez que se trata de acciones que no son incompatibles entre si y que son de libre elección para su titular" 144 .

La doctrina, sin embargo, se encuentra dividida; una parte de los autores considera que el solvens debe optar por una de las dos vías, ya que ambos créditos se excluyen recíprocamente, en palabras de Hernández-Gil: "la titularidad es cumulativa; no así su ejercicio, que es alternativo"145. Si bien la subrogación opera ex lege, automáticamente al tiempo del pago, puede el tercero renunciar a ella y optar por la acción de reembolso, lo que debería

${ }^{141}$ Así lo aclara Del Olmo García, Pedro, cit. (n. 73), p. 179. No obstante, para este autor el nacimiento de los dos derechos no se produce en pie de igualdad, el derecho personal es el principal ya que determina lo que el solvens debe recibir en definitiva; el adquirido por subrogación es accesorio, existe en función de garantía del derecho personal subyacente. Esta idea de que la subrogación existe en función de garantía hacia el tercero también se encuentra en FERNÁNDEZ Villa, José, cit. (n. 30), pp. 324-336, quien la caracteriza como una "medida de refuerzo del derecho de regreso".

${ }^{142} \mathrm{El}$ artículo 82 inciso $3^{\circ}$ de la Ley $\mathrm{N}^{\circ} 18.092$, establece que "El avalista que paga la letra tendrá acción cambiaria de reembolso en contra de la persona a quien él ha garantizado y de los demás firmantes de la letra respecto de los cuales tuviere acción cambiaria de reembolso la persona avalada" A su vez, el artículo 87 señala que: "Cualquier tercero extraño a la letra podrá pagarla y se subrogará en todos los derechos del portador emanados del documento [...]" El artículo 99 contempla el plazo de prescripción de seis meses desde el día del pago para las acciones de reembolso.

${ }^{143}$ Corte Suprema, 7 de mayo de 2001, en LegalPublishing No 18.705.

${ }^{144}$ Corte Suprema, 18 de junio de 2002, en LegalPublishing No 24.683. La Corte rechazó los recursos de casación en la forma y en el fondo deducidos contra la sentencia de segunda instancia que confirmó la de primer grado en la que se contiene el texto citado.

${ }^{145}$ Hernandz-Gil, Antonio, cit. (n. 3), p. 292. 
hacer en el mismo momento del pago ${ }^{146}$. Es obvio que impera aquí el principio de que no se da beneficio alguno a quien no lo quiere, por lo que el tercero podrá pagar como simple legitimado universal conforme al artículo $1572 \mathrm{CC}$. Otros autores consideran que se trata de derechos complementarios, en que la subrogación vendría a cumplir un efecto de garantía respecto de la acción de reembolso, sin perjuicio de accionar alternativamente ${ }^{147}$. En todo caso, de operar como garantía del reembolso quedan fuera de la garantía los intereses, si el crédito originario no los consideraba, los gastos y demás posibles perjuicios, que sólo podrán cobrarse ejercitando la acción de reembolso ${ }^{148}$. Para Díez-Picazo no se trata de concurso de normas ya que las pretensiones del demandante son diferentes, no sólo en cuanto a su fundamento sino en cuanto a la cuantía de lo pedido en uno y otro caso ${ }^{149}$.

Ahora bien, si el tercero que paga se encuentra al mismo tiempo bajo dos de los supuestos del artículo 1610, su causa de pedir será siempre la subrogación por pago, pudiendo invocar cualesquiera de los supuestos o ambos ${ }^{150}$.

A nuestro entender, a pesar que ambas acciones, la derivada de la subrogación como la de reembolso, responden a una misma ratio, cual es la de prevenir un enriquecimiento sin causa, e incluso ambas encuentran su origen en la ley, se trata de un supuesto de concurrencia de distintas acciones, cada una con presupuestos operativos propios y también, de efectos diversos. Además, como acertadamente advierte un autor, no parece "[...] plausible que la ley compela a emplear sólo una de las vías, de manera irreversible, con riesgo de que pudiera producirse lo que a toda costa intenta soslayar"151.

${ }^{146}$ Bercovitz y Rodríguez Cano, Rodrigo - Valladares Rascón, Etelvina, cit. (n. 139), p. 49. Pese a que el artículo 1210 CC. español utiliza la expresión: "se presumirá que hay subrogación [...]", estos autores entienden que se trata de subrogación legal, del mismo modo que en el Derecho chileno.

${ }^{147}$ Díez-Picazo, Luis, cit. (n. 2), p. 561; y Del Olmo García, Pedro, cit. (n. 73), pp. 297-330. La doctrina española también se haya dividida entre quienes consideran que la ley ha establecido una serie de derechos escalonados para proteger al solvens (Díez-Picazo) y los que estiman que cada derecho nace según su específico supuesto de hecho, en este sentido, quien tiene una acción de reembolso por ser mandatario no tendrá la de menor rango, de enriquecimiento, al mismo tiempo (Del Olmo).

${ }^{148}$ Alonso Sánchez, Beatriz, Protección del fiador en vía de regreso (Madrid, Tecnos, 1993), p. 32-33.

${ }^{149}$ Cfr. Díez-Picazo, Luis, cit. (n. 2), p. 561.

${ }^{150} \mathrm{Al}$ respecto se ha fallado que el hecho de invocar en la demanda la subrogación en virtud del No 5 del artículo 1610 CC. y en la réplica aducir la concurrencia del № 3 del mismo artículo, no implica variación en la causa de pedir ya que se mantiene el hecho material o jurídico que constituye la esencia de la acción, la subrogación por el pago. Véase sentencia de la Corte de Apelaciones de de Santiago, 24 de abril de 1990, en Legal Publishing No 10.994.

${ }^{151}$ Rubio Garrido, Tomás, cit. (n. 74), p. 143. 
ii) El deudor subsidiario. Se trata en este caso de un tercero ${ }^{152}$ que responde de la obligación en forma subsidiaria del deudor principal, es decir, cuando el deudor principal no cumple ${ }^{153}$. El caso paradigmático es el del fiador ${ }^{154}$, sin embargo existen otros muchos casos de deudores subsidiarios que también se subrogan por el pago, v. gr. el dueño de la obra o empresario en casos de subcontratación, otros derivados de las relaciones de familia, como la responsabilidad subsidiaria del hijo sometido a patria potestad (artículo 261 CC), la responsabilidad del legatario por las deudas hereditarias (artículos $1104 \mathrm{y}$ $1362 \mathrm{CC}$ ), de los varios tutores y curadores que administran separadamente (artículo 419 CC), la responsabilidad del socio por las deudas sociales, el que otorga una prenda para garantizar una deuda ajena, el tercero que se ha obligado en una cláusula penal ${ }^{155} \mathrm{o}$ el patrocinador de una carta de patrocinio o "comfort letter"156. Todos estos casos caben, sin duda, dentro del No 3 del

${ }^{152}$ Ya hemos dicho que es tercero en cuanto paga la deuda del deudor principal y extingue la obligación que este tiene con el acreedor, como señala Vial Del Río, Víctor, cit. (n. 8), p. 349, "está pagando una deuda ajena”.

${ }^{153}$ Cfr. Vodanovic H., Antonio, La fianza (2a edición, Santiago, LexisNexis, 2004), pp. 21-22, explica la diferencia entre la responsabilidad subsidiaria propia del fiador y el hecho que se le pueda considerar obligación condicional o eventual. Véase también Díez-Picazo, Luis, cit. (n. 2), p. 483, que explica la subsidiariedad como el orden necesario en la responsabilidad por la obligación, que debe ser cumplida una sola vez.

${ }^{154}$ Por esta razón utilizaré indistintamente "fiador" y "deudor subsidiario".

${ }^{155}$ En este caso, es necesario, para que se de la subrogación, que la pena se haya pactado como sustitutiva o indemnizatoria de la obligación principal y no como pena moratoria o punitiva. Para las diversas funciones de la cláusula penal (garantizadora del cumplimiento, resarcitoria de los perjuicios por incumplimiento, resarcitoria de la mora y punitiva), véase: CoRRAL TALCIANI, Hernán, Contratos y daños por incumplimiento. Estudios sobre su régimen jurídico y la responsabilidad por incumplimiento (Santiago, Abeledo Perrot - LegalPublishing, 2010), pp. 253-254. Véase también: Gatica Pacheco, Sergio, Aspectos de la indemnización de perjuicios por incumplimiento del contrato (Santiago, Editorial Jurídica de Chile, 1959), pp. 376-381. En contra: VIAL Del Río, Víctor, cit. (n. 8), pp. 349-351, quien manifiesta haber variado de opinión, respecto de la primera edición, y estima que el tercero que se obliga a una pena no puede subrogarse y tampoco adquiere derechos de reembolso ya que no cabría dentro del concepto de deudor subsidiario. En mi opinión, esta conclusión podría matizarse distinguiendo las funciones que puede cumplir la pena, en que, además de ser una avaluación convencional de perjuicios, ella posee un carácter esencial de garantía.

${ }^{156}$ Las cartas de patrocinio constituyen una garantía del tráfico usualmente utilizadas en la práctica bancaria y darán origen a responsabilidad subsidiaria del patrocinador cuando éste garantice o se comprometa para con un destinatario, acreedor de la obligación principal, a cumplir o indemnizar en caso de incumplimiento del patrocinado o deudor principal. En doctrina se les ha denominado "cartas de patrocinio fuertes" en oposición a las "débiles" que no importan una responsabilidad de este tipo. Para este 
artículo 1610 CC. e incluso en algunos casos la ley vuelve a mencionar el efecto subrogatorio del pago que dichos obligados realizan ${ }^{157}$.

Parte de la doctrina, al igual que en el caso anterior, considera que el fiador no es un tercero sino un verdadero deudor, que viene obligado al pago $^{158}$. Esta idea es correcta en parte, ya que el fiador es responsable por su propia obligación accesoria de garantía, pero al pagar salda una deuda ajena, que garantizaba y de allí su interés en la obligación, pues extinguida la obligación principal se extingue la accesoria de fianza (artículo 2381 CC.). Precisamente la especialidad de esta deuda subsidiaria radica en que cuando paga el fiador cumple su propia obligación de fianza, la obligación fideiusoria. Al pagar quedará satisfecho el interés perseguido por el acreedor en el derecho de crédito que poseía contra el deudor fiado, por lo que el deudor se liberará del acreedor, pero no quedará agotada la relación de fianza sino que ella proyectará algunos efectos aún, ahora entre el solvens y el deudor: la relación de regreso.

Hemos dicho que el fiador se encuentra sujeto al poder de agresión del acreedor, al menos en forma mediata, de allí su interés y por ello la ley lo legitima cualificadamente para el pago y le otorga la posibilidad de subrogarse legalmente, es decir, por el sólo hecho del pago y aún contra la voluntad de acreedor y deudor. Aún más, la ley protege la efectividad de este beneficio mediante una causal de extinción de la fianza cuando el acreedor por hechoo culpa suya ha perdido las acciones en que el fiador tenía derecho a subrogarse (artículo 2381 № 2 CC.) ${ }^{159}$.

A pesar de venir regulados en forma conjunta, existe una importante diferencia entre los dos supuestos de este $\mathrm{N}^{\circ} 3$, si bien ambos operan por el sólo ministerio de la ley, en el caso de los codeudores solidarios no basta, para conocer todos los efectos del pago, con aplicar el artículo 1610, sino que habrá de atenderse al negocio causal que originó la obligación pagada, por lo que necesariamente debe integrarse la norma del artículo $1522 \mathrm{CC}$. De este matiz que distingue ambos tipos de subrogación da cuenta una sentencia de la Corte Suprema, que dispuso: "[E]lfiador quepaga satisface una obligación

tema, véase AlCalde Silva, Jaime, Las cartas de patrocinio. Criterios dogmáticos para su aplicación en Chile (Santiago, Abeledo Perrot - LegalPublishing, 2010), especialmente pp. 17,34 y ss., y 65 .

${ }^{157}$ Por ejemplo, el artículo 64 bis CT. dispone en su inciso $4^{\circ}$ : "En todo caso, el dueño de la obra, empresa o faena, o el contratista en su caso, podrá pagar por subrogación al trabajador o institución previsional acreedora".

${ }^{158}$ Hernández-GiL, Antonio, cit. (n. 3), p. 209.

${ }^{159}$ Sobre este punto, puede verse la monografía de Alonso SÁnCHEZ, Beatriz, cit. (n. 148), que trata la situación en el derecho español, cuyo artículo 1852 CC. es muy similar al nuestro. 
integramente ajena y se subroga en los derechos del acreedor en contra del deudor principal por el total de lopagado. La subrogación a favor del codeudor solidario, en cambio, tiene lugar en los términos que señala el artículo 1522 del Código Civil y será, en definitiva, el interés de los codeudores en el negocio causal lo que determinará la pertinencia de dicha subrogación legal"160.

Si se pacta la solidaridad del fiador, éste vendrá obligado al pago junto al deudor principal pero, si paga, saldará una deuda totalmente ajena que garantizaba, en cambio el simple codeudor solidario al pagar saldará una deuda en parte ajena y en parte propia.

Si ha otorgado la fianza por mandato de un tercero, tendrá acción, además, en contra de su mandante (artículo 2371 CC.).

Si son varios los deudores afianzados, habrá que distinguir si eran o no solidarios. Si lo eran, podrá el fiador dirigirse en contra de cualesquiera de ellos por el total pagado. Si la fianza se prestó sólo respecto de uno de ellos, el fiador que pagó sólo contra éste podrá dirigirse por el total y su acción respecto de los demás será la que corresponda por haberse subrogado en los derechos del deudor a quien afianzó (artículo 2372 CC.).

Si son varios los fiadores, el fiador que pagó más de lo que correspondía a su cuota también se subroga, por el exceso, en los derechos del acreedor contra sus cofiadores (artículo 2378 CC.).

En el caso de la fianza real o hipotecaria, la ley dispone la subrogación del fiador en los términos del artículo 2429, respecto de la finca hipotecada. En cuanto a su responsabilidad personal, le serán aplicables las normas de la fianza, por lo que conserva su carácter de deudor subsidiario.

El fiador, al mismo tiempo que se subroga, goza de una acción personal de reembolso en contra del deudor, para obtener el reintegro de lo pagado, los intereses por el anticipo, los gastos del pago e incluso la indemnización de los perjuicios que haya podido sufrir luego de haber notificado al deudor la demanda del acreedor ${ }^{161}$. Como hemos visto, la opinión mayoritaria de los autores se inclina por afirmar que el fiador tiene un derecho de opción frente a estas dos acciones ${ }^{162}$ y así también se ha manifestado la jurisprudencia ${ }^{163}$.

${ }^{160}$ Corte Suprema, 9 de noviembre de 2009, en LegalPublishing No 42.883.

${ }^{161}$ Estas dos acciones componen la vía de regreso del fiador contra el deudor en los sistemas que, como el nuestro, siguieron al Code en la materia. Otros sistemas, como el alemán y el suizo optaron por establecer únicamente la subrogación legal. Véase $\$ 774$ BGB. y artículo 507 del Código Federal Suizo de Obligaciones.

${ }^{162}$ Alessandri R., Arturo - Somarriva U., Manuel - Vodanovic, Antonio, cit. (n. 12), p. 17; y DíEz-Picazo, Luis, cit. (n. 2), p.608.

${ }^{163}$ Véase supra n. 160. Este fallo contiene un importante considerando al efecto: "Duodécimo: [...] atendida la situación fáctica y jurídica esgrimida por el tercerista para justificar su pretensión ["subrogatoria], es dable colegir que a aquél le era posible ejercer la acción de reembolso derivada del pago del pagaré, la relativa al pago en general y la 
$\mathrm{Al}$ ejercer el fiador la acción derivada de la subrogación el importe a reclamar estará limitado por cuanto haya pagado al acreedor, la cuantía de ese crédito es lo que puede obtener por esta vía, con todas las garantías accesorias al mismo. Respecto de los otros conceptos que pueden incluirse en la relación de regreso entre deudor y solvens, ex artículo 2370 CC. (intereses, gastos y perjuicios), será necesario que el fiador ejerza su acción personal de reembolso pues dichas partidas no están cubiertas por la subrogación ya que el acreedor no ha tenido derecho a las mismas y por eso mal podrían haberse traspasado al fiador. En otras palabras, se trata de indemnizaciones que nacen ex novo a favor del fiador "a diferencia del contenido propio del derecho de reembolso, [...] el cual sí podrá ser ejercitado por el fiador a través del mecanismo instrumental de la subrogación, y que nace como consecuencia del pago efectuado por cuenta del deudor principal" ${ }^{164}$. Considero, atendido lo dicho, que puede afirmarse una situación de concurrencia y complementariedad entre la acción de reembolso y la derivada de la subrogación, pero sólo la elección del fiador develará si ha optado por la subrogación en función del regreso, ya que puede elegir no hacerlo.

El fiador que paga debe comunicar el pago al deudor, de lo contrario se expone a las excepciones que pueda éste oponerle; todas las que habría podido oponer válidamente al acreedor al tiempo del pago. Si el deudor ignorante del pago, pagare de nuevo la deuda, no tendrá el fiador derecho para repetir en su contra, debiendo dirigirse en contra del acreedor mediante la condictio indebiti (artículo 2377 CC.).

d) El heredero beneficiario que paga con su propio dinero las deudas de la herencia ${ }^{165}$. A pesar que más arriba dijimos que bajo la designación del heredero se entiende actuar al deudor mismo, ya que ha operado la transmisión de todos los derechos y obligaciones transmisibles del causante, cuando este heredero ha aceptado la herencia con beneficio de inventario su responsabilidad queda limitada al monto de lo recibido en herencia. No responderá, por tanto, como lo hace el heredero corriente, ultra vires, sino que el fin del beneficio es precisamente limitar esta responsabilidad y por ello se entiende que, a pesar de estar pagando una deuda de

derivada del pago del negocio causal del pagaré [...]".

${ }^{164}$ Alonso SÁnCHEz, Beatriz, cit. (n. 148), p. 31, cita la opinión mayoritaria de la doctrina española a favor de reconocer dos acciones diversas al fiador, pero agrega que la verdadera discrepancia doctrinal consiste en determinar cómo se ejercen o que función cumple una respecto de la otra. Para la autora sólo existe una única acción de regreso que la ley refuerza mediante la subrogación en función de garantía.

${ }^{165}$ Este caso es el último recogido en el artículo 1251 CCFr. y no se ha contemplado en el artículo 1210 CCEsp. Los autores españoles, sin embargo, lo incluyen como un caso de subrogación legal. Véase: BAyo Recuero, Nieves, cit. (n. 27), p. 136. 
la herencia y por ende, propia, al gozar del beneficio paga una deuda ajena; en este sentido, es un tercero frente a la sucesión deudora.

El heredero tendrá interés en pagar las deudas de la herencia para conocer con certeza cual es el caudal hereditario del que finalmente dispondrá y además, para evitar la ejecución precipitada de los bienes de la herencia por parte de los acreedores, por eso la ley ampara este interés cuando paga con dineros propios sin utilizar los fondos de la herencia. Como se aprecia, el pago del heredero beneficiario actuará también en interés de los acreedores hereditarios y testamentarios, que recibirán el pago de sus créditos y legados anticipadamente por el heredero; y del resto de los herederos, evitándoles, por una parte, la venta forzada e intempestiva de los bienes de la herencia, tal vez en condiciones que no sean las más favorables para la sucesión y por otra, los gastos de la ejecución.

Dos son los requisitos adicionales para este pago: que se haya concedido el beneficio de inventario y que el heredero pague con su propio dinero (es decir, antes de que los bienes de la sucesión se confundan con los suyos propios). Por esto mismo, se excluye el caso en que se hubiere otorgado el beneficio de separación, ya que de haberlo los acreedores serán pagados con los bienes de la herencia y no con los propios del heredero.

Si son varios los herederos beneficiarios la subrogación por el pago que realice uno de ellos será parcial y no por la totalidad del crédito ya que deberá descontar de la reclamación en vía de regreso su parte o cuota en las deudas de la herencia.

e) El que paga una deuda ajena, consintiéndolo expresa o tácitamente el deudor ${ }^{166}$. Este supuesto de subrogación no estaba contemplado en el "Proyecto de 1853" y es también una innovación respecto del Code, que sólo permite la subrogación de este tercero por la vía convencional. Sin embargo, aparece en términos similares en el Proyecto de Código Civil español de $1851^{167}$.

${ }^{166}$ Este supuesto no se halla contemplado en el Code como caso de subrogación legal. El artículo 1236, que regula por quien puede hacerse el pago, excluye expresamente la posibilidad de subrogación legal. No obstante, la doctrina francesa se encuentra dividida y una parte entiende que la exclusión de la subrogación afecta únicamente al tercero que paga sin autorizarlo el deudor. Véase: Demolombe, Jean Charles Florent, cit. (n. 22), pp. 50-53, que acepta la subrogación legal del tercero ajeno a la obligación y no interesado, tanto en materia mercantil, para el caso del pago por tercero de una letra de cambio, debido al precedente histórico de la Ordenanza de Comercio Terrestre, de 1673, como en materia civil. También: Pothier, Robert Joseph, cit. (n. 94), p. 348, pero sólo para el ámbito mercantil.

${ }^{167}$ El artículo 1117 del Proyecto establecía la subrogación legal a favor "2. ${ }^{\circ}$ Del tercero no interesado que pague, consintiéndolo expresa o tácitamente el deudor”. En igual sentido el artículo 1210 № 2 CCEsp. 
En este caso, a diferencia de los demás enunciados en el artículo 1610 CC., no aparece que se trate de un tercero con un interés propio, cualificado, para efectuar el pago y sin embargo, se subroga de pleno derecho. Se trata, por tanto, de un tercero extraño o absoluto ${ }^{168}$. A falta de un interés jurídicamente relevante del tercero la ley ha exigido la voluntad del deudor favorable a su intervención y por ello da por establecido que el deudor al consentir el pago acepta el reemplazo del acreedor por el tercero que paga. Su consentimiento es prueba del interés.

Este tercero es, por lo mismo, un mandatario del deudor y por ello cuenta, además con la acción de reembolso que le otorga el artículo 2158 No 4 CC. Existen, sin embargo, autores que no reconducen la situación al contrato de mandato, sino a una autorización atípica distinta del mandato, por la que el deudor lo que consiente no es el pago, sino específicamente la subrogación ${ }^{169}$.

Estimo, con la mayoría de los autores, que la aprobación del deudor no es negocial en orden a la subrogación, el efecto subrogatorio no se sigue porque haya sido querido por el deudor, sino que deriva directamente de la ley. La razón me parece de toda lógica si se tiene en cuenta que el deudor nada ha podido disponer respecto de un crédito que le es ajeno. Esta idea muy bien la expresa el autor español Rubio Garrido, citando a Sancho Rebullida, al decir que "si el deudor ha aprobado conscientemente la intervención del tercero, ya sea de modo tácito, ya expreso, por mucho que luego negase la subrogación, no podría ésta evitarse, pues no deriva de su voluntad negocial, sino directamente de la ley" ${ }^{170}$.

Se ha discutido si el pago con conocimiento del deudor puede quedar subsumido en este caso de subrogación. La opinión unánime de los autores considera que para dilucidar la situación es necesario apreciar las circunstancias que rodean al conocimiento, de modo que el conocimiento del deudor podrá asimilarse a su consentimiento tácito cuando la actitud y conducta del

${ }^{168}$ Abeliuk Manasevich, René, cit. (n. 7), p. 548, sostiene que no se trata de un tercero extraño porque el solvens es un mandatario para el pago, con lo que fija su atención en la existencia de una relación subyacente entre deudor y solvens, sin embargo, el criterio utilizado para definir al tercero interesado mira a la sujeción del tercero frente al poder de agresión del acreedor o a la incidencia que el pago revista en la consolidación de su derecho real y de allí que tenga interés en el cumplimiento de la obligación.

${ }^{169}$ Cfr. Hernández Moreno, Alfonso, cit. (n. 30), pp. 205-212, básicamente fundado en la incompatibilidad de intereses, entre pagador y deudor, que devela la subrogación al no extinguir la deuda. Esta incompatibilidad se sustenta en un interés propio del solvens y sería ajena al contrato de mandato. Sin embargo, se le puede criticar que el mandato puede perseguir también el interés del mandatario.

${ }^{170}$ Rubio Garrido, Tomás, cit. (n. 74), p. 194. 
deudor así lo supongan ${ }^{171}$. En todo caso, la Corte Suprema ha considerado que apreciar cuando hay consentimiento tácito del deudor es cuestión de hecho que deben resolver soberanamente los jueces del fondo ${ }^{172}$. Por otra parte, cuando no resulte acreditado que el solvens pagó con el consentimiento expreso o tácito del deudor, le quedará a salvo la acción de reembolso que contempla el artículo $1573 \mathrm{CC} .{ }^{173}$, por lo que estimo que siempre podrá el tercero interponerla en forma subsidiaria de la subrogación.

En cuanto al tiempo en que debe prestar su consentimiento el deudor, no hay duda que puede hacerlo antes del pago, lo que generalmente ocurrirá en el acuerdo negocial que pueda haber celebrado con el solvens y también puede hacerlo en forma coetánea al pago. La interrogante se presenta frente a la aprobación prestada a posteriori. En general, la doctrina estima que el pago efectuado sin la aprobación del deudor extingue inexorablemente la relación obligatoria, sin que pueda luego revivir ${ }^{174}$. Sin embargo, algún autor ha estimado que lo literal de la norma sólo se refiere a la hipótesis más frecuente pero nada impide que la aprobación se de después del pago ${ }^{175}$. Me parece que, atendido el carácter excepcional de la subrogación como efecto del pago, ella exige una interpretación estricta y lo más acorde con su regulación es el consentimiento prestado antes o al momento del pago. En esta línea, por lo demás, regula el Código la subrogación convencional. El artículo 1611 CC. exige que la subrogación se haga en la carta de pago; en este caso, mal podría hacerse antes ya que la propia figura supone un pago, pero bien podría hacerse después si la ley no hubiese dispuesto lo contrario y si así dispuso fue precisamente por estimar que el pago realizado extinguía definitivamente el crédito en poder del acreedor ${ }^{176}$.

La cuantía a reclamar queda fijada en la cantidad desembolsada por el solvens, como ya hemos visto en los casos anteriores. No es, sin embargo, una opinión unánime; para algunos autores la subrogación, sin ser una operación especulativa tampoco es una manifestación del favor debitoris, y por eso se

\footnotetext{
${ }^{171}$ Sobre esto volveré más adelante al tratar el pago del tercero con consentimiento del deudor.

${ }^{172}$ Corte Suprema, 28 de septiembre de 1908, en Revista de Derecho y Jurisprudencia, 6 (1908), $2^{\circ}$ parte, secc. $1^{\text {a }}$, p. 58; y Corte Suprema, 16 de junio de 1916, en Revista de Derecho y Jurisprudencia, 14 (1917), $2^{\circ}$ parte, secc. $2^{\mathrm{a}}$, p. 22.

${ }^{173}$ Corte de Apelaciones de Valparaíso, 27 de enero de 2003, en LegalPublishing No 28.549. En este caso se estimó que la circunstancia de encontrarse en poder del tercero los recibos de pago permitía acreditar el pago más no que dicho pago haya sido efectuado con el consentimiento expreso o tácito del deudor.

${ }^{174}$ Cfr. Fernández Villa, José, cit. (n. 30), pp. 384-385.

${ }^{175}$ Cfr. Rubio Garrido, Tomás, cit. (n. 74), p. 196.

${ }^{176}$ Véase Abeliuk Manasevich, René, cit. (n. 7), p. 612.
} 
traspasa el mismo crédito que el acreedor poseía, incluido su valor nominal, aunque el pago haya sido inferior ${ }^{177}$.

Las excepciones que puede oponer el deudor al solvens son todas aquellas derivadas de su relación con el acreedor originario hasta el momento del pago, es decir, todas aquellas propias del crédito satisfecho. En efecto, el crédito del nuevo acreedor ostenta los privilegios que ostentaba el antiguo y, de la misma manera, le perjudicarán las excepciones provenientes del crédito antiguo ${ }^{178}$. Para algunos también son oponibles las excepciones personales del deudor, incluidas las que habrían podido oponerse al acreedor originario ${ }^{179}$. Algún autor hace la distinción respecto de aquellas defensas que eran conocidas por el solvens o eran aparentes, caso en el que el deudor podrá oponerlas al nuevo acreedor y aquellas que no constaban pero que el deudor conocía, que no podrá oponer al nuevo acreedor ya que al aprobar el proyecto de pago por parte del tercero se entiende que renuncia a ellas ${ }^{180}$. Así, por lo demás, lo exigiría la buena fe y la equidad.

f) El que ha prestado dinero al deudor para el pago. La figura, conocida en doctrina como subrogación ex mutuo, no estaba presente en el "Proyecto de 1853", pero sí en los proyectos de 1842 y 1847, siendo introducida, en definitiva, por la Comisión Revisora. Los primeros proyectos, sin embargo, la tomaron de forma idéntica a como se contemplaba en el Code, como un caso de subrogación convencional hecha por el deudor, pero finalmente, considerando su similitud con el supuesto recién visto, del No 5 , se le dio el mismo carácter de subrogación por el sólo ministerio de la ley ${ }^{181}$.

En efecto, el caso es análogo al del artículo 1610 No 5 CC, pues allí se trata del que paga con su propio dinero una deuda ajena, consintiéndolo el deudor y aquí, es el deudor quien paga con el dinero ajeno una deuda propia. Como en ambos casos se prescinde de la voluntad del acreedor, la ley, entonces, le da carácter legal a la subrogación ya que mal podría hacerla el deudor que no es dueño del crédito.

Para que la subrogación opere, en este supuesto, se requieren ciertas formalidades, por lo que ha sido catalogada como un caso de subrogación legal

${ }^{177}$ Bercovitz y Rodríguez Cano, Rodrigo - Valladares Rascón, Etelvina, cit. (n. 139), p. 51. En contra Albiez Dohrmann, Klaus Jochen, cit. (n. 18), p. 88; y Alessandri R., Arturo - Somarriva U., Manuel - Vodanovic, Antonio, cit. (n. 12), p. 19.

${ }^{178}$ Cañizares Laso, Ana, cit. (n. 45), pp. 54 y 131 ss.

${ }^{179}$ Bondía Román, Fernando, La subrogación en el crédito, en Estudios de Derecho civil en homenaje al profesor Dr. José Luis Lacruz Berdejo (Zaragoza, J.M. Bosch, 1993), II, pp. 1013-1014.

${ }^{180}$ Serra Callejo, Javier, cit. (n. 82), p. 1103.

${ }^{181} \mathrm{Su}$ origen, en todo caso, se encuentra en el edicto de Enrique IV, de 1609, que consideró por vez primera la subrogación ex mutuo y al que ya nos hemos referido. 
solemne. Es necesario, entonces, que el tercero facilite dinero al deudor, con lo que es aplicable sólo al cumplimiento de obligaciones pecuniarias o que se han transformado en pecuniarias; el pago debe efectuarse con esos dineros y ambos hechos deben constar por escritura pública, la que puede ser una misma. Concurriendo estos requisitos se opera la subrogación por el ministerio de la ley y se cumple la finalidad para la que fue prevista: propender al cumplimiento de las obligaciones mediante el auxilio de un tercero que se beneficia al aprovecharle las seguridades y garantías del primitivo crédito ${ }^{182}$.

Aquí, como en los demás casos, también concurre un derecho personal de reembolso para el prestatario, que corresponde a la acción derivada del mutuo. Mediante el ejercicio de la acción derivada de la subrogación el tercero sólo podrá reclamar el interés que devengaba el crédito pagado, en cambio, optando por la acción derivada del mutuo podrá reclamar el interés pactado con el deudor.

\section{Supuestos Del PAgo DE Un TERCERo, 3: PAGO DE UN TERCERO SIN SUBROGACIÓN}

Dijimos antes, que para determinar los distintos supuestos de pago de tercero, que a su vez, originan diversos efectos, la ley ha atendido a la voluntad o posición del deudor respecto del proyecto de pago del tercero y a la existencia o no de un interés propio jurídicamente relevante del solvens. De esta manera, en presencia de ese interés, el pago que realiza el tercero no despliega sus efectos normales ya que sólo extingue la deuda frente al acreedor y no se libera al deudor, que queda obligado en iguales términos frente al solvens por efecto de la subrogación. Corresponde ahora, fijarnos en el pago de un tercero no interesado especialmente en la obligación o en su cumplimiento, que será un pago de efectos normales y que cumplirá a cabalidad las tres funciones distintivas que lo caracterizan, satisfactiva, extintiva y liberadora. Cabe precisar, con todo, que al decir "un tercero no interesado" sólo pretendo descartar un interés jurídico especialmente relevante, como puede ser el de evitarse una agresión patrimonial del acreedor, ya que es evidente que el tercero al pagar tendrá algún interés o motivación personal, sólo que la ley no lo ha estimado suficiente como para reforzar la legitimación y conceder la subrogación y ello básicamente porque el interés del tercero, en estos casos, se identificará con el interés del deudor de extinguir la obligación.

a) Pago con conocimiento y aprobación del deudor. Esta situa-

${ }^{182}$ Cfr. Ledermann Rodríguez, Ricardo, De la subrogación legal en beneficio del que habiendo comprado un inmueble, es obligado a pagar a los acreedores a quienes el inmueble está hipotecado, en Revista de Derecho y Jurisprudencia, 26 (1929), Derecho, p. 140. 
ción surge cuando paga el tercero con conocimiento y aprobación, expresa o tácita del deudor. Así se deduce de la interpretación a contrario del artículo 1574 CC. Dispone la citada norma que el que paga contra la voluntad del deudor no tiene derecho para que el deudor le reembolse lo pagado, de donde puede deducirse que si paga con el asentimiento del deudor tendrá derecho al reembolso. Es claro que lo que viene exigido al caso es más que el simple conocimiento del pago por parte del deudor, debe además, aprobarlo.

La concordancia con el artículo $1610 \mathrm{~N}^{\circ} 5 \mathrm{CC}$, en cuya virtud el tercero que paga consintiéndolo expresa o tácitamente el deudor se subroga en los derechos del acreedor, permite interpretar correctamente la norma del artículo $1573 \mathrm{CC}$, ya que el que paga sin conocimiento del deudor no se subroga y tampoco, a contrario sensu, se subroga quien paga con conocimiento del deudor pero sin su aprobación expresa o tácita. De modo que, de no existir el No 5 del artículo 1610, podría haberse generado la duda de si se subroga o no el que paga con el sólo conocimiento del deudor. La situación entonces, queda regida por el artículo 1574 interpretado a contrario sensu y no por el 1573 CC.

La doctrina es unánime en considerar que el conocimiento del deudor no seguido de una prohibición expresa constituye aprobación tácita. Lo que sí parece prudente es que entre el conocimiento del proyecto de pago del tercero y el pago mismo haya transcurrido un término razonable, en que el deudor haya podido oponerse eficazmente. El fundamento de esta exigencia se haya en la buena fe exigible al deudor, quien conociendo la intención de pagar del tercero, está obligado a manifestarle su negativa, de modo que si no lo hace es de presumir que aprueba el pago. Del artículo 1610 No 5 CC. se puede fácilmente colegir que la aprobación, en este caso, puede ser expresa o tácita, ya que siendo así para los casos de subrogación, con mayor razón lo será en términos generales y también del artículo 2123, que permite que el encargo en que consiste el mandato pueda hacerse aún mediante la aquiescencia tácita de una persona a la gestión de sus negocios por otra.

El tercero que ha pagado con el consentimiento del deudor es verdaderamente un mandatario del mismo, por esta razón, la acción de reembolso de que dispone es la acción derivada del mandato ${ }^{183}$. El solvens podrá repetir no sólo lo pagado, sino también los gastos, intereses e indemnizaciones por pérdidas sufridas, sin su culpa, con ocasión del pago (artículo $2158 \mathrm{~N}^{\circ} \mathrm{s} 2,4$ y 5 CC). En contra de esta idea, algunos autores consideran que la cuantía a perseguir mediante la acción de reembolso no podría ser superior a la

${ }^{183}$ Por todos, Ramos Pazos, René, cit. (n. 24), p. 348. 
cantidad pagada por el solvens al acreedor, independientemente del valor nominal del crédito $^{184}$.

¿Qué sucede si el acreedor aceptó un pago menor, condonando el resto? ¿Aprovecha al deudor? Me inclino por la afirmativa, primeramente porque el artículo 2147 CC, prohíbe expresamente al mandatario apropiarse de lo que exceda al beneficio o minore el gravamen designado en el mandato. Esta norma resume el espíritu que debe impregnar la relación entre solvens y deudor, ya que el tercero pagador ha actuado, no con un fin de lucro personal o especulativo, sino en orden a gestionar el negocio ajeno de la mejor manera para su mandante, lo mismo en el caso del agente oficioso. Sin perjuicio de ello, no cabe duda que se encuentra habilitado para demandar el cobro de las expensas originadas en el pago, los intereses y la indemnización que procediere por pérdidas sufridas sin su culpa con ocasión del pago.

Respecto a las defensas y excepciones que puede hacer valer el deudor en contra del solvens, éstas deben tener su origen en hechos posteriores al pago ya que la acción de reembolso surge, ex novo, inmediatamente después de efectuarse el pago. En principio, quedarían fuera, por ser totalmente ajenas a este nuevo crédito, las excepciones que pudieran oponerse al crédito pagado.

De este modo, no podría el deudor oponerle la prescripción de la deuda pagada cumplida en un tiempo posterior al pago; la prescripción, en este caso, debe predicarse respecto de la acción de reembolso y el tiempo necesario para que ello ocurra será el ordinario de cinco años, contado desde la fecha del pago (artículos 2514 y 2515 CC), sin perjuicio de la prescripción de corto tiempo que pudiere afectar a la acción de cobro de la remuneración del mandato (artículo $2521 \mathrm{CC}$ ).

Pienso, sin embargo, que la respuesta se puede matizar y para ello resulta útil considerar que el solvens ha debido emplear en el cumplimiento del encargo la diligencia del buen padre de familia, por ello parece justo que pueda reclamar en vía de regreso todo aquello que pagó sin mediar culpa de su parte. Si el tercero pagó con abuso de confianza o más de lo que debía el deudor, por su propia culpa, éste podrá oponerle excepciones derivadas del crédito originario, destinadas a demostrar que era menor la cantidad debida y que habría opuesto al acreedor mismo de ser él el que hubiere realizado el pago. Quedarían así, por la vía del examen de la diligencia del solvens, admitidas las excepciones del crédito pagado que hubiera podido oponer el deudor a su acreedor antes del pago del tercero. Con todo, cabe recordar que se trata

${ }^{184}$ Serra Callejo, Javier, cit. (n. 82), p. 1086; y Albiez Dohrmann, Klaus Jochen, cit. (n. 18), p. 82, ya hemos dicho que parte de la doctrina no reconduce necesariamente el pago del tercero a las relaciones de mandato o agencia que pudieran existir entre deudor y solvens, con lo que la consecuencia es una acción de reembolso restringida. 
de un pago autorizado por el deudor, por lo que su oposición en sede de regreso se encuentra sumamente limitada, pudiendo recurrirse fácilmente a la doctrina de los actos propios.

$\mathrm{Al}$ mismo tiempo, la ley otorga a este tercero la facultad de subrogarse en los derechos del acreedor (artículo 1610 No 5). La jurisprudencia ha sido clara al respecto, de modo que, acreditado el pago, se produce la subrogación por el sólo ministerio de la ley ${ }^{185}$.

Existen, no obstante, autores que no identifican los supuestos de hecho de la subrogación legal con el pago de tercero consentido por el deudor. Las situaciones de hecho podrían ser distintas según el pacto o acuerdo entre solvens y deudor, de modo que sólo se produciría la subrogación legal si el deudor consiente en ella al aprobar el pago, excluyendo el derecho de reembolso. A la inversa, podrían haber acordado que no habrá lugar a la subrogación. También podría darse la situación de haber manifestado el solvens una intención de liberalidad para con el deudor, caso en el cual nada podría repetir en su contra ${ }^{186}$.

Me parece que lo anterior no es válido en nuestro derecho, donde existe norma expresa en orden a que la subrogación opera, en estos casos, por el sólo ministerio de la ley, independientemente de la voluntad del acreedor (aun contra su voluntad) y del deudor, cuya voluntad sólo importa a efectos de haber consentido el pago pero carece de poder para determinar si se producirá o no el efecto subrogatorio. Sobre todo debe tenerse en cuenta que la subrogación no es ni un hecho ni un acto jurídico dispositivo, es un efecto jurídico automático ${ }^{187}$. Por esta misma razón, la aprobación del deudor al pago debe realizarse antes o en el momento del pago, de ser posterior se impide el efecto subrogatorio ya que la obligación se ha extinguido. De tal modo que, si el deudor ratifica el pago después de efectuado, el solvens sólo contará con la acción de reembolso.

En este caso, entonces, el solvens dispondrá de dos acciones diversas para el reembolso de lo pagado, debiendo optar por una de ellas, lo que hará tomando en consideración las ventajas que cada una pueda representarle en el caso concreto. En virtud de la acción de mandato es posible reclamar no sólo el importe de lo pagado sino también intereses corrientes en caso de haber pagado con fondos propios anticipados al deudor mandante y los gastos razonables que le haya irrogado el pago, así como toda pérdida no culpable en que haya incurrido con ocasión del pago. Podrá, asimismo, obviar las excepciones inherentes al crédito pagado. Si opta, en cambio, por subrogarse

\footnotetext{
${ }^{185}$ Corte Suprema, 23 de octubre de 2003, en LegalPublishing № 28.689.

${ }^{186}$ Serra Callejo, Javier, cit. (n. 82), p. 1096.

${ }^{187}$ Cfr. Lacruz Berdejo, José Luis, Elementos de Derecho civil ( $3^{a}$ edición, Barce-
} lona, Bosch, 1994), II, $1^{\circ}$, p. 232. 
en los derechos del acreedor, gozará del crédito por su valor nominal, en los mismos términos que aquél, con todos sus accesorios (derechos, acciones, privilegios, prendas e hipotecas), por lo que esta vía podría resultarle más estrecha que la actio mandati contraria pero, sin embargo, más efectiva ya que en el primer caso sólo contará, como garantía, con el derecho de retención que le otorga el artículo 2162 CC, que no posee carácter real ni otorga preferencia alguna.

¿En qué momento debe el solvens optar por una u otra vía? Podría exigirse la opción al momento del pago o bien al tiempo de interponer la respectiva demanda. Estimo que el artículo 1610, al regular los casos de subrogación legal, no ha tenido en consideración la voluntad del solvens en orden a querer subrogarse, sino más bien se trata de una situación objetiva, cumplidos los requisitos que en cada caso se exigen, la subrogación opera por el sólo ministerio de la ley, por este motivo me parece acertado sostener que la opción la hará el solvens al intentar una u otra vía de regreso, pudiendo incluso interponer ambas acciones, una en subsidio de la otra. Con todo, cabe advertir que, habiéndose inclinado por una de las acciones, será el régimen de dicha acción la que regirá todo el proceso restitutorio, de modo que optando por la subrogación sólo cabría cobrar los gastos e intereses por la vía de la actio mandati contraria, y no quedarían cubiertos por las garantías del crédito en que se subrogó el solvens.

b) Pago de tercero en la ignorancia del deudor. Se trata de un tercero que, actuando a nombre propio paga por cuenta del deudor en la ignorancia de éste. En este caso se concede al solvens derecho a obtener el reembolso de lo pagado. Así lo dispone el artículo 1573 CC., señalando expresamente que no se producirá la subrogación legal en el lugar del acreedor y que tampoco podrá el tercero compeler al acreedor a que lo subrogue.

Esta situación alude a un tercero sin interés personal en el pago de la deuda, de tenerlo quedaría recogido en alguno de los casos contemplados en el artículo 1610, operando a su respecto la subrogación legal, que para nada considera la voluntad del deudor. Nada obsta, sin embargo, para que el acreedor pueda libremente subrogar convencionalmente al tercero en sus derechos, siendo irrelevante el conocimiento o la aprobación del deudor. En este caso, la subrogación queda sujeta a la regla de la cesión de derechos, por lo que la voluntad o conocimiento del deudor operan después de la subrogación y no como requisito previo. La subrogación se hará, en estos casos, en la carta de pago (artículo $1611 \mathrm{CC}$ ). Al decir nuestro Código que la subrogación operada en estos casos se rige por la regla de la cesión de derechos se despejan varias dudas propias de otros derechos, como en el caso español, en que ha sido la doctrina mayoritaria la que ha considerado que ambas situaciones se 
asemejan y rigen por las mismas normas, a pesar que existe algún autor que duda que la subrogación sea posible si el deudor se opone a ella ${ }^{188}$.

El supuesto de hecho en esta situación, según la doctrina, corresponde a la gestión de negocios ajenos, el tercero, sin conocimiento ni instrucciones del deudor realiza el pago a fin de extinguir la obligación ${ }^{189}$. Si bien la gestión de negocios, en general, corresponde a una labor de cierta continuidad en el tiempo y comprende una multitud de actos, no sólo encaminados a la extinción de las obligaciones ajenas, es claro que el cumplimiento de obligaciones ajenas sin mandato queda incluido en lo que se conoce como agencia oficiosa. Nuestra jurisprudencia, por lo demás, reconoce esta amplitud de objeto en la gestión de negocios y al efecto ha señalado que "[...] hay agencia oficiosa, pues, siempre que por evitar un daño, por servir a una persona o por un motivo análogo, de aquellos que imponen la necesidad de una acción, alguien toma a su cargo lo que el dueño, tal vez ausente o impedido, haria o debiera hacer si lo pudiera, en presencia de las circunstancias" ${ }^{190}$. El vencimiento de una obligación es, ciertamente, respecto del deudor, un motivo que impone la necesidad de una acción: el pago o cumplimiento de la misma.

Si miramos al interés que hay detrás de esta gestión encontraremos que se trata de un interés ajeno, que corresponde al deudor o dueño del negocio y al pagar el tercero y obtener el efecto normal del pago, cual es la liberación del deudor, tenemos que ha gestionado el interés del deudor que es verse

${ }^{188}$ Albaladejo García, Manuel, Derecho Civil (9a edición, Barcelona, Bosch, 1994), II, $1^{\circ}$, p.149. Cabe señalar que el artículo 1210 CCEsp. contempla la subrogación por pago de tercero no como casos de subrogación legal sino como situaciones en las que se presumirá que existe subrogación, lo que ha dado pie a la consiguiente discusión doctrinal acerca del carácter de esta presunción: presunción iuris tantum de subrogación o independientemente de la terminología utilizada en el Código, estimar que se trata de casos de subrogación legal. En relación con la doctrina nacional es preciso señalar que alguna discusión existe aún entre nuestros autores, en orden a determinar cuál es la regla de la cesión de derechos aplicable o si son todas las reglas aplicables; la posición mayoritaria se inclina por considerar que la regla se refiere a cómo se perfecciona la cesión entre el cedente y el cesionario y frente al deudor y terceros (ex artículos 1901 y 1902 CC.); cfr. Vial Del Río, Víctor, cit. (n. 8), p. 357. Claro Solar, Luis, cit. (n. 19), pp. 268 y 269, en cambio, sostiene que la regla de la cesión aplicable es sólo la del artículo 1902, que dispone notificar al deudor.

${ }^{189}$ Por todos, Abeliuk Manasevich, René, cit. (n. 7), p. 549; y Beltrán de Heredia y Castaño, José, cit. (n. 14), p. 139. En contra: Albiez Dohrmann, Klaus Jochen, cit. (n. 18), pp. 51-53, para quien cada figura tiene su propio ámbito de aplicación, siendo muchísimo más amplio el de la gestión de negocios ajenos, sobretodo por la asunción de deberes específicos por parte del gestor, que exceden lo que es un pago por tercero, de modo que si el tercero únicamente pretende liberar al deudor sólo debiera regirse por el artículo 1158 CCEsp., que le otorga la acción de reembolso.

${ }^{190}$ Corte Suprema, 26 de agosto de 2008, en FM., 550 (2008), pp. 169 ss. 
liberado de la obligación. Si bien el interés del solvens, en este caso, podría ser inferior al interés del deudor, no podría superarlo (como si quisiese adquirir el crédito por subrogación), de modo que su legitimación no alcanzará nunca a producir el efecto subrogatorio en el pago que realice y extinguirá siempre la obligación.

La acción de reembolso, en este caso, es la derivada de la gestión de negocios ajenos (actio negotiorum gestorum contraria), de manera tal que si el pago ha extinguido la deuda puede decirse que la gestión habrá sido bien administrada y por ello el agente tendrá derecho a que se le reembolsen las expensas útiles o necesarias. Dentro de estas expensas no sólo cabe el importe de lo pagado sino también los gastos que haya originado el pago y que de todos modos hubiere correspondido hacer al propio deudor de haber pagado él mismo ${ }^{191}$. Carece el gestor, en estos casos, de toda garantía para asegurarse el reintegro ya que a diferencia de la acción de reembolso del solvens mandatario, no posee derecho de retención.

Con relación a las excepciones que puede oponer el deudor al tercero, caben las mismas anotaciones hechas al pago efectuado con conocimiento y aprobación del deudor en cuanto el gestor debe la diligencia del buen padre de familia, al igual que el mandatario. No podría la ley proteger a un solvens torpe que se precipita y sin consultar con el deudor realizara un pago inútil para éste, otorgándole una acción de regreso inmune a las excepciones del deudor. Me parece que sería una situación sumamente injusta para el deudor. Algún autor estima, además, que si la ley concediese al tercero una acción inmune a las excepciones del deudor podría estar facilitando el paso a maquinaciones fraudulentas entre acreedor y solvens en perjuicio del deudor ${ }^{192}$.

Por lo demás, la doctrina, en general, estima que son admisibles todas las excepciones derivadas de la relación obligatoria habida con el acreedor, de modo que si el solvens pagó una deuda ya extinguida (v. gr. condonada, prescrita o pagada) nada podrá exigir al deudor. En este caso, sólo le quedará la vía directa en contra del acreedor por pago de lo indebido, asumiendo el tercero el consiguiente riesgo de insolvencia del acreedor.

También podrá el deudor, ignorante del pago, oponer como excepción la compensación que hubiere operado hasta el momento en que tuvo noticia del pago. Resulta de toda justicia que así sea ya que de haberse enfrentado personalmente al pago habría, antes, operado la compensación por el sólo ministerio de la ley, pudiendo alegarla contra su acreedor. Por lo demás, es

${ }^{191}$ Los autores que hacen la diferencia entre gestión y pago de tercero, distinguen también la acción de reembolso que compete al solvens, destacando que es mucho más amplia la acción de gestión. Véase Albiez Dohrmann, Klaus Jochen, cit. (n. 18), p. 54.

${ }^{192}$ Serra Callejo, Javier, cit. (n. 82), p. 1089. 
posible una aplicación analógica al caso de la cesión de derechos ignorada por el deudor, en que la ley concede a este último la posibilidad de oponer al cesionario la compensación de todos los créditos que antes de notificársele la cesión haya adquirido contra el cedente (artículo 1659 CC).

Por último, existe una razón de texto, que si bien, aplicada por vía analógica, resulta sumamente esclarecedora. Me refiero al caso del fiador, que siendo un tercero cualificado por su interés en el pago, puede realizarlo sin dar aviso al deudor y precisamente para ese caso el artículo 2377CC. dispone que el deudor podrá oponerle todas las excepciones de que él mismo hubiera podido servirse contra el acreedor al tiempo del pago. Incluso, si el deudor vuelve a pagar la deuda, por haber ignorado el pago del fiador, no podrá éste dirigirse en su contra, sino sólo contra el acreedor por el pago indebido. Si el deudor puede lo más, respecto de este tercero que, cualificado por su interés, no es extraño a la relación, también podrá lo menos, respecto del tercero ajeno totalmente a la relación.

En esta misma línea opera la solución del artículo 1905 CC, para el caso de la cesión de créditos que no ha sido notificada o aceptada por el deudor, en que resulta plenamente válido el pago efectuado por el deudor al cedente. Se trata se compatibilizar el interés del solvens, plenamente legitimado para pagar una deuda ajena con el que posee el deudor, que no ha hecho más que pagar a quien es para él el titular del crédito. Como no puede desconocerse que existen diferencias entre actuar por otro con su conocimiento que sin él, parece justo imponer al solvens la carga de dar aviso del pago al deudor, de modo que si no lo hace deberá soportar las consecuencias negativas de su omisión ${ }^{193}$. Con todo, considero que siempre podrá intentar la acción residual de enriquecimiento contra el acreedor.

En todo caso, como requisito previo a la acción de reembolso de que dispone el solvens contra el deudor, se establece su obligación de rendir cuenta regular de la gestión, con documentos justificativos o pruebas equivalentes, de modo que, estando comprendido en la gestión un pago por parte del solvens, habrá de comunicarlo al deudor en la señalada cuenta.

c) Pago de tercero con la oposición del deudor. En este caso, se trata de un tercero que también actúa a su propio nombre por cuenta del deudor, pero contra su voluntad. El artículo $1574 \mathrm{CC}$, que regula esta situación, niega al tercero acción de reembolso de lo pagado, a no ser que el acreedor le ceda voluntariamente su acción, es decir, lo subrogue convencionalmente ${ }^{194}$. Los elementos presentes en este caso son tres: el conocimiento

${ }^{193}$ Cfr. Bercovitz-Rodríguez Cano, Rodrigo - Valladares Rascón, Etelvina, cit. (n. 139), p. 54; y CAMPUZANo Tomé, Herminia, La intervención del tercero en una deuda ajena, en Actualidad civil, 45 (1989), p. 3521.

${ }^{194}$ Se aparta el Código chileno del francés, ya que admite la posibilidad de que el 
por parte del deudor de la intención de pago del tercero, su voluntad en contrario y la manifestación de esa voluntad al solvens antes o en el momento del pago (de lo contrario, podría presumirse una voluntad tácita en orden a aprobar el pago).

Para explicar esta situación podría sostenerse que el Código ha considerado que el pago efectuado por el tercero lo fue donandi causa y por ello le ha negado toda acción de regreso ${ }^{195}$. No es esta la interpretación que se ha dado en nuestro medio, ni tampoco forma parte de la discusión, aunque pueda haber sido esta la tendencia en otro momento de la historia ${ }^{196}$. En caso de alegar el deudor que se ha tratado de una liberalidad del solvens tendrá que probarlo.

La doctrina discute cual es el supuesto de hecho en este caso, de la opinión que se adhiera dependerán las posibilidades de resarcimiento del tercero. En general, es pacífico en la doctrina situar al tercero como un agente oficioso que interviene en el negocio ajeno contra la expresa prohibición del interesado ${ }^{197}$ y por ello el artículo 1574 presentaría una notoria contradicción con el artículo 2291 CC. ${ }^{198}$.

acreedor, voluntariamente le subrogue, lo que a la letra no permite el artículo $1236 \mathrm{CC}$. francés. Sin embargo, apunta Claro Solar, Luis, cit. (n. 19), p. 52, que la tendencia mayoritaria en la doctrina francesa es considerar que la no subrogación del tercero no es un requisito de este pago sino sólo un efecto.

${ }^{195}$ En el Anteproyecto de 1851 del Código Civil español el pago realizado contra la voluntad del deudor se consideraba una donación y por eso se negaba al solvens toda posibilidad de regreso. Véase: Hernández Moreno, Alfonso, cit. (n. 30), p. 110, donde analiza los comentarios de García Goyena al Proyecto de Código Civil español.

${ }^{196}$ Diez-Picazo, Luis, cit. (n. 2), p. 554.

${ }^{197}$ En contra: OвRеснт H., Raúl, La contradicción entre los artículos 1574 y 2291 del Código Civil es sólo aparente, en Revista de Derecho y Jurisprudencia, 39 (1942), "Derecho", pp. 99 y 100. Para este autor el tercero que paga contra la voluntad del deudor se rige por el artículo 1574 y no puede repetir, en cambio, si actúa como agente oficioso ya no se tratará del pago de un tercero o de deuda ajena, pues en este caso es el propio deudor que actúa, a través del agente y por ello, previa cuenta, puede exigir el abono de lo pagado conforme al artículo 2291. A pie de página se consigna la opinión de Gonzalo Barriga Errázuriz, en sentido contrario, descartando este autor que el artículo 1572 se refiera a casos de representación, si así fuera se extinguiría la deuda y no es eso lo que norman los artículos siguientes, sino las relaciones de regreso; la situación, explica, es la de un tercero que obra en su propio interés y no del deudor, por lo que sólo queda al acreedor decidir si lo subrogará o no, respetando en este último caso la voluntad del deudor. El artículo 1574 vendría a ser una sanción para este tercero.

${ }^{198}$ Por todos: Ramos Pazos, René, cit. (n. 24), pp. 349 y 350. Esta contradicción, en mi opinión sólo aparente, ya se destacaba en los primeros comentaristas del Código, Véase: Escala Barros, Enrique, Bello y el Código Civil chileno. Comentarios acerca de la obra 'Don Andrés Bello' de Eugenio Orrego Vicuña, en Cuadernos Jurídicos y Sociales. Universidad de Chile, (s/f), III, pp. 12 y 13. 
Una de las interpretaciones tradicionales que pretende salvar esta antinomia corresponde a Leopoldo Urrutia, quien distingue el campo de aplicación de cada una de estas normas sobre la base del concepto de utilidad del pago ${ }^{199}$. El artículo 1574 se aplicaría a un pago inútil del solvens, por lo que éste carece de derecho de regreso en contra del deudor y el artículo 2291 se aplicaría, en cambio, al pago útil al deudor, por lo que el solvens podrá repetir esta utilidad.

Se ha criticado a esta postura que ella distingue situaciones que el legislador no previó, es más, ninguna de las disposiciones de los artículos 1572 a 1574 CC. atiende a la utilidad del pago efectuado por el tercero, relegando la discusión sobre utilidad del pago a cada proceso concreto que se siga entre el tercero que pagó y el deudor, según sean o no admisibles las excepciones del deudor.

Otra línea interpretativa, también tradicional, corresponde a la tesis de Ruperto Bahamonde, para quien el ámbito de aplicación de las normas en conflicto es lo que resuelve la diferencia ${ }^{200}$. El artículo 1574 rige los pagos aislados realizados por un tercero y el artículo 2291 CC. regula, en cambio, aquellos pagos que forman parte de una administración de negocios ajenos, el pago sería una de las actividades desarrolladas por el gestor en el curso de una gestión más extensa.

Si bien la idea parece más conforme al tenor literal de los textos, la doctrina, en general, le critica lo poco equitativa que resulta la solución, ya que no se advierte cuál sería el fundamento para distinguir la situación de un pago aislado del que no lo es ${ }^{201}$. En ambos casos lo que se produce es un enriquecimiento por parte del deudor que ya no tendrá que pagar personalmente la deuda, de modo que si se le eximiese de todo reintegro hacia el solvens se producirá el injustificado enriquecimiento de aquél. En general, el resto de los autores nacionales comparte una u otra tesis con mayor o menor apego ${ }^{202}$. Así, hay autores que siguiendo a Bahamonde exigen, adicionalmente, que para la procedencia de una acción de reembolso por la utilidad, el pago debe comprenderse dentro de una gestión de negocios y haber reportado alguna utilidad al deudor, caso contrario, opera el artículo 1574 en cuya virtud

${ }^{199}$ Alessandri R., Arturo - Somarriva U., Manuel - Vodanovic, Antonio, cit. (n. 12), p. 22.

${ }^{200}$ Ibíd.

${ }^{201}$ Por todos: Ramos Pazos, René, cit. (n. 24), p. 350.

${ }^{202}$ Así, para Vial Del Río, Víctor, cit. (n. 8), pp. 323-324, la interpretación correcta consiste atribuir carácter de presunción simplemente legal a ambas normas: la del artículo 1574 en orden a que la oposición del deudor implica que el pago no le es favorable, sino al contrario, lo perjudica y la del artículo 2291, en cambio, presume que a pesar de la prohibición del deudor el pago le fue útil y por ello debe restituir al tercero. 
nada puede reclamar el solvens ${ }^{203}$. Otros, se inclinan por la tesis de Urrutia y conciben la aplicación del artículo 2291 para los casos en que el pago fue útil al deudor y del artículo 1574 CC. para aquellos casos en que no lo fue ${ }^{204}$.

En todo caso, de aplicarse esta última tesis, la acción de reembolso está limitada a lo que hubiere resultado útil al deudor existiendo esa utilidad al tiempo de la demanda. Así está preceptuado en el artículo 2291 CC., que incluso utiliza como ejemplo de gestión útil aquella de la que resulta la extinción de una deuda, que sin ella hubiera debido pagar el interesado. El pago, entonces, como modo de extinguir, se subsume plenamente en el supuesto de hecho de la norma ${ }^{205}$. Este ha sido también el criterio de varios autores nacionales, que solucionan la pretendida antinomia recurriendo al espíritu general de la legislación y a la equidad natural para dar cabida a la acción de enriquecimiento injusto en nuestro derecho ${ }^{206}$.

El reintegro, como tal, se haya limitado, en este caso, a la utilidad que el pago haya reportado al deudor, de modo que no corresponde necesariamente al "reembolso de lo pagado" como ocurre en el caso del artículo 1573 CC. En este sentido, a mi modo de ver, el artículo 1574 presenta un texto claro: no habrá derecho para el reembolso de lo pagado, que no es lo mismo que decir no habrá derecho alguno. El mismo Código regula un supuesto de hecho similar a la gestión de negocios ajenos contra la voluntad del dueño al tratar del derecho de regreso del fiador, disponiendo una solución distinta. De conformidad al artículo 2375 CC., no tendrá el fiador las acciones de reembolso concedidas en el artículo 2370, cuando se obligó contra la voluntad del deudor "[...] salvo en cuanto se haya extinguido la deuda, [...]"; es decir, si el pago ha sido perfecto, el fiador no sólo podrá repetir por lo útil que hubiere resultado el pago, sino que, gozando de la acción de reembolso ex artículo 2370 CC. se le permite recuperar intereses, gastos y perjuicios. Todo lo anterior demuestra que la tónica de los artículos 1572 a 1574 CC. no fue la de ir señalando las acciones de regreso de que disponía el solvens en cada caso, dejando el Código que se complementara cada régimen con normas dispersas a lo largo de su texto, así, los artículos 2158, 2290, 2370, 2375 y 2291 CC., entre otros, son los que concretan el alcance del reintegro.

Considero, entonces, que cuando el tercero ha pagado contra la voluntad

${ }^{203}$ BARriga Errázuriz, Gonzalo, cit. (n. 197), p. 100.

${ }^{204}$ Cfr. Claro Solar, Luis, cit. (n. 19), p. 49; y Stitchkin Branover, David, Derecho Civil (Santiago, Editorial Universitaria S.A., 1948), II, pp. 160 y 161.

${ }^{205}$ El artículo 1158 inciso $3^{\circ}$ CCEsp., se inclina por esta solución: si el pago ha sido hecho contra la expresa voluntad del deudor "[...] sólo podrá repetir del deudor aquello en que le hubiera sido útil el pago".

${ }^{206}$ Alessandri R., Arturo - Somarriva U., Manuel -Vodanovic, Antonio, cit. (n. 12), p. 23. 
del deudor y por ende, carece de la acción de reembolso, dispone de la acción de enriquecimiento injustificado ${ }^{207}$.

El deudor podrá oponer al solvens el daño experimentado con ocasión del pago, lo que la doctrina ha denominado enriquecimiento con daño simultáneo ${ }^{208}$, en que el solvens, al mismo tiempo que enriquece al deudor en un sentido amplio -de evitarle un gasto- le causa un daño al enriquecido deudor. Lo que ocurre en este caso es que el enriquecimiento es más aparente que real por lo que, frente a una reconvención del deudor demandado o sus excepciones, el juez habrá de proceder a una verdadera compensación. En todo caso, el deudor, al alegar el perjuicio que el pago le ha producido, deberá acreditar la concurrencia de los requisitos propios del daño. De este modo, si pretende oponerse a la restitución alegando la proximidad de una prescripción extintiva (no cumplida al tiempo del pago) habría que rechazar el argumento porque el deudor en estos casos no tiene un derecho adquirido sino meramente una expectativa, que puede ser frustrada en cualquier momento en que el acreedor intente satisfacerse y uno de los medios legítimos de satisfacción de su crédito es precisamente el pago de un tercero.

Debe tenerse presente que la medida de la restitución viene dada por el enriquecimiento experimentado y no por el empobrecimiento del solvens, es por ello que el reintegro alcanza hasta donde el pago hubiere sido útil. Claramente no se trata de una acción de responsabilidad extracontractual derivada de daño, pues si así fuera, la medida del reintegro estaría dada por la magnitud del empobrecimiento -daño- del solvens y no como ocurre en estos casos, en que la medida es el enriquecimiento del deudor ${ }^{209}$.

Esta postura se topa con uno de los tres requisitos de procedencia que la doctrina ha exigido para que prospere la acción in rem verso: la ausencia de culpa del que pretende la restitución. Si bien la figura goza de cierta objetividad en cuanto a su apreciación, ya que se trata de una atribución patrimonial en un sujeto sin una causa legítima, es atendible exigir al demandante haber actuado con diligencia, con ello no se está suponiendo una ausencia total de culpa ya que siempre o casi siempre habrá de por medio algún grado de torpeza o error. Precisando el requisito se ha dicho: a) basta que no se trate de un hecho ilícito, por lo que "si el empobrecido se ha rebelado contra

${ }^{207}$ Claro Solar, Luis, cit. (n. 19), p. 52, habla de una acción in rem verso para demandar aquello en que el pago fue realmente útil al deudor. Para un estudio más acabado en las fuentes romanas, Véase: Bayo Recuero, Nieves, cit. (n. 27), pp. 32 y 33, donde señala que han dado esta solución, inspirada en Paulo, D. 17.1.40, autores como Maynz, para quien el solvens podrá ejercitar la actio in rem verso, por tratarse de una acción de enriquecimiento injusto.

${ }^{208}$ Peñailillo Arévalo, Daniel, cit. (n. 120), p. 105.

${ }^{209}$ Ibíd., p. 106 
el orden jurídico, en términos que si no se hubiere puesto al margen del derecho su empobrecimiento no se habría producido, la situación se torna intolerable y él mal puede pretender el amparo del orden jurídico al cual no vaciló en agredir"210, nos parece que este no es el caso ya que el artículo 1572, independientemente de los efectos, otorga una legitimación amplia para que un tercero pague, aun contra la voluntad del deudor; y b) que no se trate de un caso de expresa asunción del riesgo por parte del demandante, como cuando actúa con pleno conocimiento y aceptación del riesgo que implica su actuación, en este caso, es natural entender que la persona ha asumido ese riesgo.

Para Peñailillo el artículo 1574 CC. es un caso claro de esta última situación y por ello pareciera considerar que no se daría el requisito de ausencia de culpa, por lo que sería improcedente el reintegro. Con todo, me parece que ponderar el grado de diligencia será una cuestión de hecho que dependerá de las circunstancias del caso. Tratándose de la gestión de negocios ajenos no debe olvidarse que el fin perseguido por el gestor es evitar un perjuicio inminente al dueño del negocio, que en el caso del pago resulta evidente por cuanto el gasto era de todos modos necesario, es decir, la actuación del solvens ha satisfecho una necesidad, de modo que si no hubiese intervenido, de todas maneras habría tenido que actuar el deudor para satisfacerla; más aún, si la necesidad de pagar no era tal para el deudor, podrá oponer sus excepciones al solvens y quedar de todos modos protegido de la intromisión del tercero.

De acuerdo con lo dicho, entonces, el deudor puede oponer al solvens las excepciones derivadas de su relación con el acreedor, todas ellas destinadas a refutar la utilidad del pago por cuanto de haberlas opuesto al acreedor la deuda habría sido menor o nula.

En cuanto al carácter principal o subsidiario de la acción, es pacífico en la doctrina su carácter residual, a pesar de su origen histórico, ya que en Roma la acción in rem verso no tenía carácter subsidiario. Asimismo, la mayoría de los ordenamientos extranjeros que la contemplan en forma expresa, regulan su ejercicio en defecto de una acción específica para obtener el resarcimiento ${ }^{211}$.

A pesar que la doctrina se decanta mayoritariamente por la opción de su carácter residual, cabe preguntarse qué pasaría en el caso que el demandante no reuniese todos los requisitos para intentar la acción específica que le concede el ordenamiento. ¿Puede en ese caso recurrir a la de enriquecimiento?

${ }^{210}$ Ibíd., p. 113.

${ }^{211}$ Así los Códigos italiano, peruano y portugués. Sin embargo, advierte PEÑAILILlo ArÉvalo, Daniel, cit. (n. 120), p. 116, existe una fuerte tendencia de la doctrina francesa a considerar que puede presentarse la situación de cúmulo u opción de acciones, como ocurre en el derecho alemán. 
Peñailillo hace una distinción interesante a nuestros efectos, ya que señala se debe investigar por qué no se reúnen todos los requisitos, es decir, determinar si el sujeto se halla en una situación que el propio ordenamiento permite en la ausencia de dichos requisitos, v. gr. el comprador de cosa mueble que ha sufrido lesión en el precio, o bien si la acción específica sólo tenía por objeto colocar al empobrecido en una situación ventajosa para accionar. En este último caso, el autor se inclina por otorgar la acción y pone el ejemplo de aquél que presta un servicio a otro sin mediar el correspondiente contrato de trabajo.

En el caso que nos ocupa, podríamos pensar, entonces, que la situación del tercero que paga contra la voluntad del deudor corresponde a una de este segundo grupo, es decir, al tercero solvens se le niega la acción derivada del mandato por no contar con la aprobación para el pago, tampoco tiene la acción de reembolso de lo pagado derivada de la agencia oficiosa, sólo tendrá acción para recuperar lo efectivamente útil al deudor: la acción derivada del enriquecimiento injusto.

La cuantía del reintegro viene determinada expresamente por la ley, el artículo 2291 CC. exige, primeramente, que el pago haya reportado una utilidad efectiva al deudor ya que sólo se puede demandar el monto de dicha utilidad. Se exige, además, que esa utilidad exista al tiempo de la demanda. Esta disposición deja en evidencia que lo que el legislador está regulando no es una cuestión indemnizatoria a favor del tercero, en cuyo caso el artículo 1574 no le habría denegado la acción y el monto a restituir sería el total pagado por el solvens, equivalente al daño en su patrimonio, lo que aquí se regula es una situación de atribución patrimonial sin causa en la persona del deudor, que la ley no favorece y por ello el monto a reintegrar será solamente la parte correspondiente al enriquecimiento experimentado.

Junto con descartar el animus donandi del tercero que paga, habría que descartar también que lo haga solvendi causa en cumplimiento de un contrato, a título de contraprestación, o como deudor delegado del deudor ${ }^{212}$. En estos casos, por razones obvias, no se abre la vía de regreso para el tercero.

\section{INTENSIDAD DE LA LEGITIMACIÓN DEL TERCERO}

Hemos visto como la ley, reconociendo que son legitimados para el pago todos los terceros, ha ido modelando los efectos de ese pago según el interés que ese tercero haya podido tener en el pago y a falta de un interés especialmente cualificado, según si el pago contó o no con el conocimiento o la aprobación del deudor. Queda por analizar la intensidad de la legiti-

${ }^{212}$ Gómez-Blanes, Pablo, cit. (n. 68), p. 2385. 
mación del tercero, es decir, hasta qué punto puede el tercero imponer el pago, o desde otro punto de vista, si existen límites al pago de tercero, casos en los que el tercero, contra la regla general del artículo 1572 CC, no puede imponer el pago.

Respecto del deudor, la legitimación es amplia y la ley valida el pago hecho aún contra su voluntad. En cuanto al acreedor, también es válido el pago hecho contra su voluntad, que sería el caso de imponerle el pago mediante la consignación ${ }^{213}$.

Entonces, cabe preguntarse si todos los terceros poseen la facultad de consignar, ya no de pagar, por cuanto la legitimación, como vimos, es universal. Claro Solar advertía que puede comprenderse la facultad en aquellos terceros interesados en el cumplimiento, más no en el caso de los terceros absolutos, aquellos que son extraños a la obligación. Citando a Pothier considera admisible sólo el pago impuesto por el tercero interesado, con lo que el acreedor podría oponerse justificadamente al pago que le ofrece un tercero extraño absoluto y que no represente ventaja para su deudor, mas reconoce que esta doctrina no llegó a concretarse en el Code, cuyo artículo 1236, es tan amplio como nuestro $1572 \mathrm{CC}^{214}$.

Nuestra jurisprudencia ha reconocido la amplia facultad de pagar que tiene el tercero y la ha aplicado también al pago por consignación. Al respecto y pronunciándose sobre un caso de pago por consignación efectuado en la ignorancia del deudor, ha dicho que "[...] la suficiencia del pago debe discutirse obligadamente entre el tercero que paga y el acreedor, por aplicación de lo previsto en los artículos 1573 y 1574 del Código Civil, por lo que la suficiencia del pago no se plantea entre el deudor y acreedor [...]"215.

Tampoco resulta discutido en nuestra doctrina que el tercero, así como está siempre facultado para pagar y tratándose la consignación de un pago,

${ }^{213}$ Si bien el acreedor no viene obligado a ejercer su derecho, se impone la consideración del interés del deudor de verse liberado de su obligación, lo que para algunos constituye un verdadero derecho de cumplimiento por parte del deudor y por ese motivo debe sufrir los efectos de la mora creditoris cuando se niega o no presta la colaboración necesaria. No se conceden al deudor los remedios propios del incumplimiento, sino que, primeramente, la posibilidad de constituir al acreedor en mora y seguidamente, la facultad de consignar para liberarse totalmente de la obligación.

${ }^{214}$ Claro Solar, Luis, cit. (n. 19), p. 50.

${ }^{215}$ Corte Suprema, 12 de junio de 2000, en LegalPublishing No 16.986; y en Revista de Derecho y Jurisprudencia, 97 (2000), 2 a parte, sec. $1^{\text {a }}$, p. 110. En este caso, de cobro de pesos, el tercero opuso como excepción la falta de legitimación pasiva por no ser deudor del demandante, sino un tercero. La Corte rechazó la excepción estimando que, habiendo consignado un tercero, la cuestión de fondo era la suficiencia del pago efectuado y era legítimo contradictor el tercero que había pagado por consignación. 
esté también legitimado para consignar ${ }^{216}$. A ello cabe agregar que no hay razón de texto que lo impida, sino al contrario, el artículo $1572 \mathrm{CC}$. dispone expresamente que el pago puede ser hecho por el tercero "aun a pesar del acreedor", el artículo 1569 inciso $2^{\circ} \mathrm{CC}$. establece: "El acreedor no podrá ser obligado a recibir otra cosa que lo que se le deba [...]". Estas normas, interpretadas en sentido contrario, indican que el acreedor puede ser obligado a recibir el pago perfecto que le ofrece cualquier persona a nombre del deudor. Desde el momento que lo rechace caerá en el ámbito de aplicación del artículo 1598 y ss. CC. También el artículo 1600, al regular los requisitos de la oferta válida, se expresa, una vez más, en términos impersonales " $1 .{ }^{a}$ Que sea hecha por una persona capaz de pagar" es decir, que tanto el deudor como un tercero que reúnan los requisitos establecidos en la disposición podrán pagar válidamente por consignación.

Podemos decir, entonces, que en nuestro derecho legitimación para el pago es lo mismo que legitimación para consignar, se corresponden plenamente ${ }^{217}$.

\section{Limites al pago de tercero derivados del tipo de obligación. Objetivos y subjetivos.}

Una primera limitación al pago de tercero emana de la propia norma que concede la legitimación al tercero, el artículo 1572 CC., al referirse a las obligaciones de hacer en que se haya tomado en consideración las especiales facultades y aptitudes del deudor; en estos casos, no podrá el acreedor ser obligado a aceptar el pago de otra persona que el deudor. Me remito, por lo tanto a lo ya señalado al tratar de los presupuestos necesarios para el pago de tercero, específicamente, que se trate de una obligación que admita ser cumplida por un tercero.

Así como esta primera limitación emana de la naturaleza misma de la obligación y sólo se refiere a las obligaciones de hacer, podría ya no la naturaleza de las cosas, cuestión objetiva, sino la calidad del tercero ser obstáculo al cumplimiento, lo que se ha denominado límite subjetivo al pago de tercero ${ }^{218}$ y nos permite indagar en las obligaciones de dar ${ }^{219}$. Necesariamente es así

${ }^{216}$ Por todos, Abeliuk Manasevich, René, cit. (n. 7), p. 582.

${ }^{217}$ No ocurre así en otros derechos como el alemán, en que el tercero que desea pagar por consignación debe tener "derecho de satisfacción" y este se concede sólo a ciertos terceros interesados, Véase: Cano Hurtado, María Dolores, cit. (n. 15), p. 286.

${ }^{218}$ Cfr. Nicolò, Rosario, cit. (n. 58), pp. 119-125. Explica que el límite objetivo sólo se da respecto de las obligaciones de hacer, mas no en las de dar, pues si la cosa específica que debe darse está en manos de un tercero el deudor podrá excepcionarse por imposibilidad en el cumplimiento.

${ }^{219}$ Esta cuestión se plantea en la doctrina italiana cuya norma equivalente al artícu- 
porque las obligaciones de hacer sólo admiten límite objetivo (la naturaleza misma de la obligación lo impone) toda vez que la prestación consiste en la actividad de una determinada persona, por ello personalísimas o infungibles; en cambio, las obligaciones de dar sólo admiten límite subjetivo pues los medios para alcanzar la prestación son sustituibles.

Dentro de los límites subjetivos, que ampararían al acreedor para rechazar el pago, encontramos la norma del artículo 1575 CC., que requiere ciertas calidades especiales en el solvens ${ }^{220}$, de modo que si ellas no concurren el acreedor podría rechazar el pago, para no verse sujeto a la posible invalidez del pago y consiguiente repetición. Esta limitación al pago de tercero viene de algún modo recogida en el artículo 1600 № 1 CC., al referirse a los requisitos que debe reunir la oferta válida para la consignación: que sea hecha por una persona capaz de pagar. Es capaz de pagar, en el caso de la obligación de dar, el dueño con facultad de enajenar, de modo que, si faltan estas circunstancias en el solvens y por ello el acreedor le rechaza el pago, el tercero tampoco podrá imponérselo pues no cuenta con legitimación suficiente para consignar. No se producirán entonces las consecuencias de la mora creditoris ya que este tercero no ha tenido la virtualidad de constituir en mora al acreedor.

De este modo, sí parece posible un límite al pago de tercero fundado, ya no en la naturaleza de la obligación, sino en la ausencia de alguna calidad que admita el rechazo del pago, incluso del que pretende imponerse coactivamente. Con todo, este límite, a diferencia del que implican las obligaciones de hacer personalísimas, es sólo relativo y no absoluto, pues sólo se puede oponer al tercero incurso en la limitación.

\section{Limites derivados de la convención de las partes.}

A pesar de los amplios términos en que está concebida la legitimación para el pago, que prescinde de la voluntad unilateral del deudor y del acreedor, la ley nada ha dicho frente a una voluntad concorde de ambos sujetos en contra del pago que ofrece un tercero. Este vacío de nuestra legislación ha sido materia legislada en otras codificaciones, sobre todo en aquellas más modernas que la nuestra, así como también objeto de estudio por parte de la doctrina extranjera. La cuestión a resolver, en nuestro derecho, dice relación, primeramente, con la validez o eficacia que pueda tener un pacto entre acreedor y deudor por el cual se opongan al pago del tercero. Para ello debemos definir qué tipo de norma es la que contiene el artículo 1572 CC.

lo 1572 inciso $2^{\circ} \mathrm{CCCh}$., es el artículo 1180 CCIt., que no habla de obligación de hacer sino que, en términos más amplios, acepta la oposición al pago por parte del acreedor cuando éste tenga interés en que el deudor cumpla en forma personal.

${ }^{220} \mathrm{El}$ artículo 1575 CC. exige al solvens ser dueño de la cosa pagada o pagar con el consentimiento del dueño y poseer facultad de enajenar. 
y así determinar si puede ser derogada por las partes y este pacto oponible al tercero que intenta el pago ${ }^{221}$.

En principio, podría decirse que es perfectamente legítimo dentro de los márgenes de la autonomía de la voluntad un pacto entre acreedor y deudor por el cual rechacen la posible intervención de un tercero en el pago en consideración a su interés en que el cumplimiento sea llevado a cabo por el deudor originario. En efecto, puede ocurrir que en determinadas circunstancias contractuales al acreedor y al deudor les interese mantener una relación duradera y no deseen la injerencia ajena en sus negocios, es decir, suponemos la existencia de un interés negocial entre ambos que sea suficiente para acordar que la obligación sólo podrá ser pagada por el deudor.

Este pacto supone la renuncia, para ambos, del derecho que les concede el artículo 1572 CC., en orden a que pueda realizar el pago un tercero; desde este punto de vista, debe aplicarse lo dispuesto en el artículo 12 CC., es decir, podrán renunciar sus derechos en cuanto miren a su interés individual y su renuncia no esté prohibida ${ }^{222}$. Me parece necesario distinguir la situación antes y después del pago. Hasta antes del pago, el artículo 1572 sólo vela por el interés del acreedor en ver satisfecho su crédito y del deudor por liberarse de la obligación, extinguiéndola; desde este punto de vista la norma aparece como plenamente disponible para las partes, lo que no ocurre después del pago. Concurre en apoyo de estas ideas el sentido y fundamento del pago del tercero ${ }^{223}$; y es que el pago de tercero a nadie perjudica, por el contrario, a todos beneficia; al acreedor, ya que a este sólo interesa que se le pague, no

${ }^{221}$ Cfr. Josserand, Louis, Derecho civil. Teoría general de las obligaciones (trad. S. Cunchillos y Manterola, Buenos Aires, Bosch, 1952), II, 1, p. 668, admite el pacto pero quedan las partes sujetas a la responsabilidad que pudiera acarrearles una posible "colusión con ánimo de atentar contra los intereses legítimos de una tercera persona, por ejemplo, para hacer caer una hipoteca de éste mediante la acción de resolución del vendedor que, con ese objeto, quiere continuar impagado y se niega, por consiguiente, a recibir el pago de manos de una persona extraña a la deuda”. Esta situación tiene fácil solución por la vía de la consignación, que en caso de un tercero interesado, como el del ejemplo, puede imponerla al acreedor.

${ }^{222}$ Para el evento de infringirse el pacto, Del Olmo García, Pedro, Los limites al pago de tercero y la legitimación para consignar, en Anuario de Derecho civil, 52 (1999), 1, pp. 204-205, considera que debe aplicarse un criterio similar al que resuelve el caso de las obligaciones sujetas a plazo, en que puede renunciarse al plazo según a quien beneficie su establecimiento. Si el acreedor es el beneficiario del pacto éste conservará siempre su derecho a recibir la prestación de un tercero y si lo es el deudor, podrá también acudir a un tercero que cumpla por él. Hace notar este autor que lo anterior se aplica sólo a las obligaciones de dar ya que en las de hacer el pacto cambia la identidad misma de la prestación.

${ }^{223}$ Por todos, Alessandri R., Arturo - Somarriva U. - Manuel y Vodanovic, Antonio, cit. (n. 12), p. 18. 
le importa quien lo haga; al deudor, que puede no hallarse en condiciones de pagar y puede así esquivar la agresión del acreedor extinguiendo su deuda y que, en todo caso, no ve perjudicada su situación sino sólo alterada por cuanto deberá reembolsar al que pagó ${ }^{224}$. Luego, sólo estaría comprometido en un pacto modificatorio el interés de las partes de la relación obligatoria y atendido que la finalidad del artículo 1572 CC. es tutelar el interés del acreedor y del deudor contra la negativa injustificada de la otra parte, la norma puede ser alterada por la voluntad de las partes. Hasta aquí no pareciera existir un motivo de orden público, como la fluidez y agilidad en el tráfico, de tanta envergadura como para justificar la intromisión de un tercero cualquiera en la esfera ajena contra la voluntad de las partes contratantes.

La situación cambia si incorporamos al análisis la norma del artículo 1610 CC., que introduce, sin expresarlo, el concepto de tercero interesado, aquél que la ley subroga por el sólo hecho del pago. Como hemos dicho, en general, estos terceros son los que están sujetos al poder de agresión del acreedor o bien la consolidación de su derecho depende, en parte, del pago y por ello al pagar no realizan un acto totalmente libre. Lo anterior ha sido materia de regulación expresa en los ordenamientos civiles de Portugal ${ }^{225} \mathrm{y}$ Alemania $^{226}$, a través del reconocimiento en distinto grado, de un verdadero derecho de cumplimiento de estos terceros que les permite imponer el pago aún en el evento de la oposición conjunta de acreedor y deudor ${ }^{227}$. No

${ }^{224}$ En la doctrina extranjera las opiniones están divididas, a favor de este pacto, entre otros: Beltrán de Heredia y Castaño, José, cit. (n. 14), p. 136; en contra: Bercovitz y Rodríguez Cano, Rodrigo - Valladares Rascón, Etelvina, cit. (n. 139), pp. 26-27. Véanse también: Del Olmo García, Pedro, Los límites, cit. (n. 222), pp. 145-207; y Cano Hurtado, María Dolores, cit. (n. 15), pp. 282-296.

${ }^{225} \mathrm{El}$ artículo 768 inciso $2^{\circ}$ del Código Civil portugués dispone que el acreedor puede rehusar el pago del tercero cuando el deudor se opone a él y se trate de un tercero que no pueda subrogarse conforme al artículo 592. Por su parte, este último dispone, en su inciso $1^{\circ}$, que los terceros que cumplen la obligación se subrogan legalmente en los derechos del acreedor cuando hubieren garantizado su cumplimiento o cuando, por otra causa, estuvieren directamente interesados en la satisfacción del crédito. [traducción libre de la autoría].

${ }^{226} \mathrm{El} \$ 268$ BGB. establece dos casos en que el tercero tiene derecho a cumplir la obligación ajena, $1^{\circ}$ : el titular de un derecho real sobre un objeto perteneciente al deudor cuando, por una ejecución forzosa promovida por el acreedor, se ve en peligro de perder su derecho en la subasta judicial y $2^{\circ}$ : el poseedor de una cosa si corre el peligro de perder la posesión por la ejecución forzosa. LAMARCA MARQUÈs, Albert (director y traductor) Código Civil Alemán y Ley de introducción al Código Civil (Madrid, Marcial Pons, 2008).

${ }^{227}$ En la doctrina italiana, Di MAJO, Alfonso, cit. (n. 66), pp. 53 y 62-69, ha estimado que se trata de una auténtica laguna legal, no obstante pareciera también inclinarse por tutelar el interés de estos terceros y lo hace exigiendo al acreedor un interés "apre- 
obstante y como ya hemos señalado, el Código ha sido detallista al indicar los casos de subrogación legal, a diferencia de otros, que utilizan el concepto de tercero interesado para conferirle el beneficio subrogatorio. Ello nos plantea la necesidad de distinguir los casos en que verdaderamente podría presentarse el conflicto entre el pacto de las partes y el interés del tercero en pagar, para luego determinar si el interés del tercero resulta capaz de resistir el pacto entre acreedor y deudor.

Así, no se dará el supuesto en estudio cuando se trate de los casos de subrogación contemplados en el artículo $1610 \mathrm{~N}^{\circ} \mathrm{s} 4,5$ y 6 CC.; respecto del heredero beneficiario no se presentará conflicto ya que el heredero es deudor, en el caso del № 5 , tampoco, ya que el supuesto de hecho que allí se contempla exige un pago efectuado con el consentimiento del deudor y en el $\mathrm{N}^{\circ} 6$, porque en este caso el pago lo realiza el propio deudor. Tampoco habrá lugar a conflicto en el caso del codeudor solidario dado su carácter de deudor directo frente al acreedor.

Distinta es la situación de los $\mathrm{N}^{\mathrm{o}} \mathrm{s}$, 2 y 3 del artículo 1610 CC., en que considero que existe un interés atendible del tercero que permite la inoponibilidad del pacto, más aún teniendo en cuenta que él implica la renuncia de derechos por parte del acreedor y del deudor y esta renuncia sólo valdría cuando mire al interés individual de los renunciantes. En estos casos se tratará precisamente de un tercero (un no deudor o un no deudor exclusivo) que está o podría llegar a estar expuesto a la agresión del acreedor, su interés en cumplir debe quedar suficientemente amparado por la ley, sino como un derecho, al menos como un interés vigorosamente tutelado ${ }^{228}$.

Frente a esta legitimación cualificada para el pago nada pueden hacer las partes ya que no está en juego su sólo interés sino que el de estos terceros, que es de suficiente envergadura como para imponer el pago, aún contra la voluntad conjunta de ambos, acreedor y deudor, mediante la consignación.

ciable" o legítimo para oponerse al pago. Por su parte Cattaneo, Giovanni, Della mora del creditore, en Galgano, Francesco (director), Commentario del Codice civile, Scialoja-Branca (articulo 1206-1217) (Bolonia-Roma, Zanichelli, 1973), p. 100; y CARPIno, Brunetto, Del pagamento con surrogazione, en Galgano, Francesco (director), Commentario del Codice civile, Scialoja-Branca (artículo 1201-1205) (Bolonia-Roma, Zanichelli, 1988), p. 96, se refieren al adquirente de un bien hipotecado y al tercero que hipotecó su propio bien en garantía de una deuda ajena como terceros especialmente legitimados para vencer la oposición conjunta al pago de acreedor y deudor.

${ }^{228} \mathrm{Si}$ el interés del deudor en el cumplimiento y liberación tuviese la naturaleza de derecho habría que configurar, asimismo, la carga del acreedor de cooperar como un deber jurídico equivalente a la obligación, ello no ocurre así. No obstante, para algunos autores esta exigencia de tutela del interés del tercero debe concretarse en reconocerles un derecho a cumplir, Véase: Bianca C., Massimo, Diritto civile (Milano, Giuffré, 1987-95),VI, pp. 288-289. 
Estimo, en consecuencia, que a estos terceros les es inoponible el pacto por el que las partes excluyan su injerencia en el pago.

\section{Conclusiones}

1. El pago por tercero no es habitualmente previsto por las partes, sino que suele darse en forma que sustituye el acuerdo original proyectado al concertar la relación obligatoria, pero que, por atender al interés del acreedor en obtener la prestación y eventualmente también al interés del deudor en liberarse de la deuda, ha sido ampliamente aceptado por el Derecho como una forma de cumplimiento. En aras del interés del acreedor el deudor no puede oponerse al pago de un tercero y en aras del interés del deudor, tampoco puede rechazar el pago el acreedor.

Como lo normal es que las partes que contratan lo hagan teniendo en vista que el cumplimiento se llevará a cabo por quien asume la calidad deudora, generalmente en la confianza que ello va a ocurrir, la función que la ley cumple al regular el pago de tercero es eminentemente dispositiva, dirigida a resolver una situación que no fue originalmente prevista al nacer la obligación. De allí que las normas que regulan la materia puedan ser modificadas o aún derogadas por la voluntad de las partes, al menos hasta antes de entrar en un posible conflicto con el interés del tercero que ha pagado, caso en que ya nada podrán hacer pues sólo al tercero le compete renunciar a su derecho.

2. Ahora bien, todo lo anterior es aplicable en términos generales, salvo en cuanto nos encontremos frente a un tercero que tiene algún interés comprometido en el cumplimiento de la obligación. No cualquier interés, sino uno de especial relevancia jurídica, ante el cual la propia ley ha optado por restringir la autonomía de la voluntad de las partes. Lo que da fisonomía a este interés es la eventualidad de sufrir el tercero la agresión del acreedor y querer, por ello, evitarlo mediante el pago. Prescindiendo, entonces, de la voluntad de las partes, ha reforzado la legitimación de este tercero al punto que puede llevar a cabo el pago superando la voluntad conjunta de acreedor y deudor y sin extinguir la obligación sino que apropiándosela, con todas sus garantías, a efectos de asegurarse el reintegro.

3. No se piense, sin embargo, que por medio de la subrogación la ley sólo ha querido beneficiar o mirar al interés del solvens, al contrario, la institución no perjudica a las partes de la relación obligatoria y trae ventajas para ambos: el acreedor originario ve efectivamente satisfecho su crédito, superando el riesgo de insolvencia de su deudor, mediante un pago perfecto, pues han de respetarse los principios de identidad e integridad del pago (de presentarse alguna consecuencia negativa ella sólo podrá haber sido libremente acordada mediante la subrogación convencional; por otra parte, si acepta un pago 
parcial la ley le otorga preferencia para el pago del remanente); el deudor podrá obtener un plazo mayor para recuperar las fuerzas de su patrimonio, u obtener un crédito en mejores condiciones de mercado (subrogación ex mutuo); en todo caso, si el nuevo acreedor resultare ser más rígido ello es irrelevante desde el punto de vista jurídico, es más bien un riesgo propio del tráfico.

Tampoco se perjudican otros terceros, el subrogado no adquirirá un crédito de mayor cuantía o de mejor condición que el pagado.

4. La subrogación rompe el rígido principio de que toda obligación se extingue por su solución o pago. Este es el efecto normal cuando paga el deudor o un tercero extraño, pero no cuando lo hace un tercero cualificado, que se subroga por ley.

$\mathrm{Al}$ tercero extraño la ley sólo le otorga una legitimación simple, en el sentido que su pago sólo puede producir los efectos normales de todo pago y no uno distinto, como sería el efecto subrogatorio que impide la función liberatoria del deudor. A la inversa, aquellos terceros no extraños, entre los que incluimos al codeudor solidario y al deudor subsidiario en lo ajeno que pueda resultarles la deuda, poseen una legitimación cualificada para el pago, en un doble sentido: pueden pagar sin extinguir la deuda, mediante el efecto subrogatorio y además, pueden imponer el pago resistiendo la voluntad conjunta del acreedor y del deudor, mediante la consignación, cosa que no puede hacer el tercero absoluto, que no posee un interés propio cualificado.

5. La legitimación reforzada de estos terceros no es universal ni esta destinada a la extinción, es por lo tanto excepcional. Algún autor la ha calificado, por lo mismo, como legitimación arbitraria ${ }^{229}$.

6. Con todo y a pesar de existir dos clases de legitimación del tercero para el pago, pueden mantenerse, como principios, que cualquier tercero que paga una deuda ajena tiene un derecho personal contra el deudor y que su interés es la medida de los efectos del pago.

Ello es así toda vez que el fundamento de la subrogación y demás acciones de regreso de que dispone el solvens radica en evitar un enriquecimiento injusto por parte del deudor a expensas del tercero que paga; lo diferenciador, entre ambas es que sólo mediante la subrogación se refuerza la posición jurídica del tercero al punto que su legitimación para el pago, además de ser universal, es capaz de vencer la voluntad conjunta del acreedor y deudor y de colocarle en las mejores condiciones posibles para el regreso al dejar subsistente el crédito originario con todas sus garantías.

${ }^{229}$ Hernández Moreno, Alfonso, cit. (n. 30), p. 156. 


\section{BiBLIOGRAFÍA}

Abeliuk Manasevich, René, Las obligaciones (4a edición, Santiago, Editorial Jurídica de Chile, 2005), II.

Aguad Deik, Alejandra - Pizarro Wilson, Carlos, Comentarios de jurisprudencia. Obligaciones y responsabilidad civil, en Revista Chilena de Derecho Privado, 14 (2010).

Albaladejo García, Manuel, Derecho civil (9a edición, Barcelona, Bosch, 1994), II.

Albiez Dohrmann, Klaus Jochen, El pago por tercero, en Cuadernos de Derecho Judicial, 26 (1996).

AlCalde Silva, Jaime, Las cartas de patrocinio. Criterios dogmáticos para su aplicación en Chile (Santiago, Abeledo Perrot - LegalPublishing, 2010).

Alessandri R., Arturo - Somarriva U., Manuel - Vodanovic, Antonio, Tratado de las obligaciones (2a edición, Santiago, Editorial Jurídica de Chile, 2001), II.

Alessandri Rodríguez, Arturo, Del traspaso del derecho de hipoteca en el pago con subrogación, en Revista de Derecho y Jurisprudencia, 20 (1924).

Alessandri Rodríguez, Arturo, Teoría de las obligaciones. Derecho civil, $2^{\circ}$ año, versión taquigráfica de sus clases por Ramón Latorre Z. (Santiago, Zamorano y Caperán, 1934).

Alessandri Rodríguez, Fernando, La hipoteca en la legislación chilena (Santiago, Soc. Imprenta y litografía Universo, 1919).

Alonso Sánchez, Beatriz, Protección del fiador en vía de regreso (Madrid, Tecnos, 1993).

ArCe Flórez-Valdés, Joaquín, Extinción del contrato y de las relaciones que nacen del mismo, en Vattier, Carlos y otros (directores), Código Europeo de Contratos. Comentarios en homenaje al Prof. D. José Luis de los Mozos y de los Mozos (Madrid, Dykinson, 2003), II.

BARAONA GonZÁlez, Jorge, El retraso en el cumplimiento de las obligaciones (Madrid, Dykinson, 1998).

BARRIGA ERRÁzURIZ, Gonzalo, comentario a La contradicción entre los artículos 1574 y 2291 del Código Civil es sólo aparente de Raúl Obrecht H., en Revista de Derecho y Jurisporudencia, 39 (1942).

Bayo Recuero, Nieves, El pago del tercero (Madrid, Dijusa, 2000).

Bello, Andrés, Obras completas (Santiago, Imprenta de Pedro G. Ramírez, 1887), $\mathrm{XI}$.

Beltrán de Heredia y Castaño, José, El cumplimiento de las obligaciones (Madrid, Editorial Revista de Derecho Privado, 1956).

Bénabent, Alain, Droit civil. Les obligations ( $11^{\text {a }}$ edición, París, Librairie Générale de Droit et de Jurisprudence, 2007).

Bercovitz y Rodríguez Cano, Rodrigo - Valladares Rascón, Etelvina, en Albaladejo, Manuel - Díaz Alabart, Silvia (coordinadores), Comentarios al Código Civily Compilaciones Forales (2a edición, Madrid, Edersa, 1991), XVI, 1.

Betti, Emilio, Teoría general de las obligaciones (trad. J. L. de los Mozos, Madrid, Ed. Revista de Derecho Privado, 1969), I.

Bianca C., Massimo, Diritto civile (Milano, Giuffré, 1987-95), VI.

Bondía Román, Fernando, La subrogación en el crédito, en Estudios de Derecho civil en homenaje al profesor Dr. José Luis Lacruz Berdejo (Zaragoza, Bosch, 1993), II. 
Campuzano Tomé, Herminia, La intervención del tercero en una deuda ajena, en Actualidad civil, 45 (1989).

Cano Hurtado, María Dolores, La consignación como mecanismo de liberación del deudor (Madrid, Dykinson, 2005).

Cañizares Laso, Ana, El pago con subrogación (Madrid, Civitas, 1996).

CARPIno, Brunetto, Delpagamento con surrogazione, en Galgano, Francesco (director), Commentario del Codice civile, Scialoja-Branca (artículo 1201-1205) (Bolonia - Roma, Zanichelli, 1988).

Cattaneo, Giovanni, Della mora del creditore, en Galgano, Francesco (director), Commentario del Codice civile, Scialoja-Branca (articulo 1206-1217) (Bolonia Roma, Zanichelli, 1973).

Claro Salas, Héctor, Un caso de pago con subrogación, en Revista de Derecho y Jurisprudencia, 8, (1911).

Claro Solar, Luis, Explicaciones de Derecho civil chileno y comparado (ed. facsimilar, Santiago, Editorial Jurídica de Chile, 1979), XII.

Colin, Ambroise - Capitant, Henri, Cours élémentaire de Droit civil (10 edición, París, Dalloz, 1948), II.

Corominas, Joan - Pascual, José A., Diccionario critico etimológico castellano e hispánico (Madrid, Gredos, 2002), V.

Corral Talciani, Hernán, Contratos y daños por incumplimiento. Estudios sobre su régimen jurídico y la responsabilidad por incumplimiento (Santiago, Abeledo Perrot - Legal Publishing, 2010).

Cristóbal Montes, Ángel, Cumplimiento e incumplimiento contractual en el Código Civil. Una perspectiva más realista, en Revista Chilena de Derecho, 34 (2007) 1.

Cristóbal Montes, Ángel, El pago o cumplimiento de las obligaciones (Madrid, Tecnos, 1986).

D’ors, Álvaro y otros (traductores), El Digesto de Justiniano (Pamplona, Aranzadi, 1968-1975).

Del Olmo García, Pedro, Los limites al pago de tercero y la legitimación para consignar, en Anuario de Derecho Civil, 52 (1999) 1.

Del Olmo García, Pedro, Pago de tercero y subrogación (Madrid, Civitas, 1998).

Demolombe, Jean Charles Florent, Cours de Code Napoléon (Paris, Imprimerie Générale, 1872), XXVII.

Di Majo, Adolfo, Adempimento in generale, en Galgano, Francesco (director), Commentario del Codice Civile, Scialoja-Branca (articulo 1177-1200) (Bolonia - Roma, Zanichelli, 1994).

Díez-Picazo, Luis, Fundamentos del Derecho civil patrimonial, II: Las relaciones obligatorias ( $6^{a}$ edición, Madrid, Thomson-Civitas, 2008).

Escala Barros, Enrique, Bello y el Código Civil chileno. Comentarios acerca de la obra 'Don Andrés Bello' de Eugenio Orrego Vicuña, en Cuadernos Jurídicos y Sociales. Universidad de Chile (s/f), III.

Feliú Rey, Manuel Ignacio, Fianza Real, subrogación por pago de tercero interesado y solidaridad no uniforme, en La Ley, 7 (2001).

FERnÁNDEZ Villa, José, El pago con subrogación: revisión del artículo 1.212 del Código Civil Español (Granada, Comares, 1999).

Friedmann, Daniel - Cohen, Nili, Payment of Another's Debt, en Drobnig, U. ZWEIGERT, K. (editores responsables), International Enciclopedia of Comparative Law (Tubinga, J.C.B. Mohr, 1991), X. 
Fueyo LaNeri, Fernando, Cumplimiento e incumplimiento de las obligaciones ( $3^{\text {a }}$ edición actualizada, Santiago, Editorial Jurídica de Chile, 2004).

Gatica Pacheco, Sergio, Aspectos de la indemnización deperjuicios por incumplimiento del contrato (Santiago, Editorial Jurídica de Chile, 1959).

GIORGIANNI, Michele, La obligación. La parte general de las obligaciones (trad. VERDERA Y Tuells, Evelio, Barcelona, Bosch Casa Editorial, 1958).

Gómez-Blanes, Pablo, La condictio de regreso porpago de tercero, en Revista Critica de Derecho Inmobiliario, 716 (noviembre-diciembre de 2009).

GuZMÁN BRITO, Alejandro, Identidad de funciones o efectos provenientes de la negocialidad entre vivos y por causa de muerte, en Revista de Derecho de la Pontificia Universidad Católica de Valparaíso, 32 (2009).

Hernández Moreno, Alfonso, El pago del tercero (Barcelona, Bosch, Casa Editorial, 1983).

HernándeZ-Gil, Antonio, Derecho de obligaciones (Madrid, Maribel Artes Gráficas, 1960).

Josserand, Louis, Derecho civil. Teoría general de las obligaciones (trad. Cunchillos y Manterola, S., Buenos Aires, Bosch, 1952), II, 1.

Lacruz Berdejo, José Luis, Elementos de Derecho civil ( $3^{a}$ edición, Barcelona, Bosch, 1994), II, 1.

Laithier, Yves-Marie, The Enforcement of Contractual Obligations: a French Pespective, en Cartwright, John - Vogenauer, Stefan - WhitTaker, Simon (editores), Reforming the French Law of Obligations. Comparative Reflections on the Avant-Projet de réforme du droit des obligations et de la prescription ('the Avant-projet Catala') (Portland, Hart Publishing, 2009).

Lamarca Marquès, Albert, (traductor y director), Código Civil Alemán y Ley de introducción al Código Civil (Madrid, Marcial Pons, 2008).

Larraín Ríos, Hernán, Teoría general de las obligaciones (Santiago, LexisNexis, 2002).

LARroumet, Christian, Teoria general del contrato (trad. Guerrero R., Jorge, Bogotá, Temis, 1999), II.

Lasarte, Carlos, Derecho de obligaciones. Principios de Derecho civil (Madrid, Marcial Pons, 2007), II.

Ledermann Rodríguez, Ricardo, De la subrogación legal en beneficio del que habiendo comprado un inmueble, es obligado a pagar a los acreedores a quienes el inmueble está hipotecado, en Revista de Derecho y Jurisprudencia, 26 (1929).

López SANTA MARÍA, Jorge, Las cadenas de contratos o contratos coligados, en Revista de Derecho de la Pontificia Universidad Católica de Valparaíso, 19 (1998).

Macgregor, Laura J. - Whitty, Niall R., Payment of Another's Debt, Unjustified Enrichment and ad hoc Agency, en Edinburgh Law Review, 15 (2011) 1.

Meza Barros, Ramón, Manual de Derecho civil. Delas obligaciones $\left(10^{\mathrm{a}} \mathrm{ed}\right.$. actualizada, Santiago, Editorial Jurídica de Chile, 2007).

Nicolò, Rosario, L'adempimento dell obbligo altrui (Milano, Giuffrè, 1936).

ОвRеснт H., Raúl, La contradicción entre los artículos 1574 y 2291 del Código Civiles sólo aparente, en Revista de Derecho y Jurisprudencia, 39 (1942), Derecho.

Palmero, Juan Carlos, El cumplimiento por el tercero (Buenos Aires, Ediciones Depalma, 1973).

Pascual Estevill, Luis, Elpago (Barcelona, Bosch, 1986). 
Peñailillo Arévalo, Daniel, Obligaciones. Teoria generaly clasificaciones. La resolución por incumplimiento (Santiago, Editorial Jurídica de Chile, 2003).

Pizarro Wilson, Carlos, El efecto relativo de los contratos: partes y terceros, en GuzMÁn Brito, Alejandro (editor científico), El Código Civil de Chile (1855-2005) (Santiago, LexisNexis, 2007).

Planiol, Marcel - Ripert, Georges J., Tratado práctico de Derecho civil francés. Las obligaciones (trad. M. Díaz Cruz y E. Le Riverend Brusone, La Habana, Cultural, 1945), VII, 2.

Pothier, Robert Joseph, Tratado de las obligaciones (s/trad., Barcelona, Imprenta y Litografía de J. Roger, 1839).

Puig Peña, Federico, Tratado de Derecho civil español (Madrid, Ed. Revista de Derecho Privado, 1946), IV, 1.

Radbruch, Gustav, Filosofía del Derecho (trad. J. Medina Echevarría, Granada, Comares, 1999).

Ramos Pazos, René, De las obligaciones ( $3^{\mathrm{a}}$ ed. revisada y corregida, Santiago, Legal Publishing Chile, 2008).

Reyes López, María José, Algunas consideraciones sobre los artículos 1.838 y 1.839 del Código civil, en Anuario de Derecho Civil, 41 (1988), 1.

Reyes López, María José, Fianza y nuevas modalidades de garantía. Análisis critico de sus elementos y efectos. Comentarios y jurisprudencia (Valencia, Editorial General de Derecho, 1996).

Rotondi, Mario, Instituciones de Derecho privado (trad. F. Fernández, Barcelona, Labor, 1953).

Rubio GARRIDO, Tomás, La subrogación porpago. Régimen jurídico y supuestos prácticos de aplicación (Madrid, McGraw-Hill, 1997).

Salas Murillo, Sofía, El cumplimiento del contrato en el anteproyecto de Código Europeo de Contratos, en Revista de Derecho Privado, 89 (2005) mes $5^{\circ}$.

Sancho Rebullida, Francisco, Comentarios al Código Civily Compilaciones Forales (2a edición, Madrid, Edersa, 1991), 16, 1.

Serra Callejo, Javier, Consideraciones sobre los efectos del pago de tercero, en Diario La Ley, 2 (1991).

Somarriva Undurraga, Manuel, Tratado de las cauciones (2a edición, Santiago, Contable Chilena, 1981).

Stitchinin Branover, David, Derecho civil (Santiago, Editorial Universitaria S.A., 1948).

VIAL Del Río, Víctor, Manual de las obligaciones en el Código Civil chileno (2a edición, Santiago, Editorial Biblioteca Americana, 2007).

Vidal Olivares, Álvaro, La construcción de la regla contractual en el Derecho civil de los contratos, en Revista de Derecho de la Pontificia Universidad Católica de Valparaiso, 21 (2000).

Vodanovic H., Antonio, La fianza (2a edición, Santiago, LexisNexis, 2004). 
